
Útmutató könyvtáralapításhoz: esettanulmány a Nemzeti Cirkuszművészeti Központ Könyvtáráról 


\section{Útmutató könyvtáralapításhoz:}

\section{esettanulmány a Nemzeti Cirkuszmủvészeti Központ \\ Könyvtáráról}

Szerkesztette

KISZl PÉTER

Eötvös Loránd Tudományegyetem Bölcsészettudományi Kar

Könyvtár- és Információtudományi Intézet

Budapest, 2021 
Útmutató könyvtáralapításhoz:

esettanulmány a Nemzeti Cirkuszművészeti Központ Könyvtáráról

Szerkesztette: Kiszl Péter

A fejezeteket írták: Kiszl Péter, Németh Katalin, Radó Rita, Senkei-Kis Zoltán

Konzulens: Juhász Éva (Nemzeti Cirkuszművészeti Központ)

Lektorálta: Tószegi Zsuzsanna

Műszaki szerkesztő: Szabó Panna

A kézirat lezárva: 2021. január 15.

A kötet az Emberi Erőforrások Minisztériuma által támogatott „Közremüködés a Nemzeti Cirkuszművészeti Központ könyvtárának, adattárának és információs központjának létrehozásában" program keretében jelent meg.

Kiadó:

Eötvös Loránd Tudományegyetem

Bölcsészettudományi Kar

Könyvtár- és Információtudományi Intézet

http://lis.elte.hu, lis@btk.elte.hu

Budapest, 2021

Nyomtatás:

CC Printing Kft.

Budapest

ISBN 978-963-489-319-6

DOI: https://doi.org/10.21862/utm_kvta_1
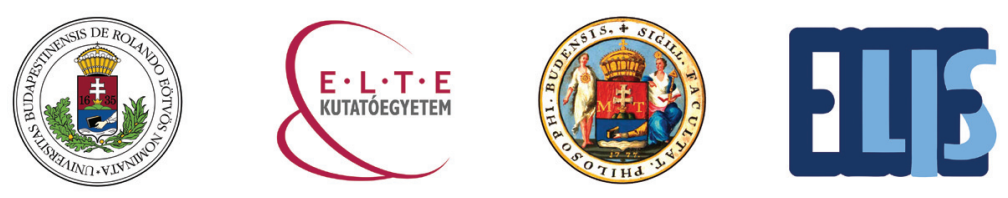


\section{TARTALOM}

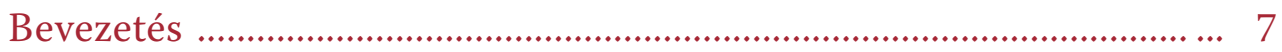

A dokumentum célja ................................................................... 8

Az útmutató tartalma ................................................................. 9

A sokszínű könyvtári rendszer (Németh Katalin) ........................................ 11

Könyvtártípusok és feladataik ......................................................... 12

Alapdokumentumok, első lépések .................................................. 22

Ellenőrző kérdések, feladatok ........................................................... 25

Ajánlott irodalom.................................................................................... 26

Dokumentumtipológia (Németh Katalin) .................................................... 29

Dokumentumtípusok, információhordozók ........................................ 30

Dokumentumtípusok, információtartalom ........................................ 37

Ellenőrző kérdések, feladatok ................................................................... 40

Ajánlott irodalom ..................................................................................... 41

Könyvtári szolgáltatások (Németh Katalin) ............................................... 43

A szolgáltató könyvtár ........................................................................ 43

Ellenőrző kérdések, feladatok ............................................................. 48

Ajánlott irodalom ....................................................................................... 49

Digitalizálási projekt tervezése (Radó Rita) .............................................. 52

Könyvtári digitalizálás .......................................................................... 52

Stratégiai környezet .......................................................................... 53

Európai uniós stratégiai dokumentumok ............................................ 54

Magyarországi stratégiai dokumentumok ................................... 57 
A digitalizálás fogalma ........................................................................ 61

A könyvtári digitalizálás iránymutató dokumentumai .................... 61

A könyvtári digitalizálás célja .............................................................. 62

A digitalizálás stratégiai elvei .............................................................. 63

A digitalizálandó dokumentum kiválasztásának szempontjai ......... 65

Ellenőrző kérdések, feladatok ................................................................. 70

Ajánlott irodalom ..................................................................................

Esettanulmány (Kiszl Péter, Németh Katalin, Radó Rita) ............................ 73

Előzmények és a projekt célja .................................................................... 73

A Nemzeti Cirkuszmüvészeti Központ a könyvtári porondon ....... 80

A Nemzeti Cirkuszművészeti Központ Könyvtárának állományi

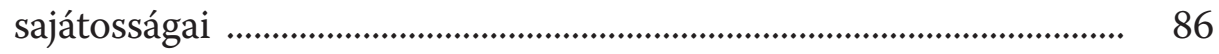

A könyvtár gyüjtőköre ........................................................................ 87

A Nemzeti Cirkuszművészeti Központ Könyvtára és a digitalizálás ................................................................................... 96

Útmutató a szakmai gyakorlatokhoz (Senkei-Kis Zoltán) ............................ 99 


\section{BEVEZETÉS}

Az évezredes múltra visszatekintő könyvtárak azért képesek a mai napig az emberiség írott kulturális örökségének megőrzéséről és hozzáférhetővé tételéről gondoskodni, mert a mindenkori társadalmi igényeknek megfelelően fogalmazzák meg küldetésüket, illetve folyamatos önreflexióval alakítják, bővítik szolgáltatásrendszerüket. Napjainkban egyre összetettebb feladatok hárulnak a legszélesebb társadalmi rétegeket szolgáló memóriaintézményekre, a könyvtárakra, amelyeknek a folyamatos változásokhoz való alkalmazkodóképessége, állandó megújulása képzett könyvtárosok nélkül elképzelhetetlen.

Ritkán kerül egy szakember abba a helyzetbe, hogy részt vehessen egy új könyvtár alapításában, de - mint az esettanulmányból látható van, aki ezzel a komoly kihívást jelentő feladattal szembesül. Jelen kiadvánnyal az Eötvös Loránd Tudományegyetem Könyvtár- és Információtudományi Intézetének oktatóiként a Nemzeti Cirkuszmüvészeti Központ könyvtáralapitását támogatjuk szakmai együttmüködésünk keretében, egyúttal a könyvtárosképzésben tankönyvként is használható módszertani kiadványt készitettünk. Összeállításunkban számba vesszük az időrendben első, a Nemzeti Cirkuszművészeti Központban manapság folyó tevékenységekhez illeszkedő szakmai feladatokat, valamint felsoroljuk a könyvtárak létének alapvető aspektusait, idézzük a vonatkozó jogszabályokat és normatív elöírásokat. Kötetünkben a könyvtári rendszer jellemzőire, a dokumentumtipológiára, a szolgáltatások előzetes áttekintésére, a digitalizálási projektek tervezésére térünk ki külön fejezetekben, a Nemzeti Cirkuszművészeti Központ igényei szerint, könyvtáralapításának körülményeit esettanulmányban is bemutatva, a 2020/2021. tanévben már zajló hallgatói szakmai gyakorlatok háttérét is ismertetve. Tervezzük munkánk folytatását, így többek között a gyüjteményszervezés, a digitalizálás, a könyvtári menedzsment és -marketing témakörének vagy a szerzői jogi kérdéseknek részletes kifejtését. 


\section{A dokumentum célja}

Folyamatosan változó világunkban a közgyűjtemények - könyvtárak, múzeumok, levéltárak - egyrészt stabilitást jelentenek, másrészt elébe mennek a technikai és társadalmi változásoknak, vagy - szükség esetén reagálnak - azokra. Az intézmények kutatói, olvasói, látogatói többnyire jól bevált, kipróbált szolgáltatásokkal találkoznak, amikor felkeresik a közgyüjteményeket a valós vagy virtuális térben; a memóriaintézményekről kialakított véleményüket az adott közgyüjtemény szolgáltatásrendszerének színvonala határozza meg.

A könyvtárnak, mint dokumentumot és információt gyüjtő, megőrző, feltáró és szolgáltató helynek azonban ahhoz, hogy a felhasználók legszélesebb köre által elérhető intézmény legyen, számos szempontot kell figyelembe vennie. Mindez igaz akkor is, ha egy új szolgáltatást kíván bevezetni, de még inkább, ha egy új épületben, a gyüjtemény alapjainak megléte nélkül kell felépítenie önmagát. Az információs társadalom alapintézménye a XXI. században is megőrizte eredeti, hagyományos funkcióját, azonban napról-napra új kihívásokkal szembesül, így gyakran új szolgáltatásokkal kell bővítenie kínálatát.

Kiadványunk célja, hogy segítséget, útmutatást nyújtson új könyvtárak alapításához, új szolgáltatások indításához. Ahhoz, hogy a könyvtár ne kényszerüljön folyamatos újratervezésre, már az első lépéseknél hosszabb távon kell gondolkodnunk. A kötet fejezeteiben - a folytatás szándékával összegyüjtöttük a hagyományos dokumentumokat tartalmazó, fizikailag felkereshetö, de az online térben is elérhető könyvtárak létesítéséhez szükséges legalapvetőbb információkat. Könyvünk célja továbbá a személyes kompetenciák fejlesztése a COVID-19 hatására mindinkább elötérbe kerülő egyéni tanulási forma biztosításával, az IKT-kompetenciáké pedig a többnyire online is elérhető szakirodalmi utalásokkal. A kötet hatékony használatát elősegíti a könyvtár- és információtudomány alapvető fogalmainak ismerete. 


\section{Az útmutató tartalma}

Különböző indok, motiváció állhat amögött, ha egy magánszemély vagy egy szervezet könyvtárat szeretne alapítani. Az új könyvtár létesítésénél gyakrabban áll elő az a helyzet, hogy már létezik egy alapgyüjtemény, amelyet bővíteni, rendezni kell - mint például egy hagyaték esetében -, azonban ilyenkor is meg kell hozni a könyvtár jellegére, típusára vonatkozó alapvető döntéseket. A kötet fejezeteiben a következő kérdéseket tárgyaljuk:

- a könyvtári rendszer elemei és a könyvtártípusok, a könyvtár felhasználói köre, hozzáférhetősége (pl. nyilvános), a könyvtár funkciója (pl. szakkönyvtár);

- a könyvtár gyűjtőköri szabályzata és a gyüjtendő dokumentumok köre: dokumentumtipológia, a dokumentum tartalma (szépirodalom, szakirodalom) és az információhordozó típusa (hagyományos papíralapú, szabad szemmel olvasható, elektronikus vagy más lejátszó eszközt igénylő stb.) alapján;

- a könyvtári szolgáltatások: a hagyományos dokumentum- és információközpontú szolgáltatásoktól a könyvtár, mint közösségi tér nyújtotta szabadidős programokon át a zöldkönyvtári szemléletig;

- digitalizálás: a digitális gyüjtemény stratégiai tervezéséhez szükséges nemzetközi és hazai iránymutatások, a koncepcionálisan átgondolt munkafolyamatokat segítő szabályzatok és tervek, továbbá a digitalizálásra szánt dokumentumok körének meghatározásakor szem előtt tartandó szempontok.

Az egyes fejezetek egymásra épülve, a szövegben többször egymásra utalva érintik az említett témákat. Mivel az egyes könyvtár- és dokumentumtípusokról, könyvtári szolgáltatásokról, valamint a digitalizálásról számos magyar nyelvü szakirodalmi forrás olvasható, így kötetünkben csak a legalapvetőbb kérdésekre kívánjuk felhívni a figyelmet. A fejezetek végén lévő kérdések és feladatok pedig a különböző szempontok továbbgondolására ösztönzik az olvasót.

Az elméleti áttekintést követően egy konkrét könyvtár példáján keresztül világítjuk meg az alapítás során felmerülő kérdéseket. A Nemzeti Artista-Elöadó- és Cirkuszmüvészeti Központ Nonprofit Kft. (rövid nevén: Nemzeti Cirkuszmüvészeti Központ Nonprofit Kft. - NCK) létrehozza 
a Közép-Európai Cirkuszmüvészeti Kutatóközpont és Adattárat, valamint a Magyar Cirkuszmüvészeti Múzeumot. ${ }^{1}$ A projekt része egy cirkuszmüvészeti szakkönyvtár alapítása, melynek gyüjtőköre, müködésének keretei kiadványunk írásakor körvonalazódnak, így esettanulmányként összegyűjtjük és bemutatjuk egy konkrét kialakítandó gyüjteménnyel kapcsolatos lehetséges kérdéseket és megoldásokat. A kötet végén pedig javaslatot teszünk az intézményben végezhető könyvtári szakmai gyakorlatok forgatókönyvére, feladataira. A könyvtárszakos hallgatók a könyvtári munkafolyamatok számos pontján hozzájárulhatnak a hatékony munkavégzéshez, így miközben megismerik a szervezet működését, kölcsönösen előnyös együttmüködés keretében segíthetnek a feladatok ellátásában.

Egy-egy téma részletesebb megismeréséhez javasoljuk tehát a fejezetek lábjegyzeteiben, valamint az egyes fejezetek végén az Ajánlott irodalomban található források tanulmányozását. A hivatkozott dokumentumok szinte teljes köre online hozzáférhető. A tanulmányok, cikkek irodalomjegyzékét érdemes átolvasni, így az ún. hólabda-módszer segítségével további releváns forrásokat találhatunk.

A jogszabályok szövegének 2021 elején hatályos változatát idézzük. Nyomatékosan felhívjuk a figyelmet, hogy minden esetben az adott időpillanatban érvényes verziót kell mérvadónak tekinteni.

A kötetben található valamennyi online forrást a kézirat lezárása előtt, 2021. január 15-én ellenőriztük, a megtekintés, illetve a letöltés dátumát nem jelöltük az egyes forrásoknál.

Az elméleti fejezetek végén olvasható Ellenőrző kérdések alfejezet az adott témakörhöz kapcsolódó feladatokkal, kérdésekkel kívánja elmélyíteni az ismereteket. Aki elvégzi a felsorolt feladatokat, valamint átgondolja és megválaszolja a kérdéseket, további szempontokat kap a könyvtárak világának megismeréséhez és a könyvtáralapítás során felteendő és megválaszolandó kérdésekhez.

\footnotetext{
${ }^{1}$ A Nemzeti Cirkuszművészeti Központ Nonprofit Kft. alapító okirata alapján. Forrás: https://nemzeticirkuszmuveszetikozpont.hu/wp-content/uploads/2020/10/alapitookirat.pdf
} 


\section{A SOKSZÍNÜ KÖNYVTÁRI RENDSZER}

A magyar szaknyelvben közkönyvtár, közművelődési könyvtár, nyilvános könyvtár néven is emlegetett public library intézménye a polgári demokráciák fejlődésével párhuzamosan alakult ki, először az angolszász országokban, majd néhány fejlett nyugat-európai országban, később az egész világon. A közkönyvtár fö célja közvetve az egész társadalom, ténylegesen egy adott közösség szolgálata. A magyar nyelvben leginkább a nem hivatalos 'közkönyvtár' megnevezés fejezi ki a klasszikus public library fogalmát, ezért az alábbiakban gyakran használjuk ezt a kifejezést - tudván tudva, hogy a vonatkozó törvény szövegében a „nyilvános könyvtár” és a „települési könyvtár" kifejezések szerepelnek. E két terminus technicus leggyakrabban együttesen vonatkozik a közkönyvtárakra.

A közkönyvtár (public library) a Könyvtári Egyesületek és Szervezetek Nemzetközi Szövetsége (International Federation of Library Associations and Institutions) és az Egyesült Nemzetek Nevelésügyi, Tudományos és Kulturális Szervezete (United Nations Educational, Scientific and Cultural Organization - IFLA/UNESCO) 1994-es közös nyilatkozata alapján „a tudáshoz vezető út helyi kapuja az egyének és a társadalmi csoportok számára az élethosszig tartó tanulás, az önálló döntéshozatal és a kulturális fejlödés alapvető feltétele."2 Ahogy elnevezése is tükrözi, a közösség által létrehozott, támogatott és finanszírozott intézmény, melynek fenntartója jellemzően valamely önkormányzat, vagy maga az állam. A közkönyvtárak hozzáférést biztosítanak az információhoz, elősegítik az élethosszig tartó tanulást egyenlően minden ember számára nemzetiségtől, életkortól, nemtől, vallástól, anyanyelvtől, gazdasági és foglalkoztatási helyzettől, valamint iskolai végzettségtől függetlenül. A társadalmi igényeknek megfelelően a modern közkönyvtár a gyűjteménycentrikus szerepből mindenki számára nyitott, élményt nyújtó, szolgáltatásközpontú hellyé változik, közösségi együttlétre és kreativitásra alkalmas, flexibilisen alakítható terekkel rendelkezik.

${ }^{2}$ GILL, Philip [et al.]: A közkönyvtári szolgálat. Az IFLA és az UNESCO közös fejlesztési irányelvei. Ford. Papp István. Budapest, Könyvtári Intézet, 2005. 15. p. Forrás: https:// www.ifla.org/files/assets/hq/publications/archive/the-public-library-service/pg01-hu.pdf 
A könyvtárak az informatikai és technológiai változások mentén folyamatosan megújulnak mind gyüjteményük, mind szolgáltatásaik tekintetében. A könyvtár hagyományos definíciója szerint a dokumentumok tervszerüen gyarapitott, rendezett és feltárt, használatra szánt gyüjteménye. Sok könyvtár korlátozás nélkül, a széles felhasználói kör számára teszi elérhetővé szolgáltatásait és dokumentumait, de vannak olyan könyvtárak is, amelyeket csak egy meghatározott kör látogathat. Az 1997. évi CXL. törvény a muzeális intézményekröl, a nyilvános könyvtári ellátásról és a közmüvelődésről ${ }^{3}$ (hivatalos rövidítése: Kultv.) a hozzáférés szempontjából megkülönbözteti a nyilvános és a nem nyilvános könyvtárakat.

Az Amerikai Könyvtári Egyesület (American Library Association ALA) szerint a könyvtár a közösséggel rendszeres, aktív kapcsolatban álló intézmény, amely sokoldalúan biztosítja az információhoz való hozzáférés és a kulturális örökség megőrzése mellett a multifunkciós könyvtári közösségi teret is. A társadalmi igények és elvárások, illetve az információtechnológiai fejlődés a szolgáltatások bővítésére ösztönzik a könyvtárakat, így a fejlesztések tervezésekor nem lehet megkerülni a környezeti tényezőket, az aktuális trendek megismerését sem. Azonban nemcsak a szolgáltatások változtak, változnak: az évszázadok során a dokumentumok számának robbanásszerű emelkedése, az információhordozók sokfélesége, a digitalizálás, valamint a felhasználói csoportok igényeinek radikális változása miatt különböző könyvtártípusok és különgyüjtemények alakultak ki.

\section{Könyvtártípusok és feladataik}

A könyvtárak számos szempont szerint csoportosíthatók. Az egyes típusok között gyakran nem húzhatók éles határvonalak, és egy-egy intézmény akár több csoportba is sorolható. Magyarországon a nyilvános könyvtár alapítása törvények által szabályozott jogi aktus, így a jogszabályok mentén vesszük sorra az egyes könyvtártípusokat és azok feladatkörét.

Az 1997. évi CXL. törvény új irányvonalat adott a könyvtári rendszernek, és egyúttal definiálta a nyilvános könyvtárak alapfeladatait. An-

\footnotetext{
${ }^{3}$ 1997. évi CXL. törvény a muzeális intézményekről, a nyilvános könyvtári ellátásról és a közművelődésről. Forrás: https://net.jogtar.hu/jogszabaly?docid=99700140.TV
} 
nak érdekében, hogy az intézményrendszer képes legyen követni a társadalmi és technológiai változásokat, időről időre módosítják a Kultv. szövegét. Az alábbiakban a 2021. február 1-jétől hatályos szövegváltozat részlete olvasható: ${ }^{4}$

„55. \$ (1) A nyilvános könyvtár alapfeladatai:

a) a fenntartó által kiadott alapító okiratban és a szervezeti és működési szabályzatban meghatározott fő céljait küldetésnyilatkozatban közzé teszi, b) gyüjteményét folyamatosan fejleszti, feltárja, megőrzi, gondozza és rendelkezésre bocsátja,

c) tájékoztat a könyvtár és a nyilvános könyvtári rendszer dokumentumairól és szolgáltatásairól,

d) biztosítja más könyvtárak állományának és szolgáltatásainak elérését,

e) részt vesz a könyvtárak közötti dokumentum- és információcserében,

f) biztosítja az elektronikus könyvtári dokumentumok elérhetőségét,

g) a könyvtárhasználókat segíti a digitális írástudás, az információs műveltség elsajátításában, az egész életen át tartó tanulás folyamatában,

h) segíti az oktatásban, képzésben részt vevők információellátását, a tudományos kutatás és az adatbázisokból történő információkérés lehetőségét, i) kulturális, közösségi és egyéb könyvtári programokat szervez,

j) tudás-, információ- és kultúraközvetítő tevékenységével hozzájárul az életminőség javításához, az ország versenyképességének növeléséhez, k) a szolgáltatásait a könyvtári minőségirányítás szempontjait figyelembe véve szervezi." ${ }^{5}$

Ahogy az idézett Kultv. 55. $\$(1)$ a) pontjában látható, a fenntartónak el kell készítenie a könyvtár alapító okiratát, szervezeti és müködési szabályzatát (SZMSZ), valamint meg kell határoznia az intézmény küldetését.

A Kultv. értelmében bármely könyvtár kérheti felvételét a nyilvános könyvtárak közé, amennyiben megfelel a törvényben elöírt kritériumoknak. Ennek köszönhetően szinte valamennyi könyvtártípusból találunk

\footnotetext{
${ }^{4}$ A hatályban lévő jogszabályokról a Könyvtári Intézet rendszeresen tájékoztat. Forrás: https://www.ki.oszk.hu/informacioszolgaltatas/hatalyos-jogszabalyok

${ }^{5}$ 1997. évi CXL. törvény a muzeális intézményekről, a nyilvános könyvtári ellátásról és a közművelődésről. 55 . $\mathbb{S}(1)$ bekezdés.
} 
példát a Nyilvános Könyvtárak Jegyzékén. ${ }^{6}$ Mielőtt meghatároznánk azonban a létesítendő könyvtár típusát, tekintsük át a XXI. századi könyvtári rendszer gazdag világát. Az egyes könyvtártípusok alapfeladatai kiegészülnek a nyilvános könyvtárakkal szemben megfogalmazott alapfeladatokon túl a fenntartó vagy a szakterület egyéb elvárásaival, szempontjaival, amelyekre az alábbiakban szintén utalunk.

A kezdeti enciklopédikus gyüjtésre való törekvés, mely az első nemzeti könyvtárakat, mint például a francia Bibliothèque nationale-t vagy az angol The British Library-t jellemezte, a tudományok fejlödésével és a kiadványok számának robbanásszerü emelkedésével tarthatatlanná vált. A XX. század második felére végül elsődleges feladatként a nemzeti irodalom gyüjtése körvonalazódott, melynek köszönhetően a kulturális örökség része a nemzeti könyvtár állománya.

A Kultv. 55. \$-ában foglaltakon túl a nemzeti könyvtár alapfeladatai a következők:

„Magyarországon keletkezett kiadványok kötelespéldány-szolgáltatásra alapozott gyűjtése, megőrzése, szétosztása,

b) a külföldön megjelent hungarikumok teljességre törekvő gyüjtése, feltárása, megőrzése,

c) a kiadványnak nem minősülő hungarikumok gyüjtése, feltárása, megőrzése,

d) a nemzeti bibliográfia készítése,

e) gyüjteményének archiválása és védelme,

f) gyüjteményének elsősorban helyben használat útján történő rendelkezésre bocsátása,

g) tevékenységi körébe tartozó kutatások végzése,

i) a kulturális örökség részét képező könyvtári dokumentumok és könyvtárak védetté nyilvánításával, nyilvántartásával és külföldre vitelének engedélyezésével kapcsolatos, a kulturális örökség védelmével kapcsolatos jogszabályokban meghatározott feladatok ellátása,

j) könyvtári dokumentumokról hitelesített másolatok készítése."7

\footnotetext{
${ }^{6}$ Nyilvános Könyvtárak Jegyzéke. Forrás: https://www.ki.oszk.hu/informacioszolgaltatas/ nyilvanos-konyvtarak-jegyzeke

${ }^{7}$ 1997. évi CXL. törvény 61. \$
} 
A jogalkotó 2021-től a nemzeti könyvtár feladatkörébe utalta a webarchiválást - amelyre az alábbiakban még visszatérünk.

A patriotikumok, hazai vonatkozásban hungarikumok négy csoportját különbözteti meg a magyar nemzeti könyvtár, az Országos Széchényi Könyvtár (OSZK), valamint a törvény szövegével összhangban az OSZKban készülő nemzeti bibliográfia:

1. területi: Magyarország mindenkori államigazgatási határain belül keletkezett dokumentumok,

2. nyelvi: magyar nyelven megjelent dokumentumok,

3. személyi: magyar, illetve magyarországi szerző által írt dokumentumok,

4. tartalmi: magyar, illetve magyarországi témát bemutató dokumentumok. ${ }^{8}$

A területi hungarikumok gyüjtését a rendeletileg elöírt ún. kötelespéldányszolgáltatás teszi lehetővé. A hatályos kormányrendelet azonban a kiadványok kötelespéldányainak szolgáltatása mellett azok megőrzésére és használatára vonatkozó szabályokat is előír; meghatározza a kötelespéldányok szolgáltatására kötelezett, illetve a kötelespéldányokra jogosultak körét. A rendelet hatálya nemcsak a nyomtatott, hanem az elektronikus formában megjelenő könyvekre, időszaki kiadványokra, térképekre, továbbá az online elektronikus kiadványokra, a videotermékekre stb. is kiterjed. Részletes szabályok szólnak arról, mely dokumentumtípusból hány példányt kell a kötelespéldány-szolgáltatásra kötelezett szervezeteknek a kijelölt intézmények számára eljuttatniuk. A kötelespéldányból részesülő intézmények között nemcsak könyvtárak vannak. A könyvtárakra nézve a rendelet továbbá elöírja az Országos Dokumentumellátási Rendszerben (ODR) nyújtandó szolgáltatási kötelezettségeket is. ${ }^{9}$

A patriotikumok gyüjtése a hagyományos dokumentumok vonatkozásában, főként a tartalmi hungarikumok esetében sem mindig egyszerü, azonban a XXI. században egyre jobban bővül a feldolgozandó dokumentumok köre. Az analóg hordozók mellett a kizárólag online módon, a há-

\footnotetext{
${ }^{8}$ Magyar Nemzeti Bibliográfia. Forrás: https://mnb.oszk.hu

${ }^{9} 717 / 2020$. (XII. 30.) Korm. rendeleta kiadványok kötelespéldányainak szolgáltatásáról, megörzéséről és használatáról. Forrás: https://net.jogtar.hu/jogszabaly?docid=a2000717.kor és OSZK Kötelespéldány-szolgálat. Forrás: http://www.oszk.hu/kotelespeldanyok?mobile=off
} 
lózaton közzétett, digitális kódolású források begyüjtése is megkezdődött. Ezt a feladatot a Kultv. 59/A. \$-a (1) pontja 2021. január 1-jétől kezdve írja elő az OSZK számára: „A webtartalom archiválás keretében, webaratással történő begyűjtésének, feldolgozásának, másolásának, hosszú távú megőrzésének és webarchívumba rendezésének, továbbá felhasználásának feladatát (a továbbiakban együtt: webarchiválás) a nemzeti könyvtár látja el."10

Visszatérve a magyar könyvtári rendszer rövid bemutatásához: a lakosság túlnyomó része számára az ún. települési könyvtárak által nyújtott szolgáltatások érhetők el szerte az országban. E könyvtárak feladatait a Kultv. így határozza meg:

„65. $\$(1)$ A települési könyvtár a községi, városi, fővárosi könyvtár.

(2) A települési könyvtár az 55. $\mathbb{S}$ (1) bekezdésében foglaltakon túl

a) gyűjteményét és szolgáltatásait a helyi igényeknek megfelelően alakítja,

b) közhasznú információs szolgáltatást nyújt,

c) helyismereti információkat és dokumentumokat gyüjt,

d) szabadpolcos állományrésszel rendelkezik,

e) gyermek- és családbarát szolgáltatásokat nyújt."

A községekben és kisebb városokban a megyei hatókörű városi könyvtár szolgáltatásaival is biztosítani lehet az adott település könyvtári ellátását.

Az egyes intézmények hálózatba szervezve, egymással együttmüködve tudják igazán hatékonyan ellátni feladataikat. A könyvtári rendszer működését segítik és biztosítják a (külső) irányítás és a központilag végzett tevékenységek, a központi szolgáltatások, amelyeket a Kultv. 60. \$-a szabályoz.

A törvény a hungarikumok gyüjtése és szolgáltatása mellett nagy hangsúlyt fektet mind a nemzetiségek, mind a határon túli magyarok könyvtári ellátására, és rendelkezik az országos könyvtári informatikai hálózat fejlesztéséről és tartalmi feltöltéséről, illetve elrendeli a fentebb már említett Országos Dokumentumellátási Rendszer (ODR) működtetését.

A Kultv. a Könyvtári Intézet (KI) feladataként határozza meg az alábbi szolgáltatásokat, amelyek szintén a minél hatékonyabb rendszerműködést kívánják támogatni:

- a könyvtárakkal kapcsolatos kutatásokat végez;

\footnotetext{
${ }^{10} 1997$. évi CXL. törvény a muzeális intézményekről, a nyilvános könyvtári ellátásról és a közművelődésről. 59/A.\$-a (1) pont.
} 
- javaslatot tesz és/vagy kidolgozza a könyvtárügyre vonatkozó szabványokat;

- a könyvtári szakemberek számára továbbképzéseket és iskolarendszeren kívüli képzéseket szervez;

- vezeti a Nyilvános Könyvtárak Jegyzékét;

- koordinálja a könyvtárak minőségirányítási tevékenységét. ${ }^{11}$

A szakkönyvtárak az adott tudományterülethez kapcsolódó szakirodalom gyűjtésére és szolgáltatására vállalkoznak az információhordozó típusától függetlenül. A Kultv. 63. \$-a alapján:

„(4) Az országos szakkönyvtárak és az állami egyetemek könyvtárainak alapfeladatai az 55. $\mathbb{S}(1)$ bekezdésében meghatározottakon túl

a) szakterületükön szakirodalmi és információs szolgáltatásokat végeznek, és közvetítenek,

b) szakterületükre vonatkozóan részt vesznek a 60 . \$-ban felsorolt szolgáltatások megvalósításában."

A szakkönyvtárak támogatják továbbá az innovációs tevékenységet, a tudományos kutatást, valamint a felsőoktatást. Számos szakkönyvtár a nyomtatott dokumentumokkal szemben az online tartalmak beszerzését részesíti előnyben, ennek egyik költséghatékony módja akár az országhatáron átívelő konzorciumi együttmüködés.

A felsőoktatási könyvtárak különleges szerepet töltenek be a könyvtárak között: az oktatók, kutatók munkáját értékes szakirodalmi források szolgáltatásával segítik, amivel a színvonalas oktatás mellett a hazai és a nemzetközi tudományos életbe való bekapcsolódásukhoz is hozzájárulnak. A felsőoktatásban tanuló hallgatók a legaktívabb könyvtárhasználói réteget jelentik, akik saját oktatási intézményük mellett a nemzeti könyvtár és a szakkönyvtári hálózat szolgáltatásait is igénybe veszik. Számos egyetemi könyvtárra jellemző még mindig a tagolt, elaprózott tanszéki, intézeti struktúra, amit a könyvtárosok igyekeznek például az egységes integrált könyvtári rendszerek használatával összekötni. A 2018-2023-as időszakra

\footnotetext{
${ }^{11}$ A Könyvtári Intézet feladatairól, szerepéről a Kultv. 60 \$ (3) pontja mellett a 6/2000. (III. 24.) NKÖM rendelet tájékoztat a Könyvtári Intézet jogállásáról. Forrás: https://net.jogtar. hu/jogszabaly?docid=99700140.tv
} 
megfogalmazott stratégiai fejlesztési irányok ${ }^{12}$ között szerepel a gyüjteményekhez való hozzáférés megkönnyítése, a kutatás- és a tanulástámogatás hangsúlyosabbá tétele. Az egyetemi könyvtárak aktív szerepet vállalnak a felsőoktatási intézmények kutatás-fejlesztési projektjeiben, mivel képesek inspirálni és költséghatékonyabbá tenni azokat.

A nemzeti felsőoktatási törvény hangsúlyozza a könyvtári szolgáltatás szükségességét, valamint a nyilvános könyvtárakra vonatkozó törvénnyel összhangban rendelkezik az alapfeladatokról:

„11. $\mathbb{S}(2)$ A felsőoktatási intézménynek az alaptevékenységéhez igazodóan biztosítania kell egészségfejlesztést is beleértve a rendszeres testmozgás és sporttevékenység megszervezését, a könyvtári szolgáltatást, a tudásalapú gazdasághoz kapcsolódó pénzügyi- és vállalkozói-, az anyanyelvi, szaknyelvi ismeretek fejlesztését, lehetőséget kell teremtenie az idegen nyelvi szaknyelvi ismeretek fejlesztésére."

A törvény részletesen szól a felsőoktatási könyvtárak feladatairól: „14. $\mathbb{S}(2)$ A felsőoktatási intézmény könyvtára, könyvtári rendszere szakirodalmi, információs, oktatási és kutatási feladatokat ellátó nyilvános tudományos közgyüjtemény, amely muzeális intézményi, levéltári funkciót is elláthat. Az állami egyetemi könyvtárak biztosítják a hagyományos és virtuális tanulási környezetet, a tananyagok és a szakirodalom elérhetöségét, tudománymetriai szolgáltatásokat nyújtanak, ellátják az intézmény tartalomgazdai feladatait, továbbá a muzeális intézményekről, a nyilvános könyvtári ellátásról, és a közművelődésről szóló törvényben meghatározott nyilvános könyvtári, valamint szak- és felsőoktatási könyvtári feladatokat. Az egyetemi könyvtárak az Országos Dokumentum-ellátási Rendszerből - jogszabályban meghatározottak szerint - támogatást kapnak."13

Az iskolai könyvtár fogalma és feladatköre az évszázadok alatt jelentősen megváltozott és kibővült, ahogy azt az IFLA meghatározásában olvashatjuk: az iskolai könyvtár - más néven iskolai médiaközpont, dokumentációs és információs központ, könyvtári forrásközpont stb. - fizikai és

\footnotetext{
${ }^{12}$ A felsőoktatási könyvtárak stratégiai fejlesztési irányai, 2018-2023. Forrás: https://ekk. org.hu/wp-content/uploads/2020/08/EKFJ_2018_2023a.pdf

${ }^{13} 2011$. évi CCIV. törvény a nemzeti felsőoktatásról. Forrás: https://net.jogtar.hu/jogszabaly?docid=a1100204.tv\&timeshift=20210201
} 
digitális tanulási hely, „ahol az olvasás, kérdezés, kutatás, gondolkodás, képzelőerő és a kreativitás központi fontosságú a diákoknak az információktól a tudásig tartó „utazásához” és a személyes, társadalmi és kulturális fejlödéséhez." ${ }^{14}$

A 2011. évi CXC. törvény a nemzeti köznevelésről (Köznev. tv.) elismeri a tanulók jogát ahhoz, hogy igénybe vegyék az iskolai könyvtár, valamint a kollégiumi könyvtár szolgáltatásait. ${ }^{15}$ Az iskolai könyvtárakra a köznevelési intézmények részeként minden, az oktatási intézményekkel kapcsolatos jogszabály egyaránt vonatkozik. ${ }^{16}$ Magyarországon az utóbbi időben főként kistelepüléseken nem ritka az ún. integrált könyvtárak müködése, a különböző típusú intézmények összevonása.

A könyvtárostanár feladata a köznevelési törvény alapján: „62. \$ (12) Az iskolai, kollégiumi könyvtárostanár, könyvtárostanító a neveléssel-oktatással lekötött munkaidő keretében biztosítja a könyvtár nyitva tartását, a könyvtári órákat. Munkaköri feladatként a kötött munkaidő többi része hetven százaléka - a könyvtár zárva tartása mellett - a munkahelyen végzett könyvtári munkára (az állomány gyarapítása, gondozása, könyvtári kutatómunka), iskolai kapcsolattartásra, a további harminc százaléka a munkahelyen kívül végzett felkészülésre, könyvtári kapcsolatépítésre, állománygyarapításra, továbbá a pedagógus-munkakörrel összefüggő más tevékenység ellátására szolgál."

A törvény a pedagógusok könyvtárhasználati jogáról is rendelkezik: „63. $\mathbb{S}(1)$ A pedagógust munkakörével összefüggésben megilleti az a jog, hogy

i) az iskola könyvtárán keresztül használatra megkapja a munkájához szükséges tankönyveket, tanári segédkönyveket, az intézmény SZMSZ-ében meghatározottak szerinti informatikai eszközöket."17

\footnotetext{
${ }^{14}$ IFLA Iskolai Könyvtári Szekciójának Állandó Bizottsága: IFLA Iskolai könyvtári útmutató. 2. átdolg. kiad. Ford. Bognárné Lovász Katalin. Budapest, Könyvtárostanárok Egyesülete, 2016. Forrás: https://www.ifla.org/files/assets/school-libraries-resource-centers/ publications/ifla-school-library-guidelines-hu.pdf

15 2011. évi CXC. törvény a nemzeti köznevelésről. Forrás: https://net.jogtar.hu/jogszabaly?docid=a1100190.tv

${ }_{16} \mathrm{Az}$ iskolai könyvtárakat érintő jogszabályok. Forrás: https://www.opkm.hu/?lap= konyvtar/szakfel

${ }^{17}$ 2011. évi CXC. törvény a nemzeti köznevelésről. 63. \$.
} 
Az információhoz való hozzáférés mellett kiemelt szerepet kap a könyvtárak feladatkörében az információ értékelése és alkalmazása, az információs eszközök és források kiválasztása, amely képességek hozzájárulnak az élethosszig tartó tanuláshoz. A könyvtárak így válnak oktató intézménnyé, köztük elsősorban az iskolai könyvtár feladata az információs műveltség fejlesztése. A 20/2012. (VIII. 31.) EMMI-rendelet a nevelési-oktatási intézmények müködéséről és a köznevelési intézmények névhasználatáról az iskolai könyvtárak számára lehetővé teszi az alapfeladatuk mellett a nyilvános könyvtári feladatok ellátását is, összhangban a kulturális törvénnyel, ahogy a települési könyvtár is betölthet iskolai könyvtári funkciót. A minisztériumi rendelet vonatkozó fejezete így szól:

„164.\$ (1) Az iskolai, kollégiumi könyvtár nyilvános könyvtári feladatokat is elláthat, ha azt a könyvtárat müködtető iskola, kollégium alapító okirata, szakmai alapdokumentuma lehetővé teszi, továbbá az iskola, kollégium vezetőjének kezdeményezésére bejegyezték a nyilvános könyvtárak jegyzékébe.

(2) A nyilvános könyvtár iskolai, kollégiumi könyvtár feladatait is elláthatja, ha e tevékenységre az alapító okirata, szakmai alapdokumentuma feljogosítja, továbbá iskolai, kollégiumi könyvtárostanárt, könyvtárostanítót alkalmaz, és megfelel az e rendeletben meghatározott követelményeknek." ${ }^{18}$

Az egyházi könyvtárak fenntartója valamely felekezet, mely kötődés a gyüjtőkörüket is meghatározza. Az egyházi gyüjtemények állománya - részben vagy egészben - nemzeti kulturális örökségünk legértékesebb részéhez tartozik, ahogy számos, e könyvtáraknak otthont adó épület is becses műemlékeink sorát gyarapítja. Az egyház és az állam, az egyház és a művészet évszázadokon keresztül együtt élt Magyarországon, így az egyházi gyüjtemények állományának változásai szemléltetik az ország sorsát is. Egyházi jellegükből adódóan e könyvtárak gyüjtőköre lényegében hasonló, mivel elsősorban teológiai szakirodalmat gyüjtenek, azonban a teológia, a vallási vagy vallásos irodalom között nehéz megrajzolni a pontos határt. A vallásos irodalom elsősorban a hívekhez szól, míg a teológia az objektív igazságot próbálja meg tudományosan megfogalmazni. A hittudománnyal

\footnotetext{
${ }^{18}$ 20/2012. (VIII. 31.) EMMI rendelet a nevelési-oktatási intézmények működéséről és a köznevelési intézmények névhasználatáról. Forrás: https://net.jogtar.hu/jogszabaly? docid=a1200020.emm
} 
kapcsolatos dokumentumok mellett jogtudományi, filozófiai, orvos-, valamint társadalomtudományi müvek is megtalálhatók az egyházi könyvtárak állományában. Fő profiljuk szerint általában egy meghatározott területen tudományos, információs és továbbképzési központként is szolgálnak. A Kultv. lehetővé tette, hogy az egyházi könyvtárak is kérhetik felvételüket a nyilvános könyvtárak jegyzékébe, így számos könyvtár vált elérhetővé a szélesebb közönség számára. Mivel alapvetően a fenntartó miatt beszélhetünk egyházi gyüjteményekről, így a szerzetesi vagy plébániai könyvtárak mellett idetartozhatnak a felekezeti fenntartású iskolák és felsőoktatási intézmények könyvtárai is (például a Piarista Rend Magyar Tartománya Központi Könyvtára, az Evangélikus Hittudományi Egyetem könyvtára).

Hozzáférés szempontjából is csoportosíthatjuk a könyvtárakat. A nem nyilvános könyvtárak közé tartoznak azok a gyüjtemények, amelynek szolgáltatásait csak az adott könyvtár alapító okiratában meghatározott kör veheti igénybe. Tipikus példák a vállalati könyvtárak, az államigazgatási szervek, kutatóintézetek stb. gyüjteményei. Vannak olyan nem nyilvános könyvtárak, amelyek - a fenntartó által meghatározott engedély birtokában - külső felhasználók számára is biztosítják a gyüjtemény helyben használatát.

A Könyvtári Intézet honlapján a Magyarországi Könyvtárak Adatbázisa $^{19}$ további könyvtártípusokat is megnevez, a fenntartóra tekintettel (például alapítványi könyvtár, egyesületi könyvtár, magánkönyvtár stb.), a funkcióra vagy a helyszínre (például kórházi könyvtár, műemlékkönyvtár stb.).

A XX. század végétől az internet és a digitális kultúra paradigmaváltást eredményezett. Az adatok és az információk hálózatba szervezésének, szerveződésének egyszerre eredője és eredménye a digitalizálás. Az online katalógusok, a szemantikus web, az állományvédelmi szempontok, a kulturális örökség megőrzése, a minél több felhasználó egyidejü kiszolgálása iránti igény vezetett az elektronikus és/vagy virtuális könyvtárak létrejöttéhez. Az e-könyvtárak esetében a hozzáférés módja adja az elnevezés alapját, mivel eltérő, hogy egy-egy digitális tartalmat szolgáltató intézmény mögött áll-e hagyományos, analóg dokumentumokat is gyüjtő könyvtár. A közreadott online dokumentumok köre is lehet hagyományos dokumentum digitális másolata, illetve eleve a digitális térben született, ún. born-digital dokumentum. A digitalizálásra egy önálló fejezetben még visszatérünk.

\footnotetext{
${ }^{19}$ Magyarországi Könyvtárak Adatbázisa. Forrás: https://ki.oszk.hu/informacioszolgaltatas/magyarorszagi-konyvtarak-adatbazisa
} 


\section{Alapdokumentumok, első lépések}

Könyvtáralapítás előtt számos kérdést át kell gondolnunk, és azokra választ kell adnunk - így például meg kell határoznunk az alapítandó könyvtár típusát, a felhasználói célcsoportot, a szolgáltatások körét és azok nyújtásának módját stb. Kérdésként merülhet fel, hogy meglévő dokumentumgyűjteményre építjük-e a tervezett szolgáltatásokat, vagy a létesítendő intézmény a szolgáltatni kívánt dokumentumokat csak később fogja beszerezni. A könyvtártípus, a gyüjtendő dokumentumok köre és a ráépülő, a helyi adottságokkal jól gazdálkodó szolgáltatások egyaránt hozzájárulnak a könyvtáralapítási projekt sikerességéhez.

A fenntartó (az állam, az önkormányzatok stb.) határozza meg a jogszabályi környezettel összhangban a könyvtár feladatait, valamint gondoskodik a megfelelő személyi és tárgyi feltételekről. A fenntartókra háruló kötelező feladatokról lássuk a kulturális törvény vonatkozó paragrafusát: „68. \$ (1) A fenntartó az e törvényben foglaltak alapján

a) meghatározza a könyvtár feladatait és használati szabályzatát,

b) kiadja alapító okiratát, jóváhagyja szervezeti és mủködési szabályzatát,

c) biztosítja a feladatok ellátásához szükséges személyi és tárgyi feltételeket, ennek során figyelembe veszi a miniszter által meghatározott szakmai követelményeket és normatívákat,

d) jóváhagyja a könyvtár fejlesztésére vonatkozó terv(ek)et,

e) az országos könyvtári szakértői névjegyzékben szereplő szakértők közreműködésével értékeli a könyvtár szakmai tevékenységét,

f) biztosítja a könyvtár szakmai önállóságát,

g) ellátja a könyvtár fenntartásával, irányításával kapcsolatos más jogszabályokban meghatározott feladatokat."

Első lépésként a fenntartóval közösen át kell gondolnunk az intézmény létrehozásának indokát és célját, és egyeztetni azokat a szempontokat, amelyek mentén kialakítjuk majdani gyűjteményünket, szolgáltatásainkat. A küldetésnyilatkozatban megfogalmazzuk a könyvtár átfogó célját, miszszióját a könyvtárhasználók számára. A dokumentum elkészítését a Kultv. írja elö, de ezen túlmenően a stratégiai tervek egyik kötelező eleme, valamint a minőségbiztosításnak is alapja. A küldetésnyilatkozatukat a nyilvá- 
nos könyvtáraknak közzé kell tenniük az intézmény honlapján, emellett el kell készíteniük az alapító okiratukat.

Számos könyvtár müködik költségvetési szervként, melynek definíciója az államháztartási törvény (Áht.) szerint:

„7. \$ (1) A költségvetési szerv jogszabályban vagy alapító okiratban meghatározott közfeladat ellátására létrejött jogi személy."20

Az alapító okirattal kapcsolatban az államháztartási törvény végrehajtásáról szóló rendelet (Âvr.) az Áht. 8/A. $\mathbb{S}(1)$ bekezdéséhez az alábbiakat rendeli:

„5. $\mathbb{S}(1)$ Az alapító okirat tartalmazza a költségvetési szerv

a) megnevezését magyar nyelven,

b) székhelyét, telephelyeit,

c) alapításáról rendelkező jogszabály teljes megjelölését, ha az alapításról jogszabály rendelkezett,

d) irányító szervének vagy felügyeleti szervének megnevezését, székhelyét,

e) illetékességét, működési területét,

f) közfeladatát, alaptevékenységét, ezek kormányzati funkció szerinti megjelölését és főtevékenységének államháztartási szakágazati besorolását,

g) vezetőjének megbízási rendjét, és

h) alkalmazásában álló személyek jogviszonyának megjelölését."21

A kulturális törvény által előírt kötelezettség ${ }^{22}$ továbbá a könyvtár szervezeti és működési szabályzatának (SZMSZ) elkészítése, amelynek legfontosabb elemei a következők:

- az intézmény alapadatai

○ az intézmény megnevezése

- az intézmény fenntartója

- az intézmény felügyelete

- az intézmény székhelye

- az intézmény elérhetőségei

20 2011. évi CXCV. törvény az államháztartásról. Forrás: https://net.jogtar.hu/jogszabaly?docid=a1100195.tv

${ }^{21}$ 368/2011. (XII. 31.) Korm. rendelet az államháztartásról szóló törvény végrehajtásáról. Forrás: https://net.jogtar.hu/jogszabaly?docid=a1100368.kor\&timeshift=20210115

${ }^{22}$ 1997. évi CXL. törvény 68. $\mathbb{S}(1)$ bekezdés 
○ az intézmény jogállása

○ az intézmény bélyegzője

- az intézmény közfeladatai

- az intézmény alaptevékenysége a szakfeladatrend szerint (pl. 910123 Könyvtári szolgáltatások)

- gyűjtőkör (gyűjtőköri szabályzat mellékletként)

- szervezeti felépítés

○ a könyvtár vezetése

○ a vezető kinevezési rendje

○ a szervezeti egységek és feladataik (munkaköri leírások mellékletként),

- müködés

- tervezés és gazdálkodás

- könyvtárhasználati szabályzat.

Az SZMSZ-ben tehát rögzíteni kell a munkáltatói, munkavállalói jogokat és kötelezettségeket, valamint a működésre vonatkozó szabályokat, a működési rendet. Az állományalakítással - gyarapítás és apasztás - kapcsolatos elveket (tudományterület, dokumentumtípus, példányszám stb.) a könyvtár gyűjtőköri szabályzatában tudjuk részletesen kifejteni.

A könyvtárhasználati szabályzatban az alapfeladatokon túl a beiratkozáshoz és/vagy térítési díjhoz kötött szolgáltatásokat, a nyitvatartási időt, a dokumentumkölcsönzéssel kapcsolatos információkat, valamint a könyvtárhasználókat megillető jogokat és a könyvtárhasználat feltételeit rögzítjük. Ezt a dokumentumot a könyvtár honlapján közzé kell tenni, illetve az olvasószolgálatban kinyomtatva is a könyvtárhasználók rendelkezésére kell bocsátani.

Az Európai Unió 2016. április 27-i (EU) 2016/679. sz. Általános Adatvédelmi Rendelete (General Data Protection Regulation - GDPR) kötelezően alkalmazandó 2018. május 25-től az Unió valamennyi tagállamában, így Magyarországon is. A könyvtáraknak, mint közfeladatellátó szerveknek, kötelező elkészíteniük a személyesadat-kezelési szabályzatukat, amelyet mindenki számára elérhetővé kell tenniük. A 2011. évi CXII. törvény az információs önrendelkezési jogról és az információszabadságról (Info tv.) részletesen szabályozza a személyes adat, adatkezelő, adatkezelés kérdéskörét. ${ }^{23}$

${ }^{23} 2011$. évi CXII. törvény az információs önrendelkezési jogról és az információszabadságról. Forrás: https://net.jogtar.hu/jogszabaly?docid=a1100112.tv 
A hosszú távú sikeres működés érdekében el kell készíteni a könyvtár minőségirányítási kézikönyvét, mivel a Kultv. 55.\$. (1) k) pontja kötelezi a könyvtárakat, hogy szolgáltatásaikat a minőségirányítás szempontjait figyelembe véve szervezzék. A nyilvános könyvtárak pályázhatnak a 33/2017. (XII. 12.) EMMI rendelet ${ }^{24}$ szerinti Minösitett Könyvtár címre és Könyvtári Minöségi Díjra.

A könyvtári szolgáltatások minőségével is összefüggésben áll az intézmény panaszkezelési gyakorlata, így a panaszkezelési szabályzat a látogatók, de a munkatársak számára is támpontot nyújt az egyszerü véleménynyilvánítástól a komolyabb panaszszituációk megoldásáig. A szabályzatnak tartalmaznia kell a döntésre jogosultak körét, az esetleges kompenzációkat. Az írásban benyújtott panaszt köteles a könyvtár kivizsgálni.

A könyvtár típusától és a szolgáltatásoktól függ azon jogszabályok köre, amelyeket figyelembe kell venni az alapdokumentumok elkészítésekor, valamint a működés során.

${ }^{24}$ 33/2017. (XII. 12.) EMMI rendelet a Minősített Könyvtár cím és a Könyvtári Minőségi Díj adományozásáról Forrás: https://net.jogtar.hu/jogszabaly?docid=A1700033. EMM\&celpara $=44 / 2011 \&$ goto $=-1$ 


\section{Ellenőrző kérdések, feladatok}

1. Gyüjtsön további könyvtárdefiníciókat!

2. Vesse össze az 1997. évi CXL. törvény kihirdetéskori szövegét a hatályban lévő, a módosításokat is tartalmazó változatával! Melyek a legfontosabb változások?

3. A Könyvtári Intézet honlapján elérhető Magyarországi Könyvtárak Adatbázisában felsorolt valamennyi könyvtártípusra keressen egy-egy konkrét példát!

4. Olvasson el egy választott könyvtártípushoz tartozó IFLA útmutatót és hasonlítsa össze a vonatkozó magyar jogszabályokkal!

5. Gyüjtse össze azokat az ismérveket, amelyek minden könyvtártípusra jellemzőek!

6. Keressen az interneten néhány könyvtári küldetésnyilatkozatot! Milyen alapvető célokat fogalmaznak meg?

7. A Könyvtárak Minőségi Működésének Értékelési Rendszerének egy választott kritériuma alapján gondolja végig, melyek a legfontosabb szempontok, amiket figyelembe kell venni egy új könyvtár tervezésekor!

8. Îrjon példákat korlátozottan nyilvános könyvtárra!

\section{Ajánlott irodalom}

BARÁTNÉ HAJDU Ágnes: Bevezetés a könyvtárhasználati ismeretek oktatásába. Budapest, Eötvös Loránd Tudományegyetem, 2015. 89 p. Forrás: http://metodika.btk.elte.hu/file/TAMOP_BTK_BMK_8.pdf

BÉNYEI Miklós: Lokalitás - többféle látószögből. = Könyvtári Figyelő, 64 . évf. 1. sz. 2018. 74-82. p. Forrás: http://epa.oszk.hu/01300/01367/ 00294/pdf/EPA01367_3K_2017_09_016-020.pdf

CSÍK Tibor (szerk.): Könyvtár és iskola: tanulmányok. Budapest, ELTE BTK Könyvtár- és Információtudományi Intézet, 2020. 222 p. Forrás: https://doi.org/10.21862/978-963-489-189-5 
DUDÁS Anikó: Információs műveltség felsőfokon: Szakirodalmi forráskutatás a bölcsészet- és társadalomtudományokban. Budapest-Piliscsaba, PPKE BTK, 2016. 217 p. Forrás: https://btk.ppke.hu/uploads/ articles/4090/file/Dud\%C3\%A1s_IMF_2016.pdf

GÁBORJÁNI SZABÓ Botond: A magyarországi egyházi könyvtárak helyzete, céljai és jövőképe. = Könyvtári Figyelő, 48. évf. 1-2. sz. 2002.1127. p. Forrás: http://epa.oszk.hu/00100/00143/00041/pdf/EPA00143_ konyvtari_figyelo_2002_1_2_011-027.pdf

GÁBORJÁNI SZABÓ Botond: Az egyházi könyvtárak változásai, sikerei és kudarcai az elmúlt másfél évtizedben. = Könyvtári levelező/lap, 15. évf. 12. sz. 2003.11-13. p. Forrás: http://epa.oszk.hu/00300/00365/00025/ pdf/KLL_EPA00365_2003-12_011-013.pdf

KÁLDOS János: A (nemzeti) könyvtár állandósága és változása. In: Kiszl Péter - Csík Tibor (szerk.): Valóságos könyvtár - könyvtári valóság. Könyvtár- és információtudományi tanulmányok 2018. Budapest, ELTE BTK Könyvtár- és Információtudományi Intézet, 2018. 31-42. p. Forrás: https://doi.org/10.21862/vkkv2018.31

KISZL Péter: Alapítvány a könyvtárért: közgyűjteményi forrásteremtés civil eszközökkel. = Tudományos és Müszaki Tájékoztatás, 62. évf. 6. sz. 2015. 223-245. p. Forrás: http://tmt.omikk.bme.hu/tmt/article/view/ 210/211

KISZL Péter: Az IFLA stratégiai célkitűzései - hazai és nemzetközi könyvtári párhuzamok. In: Szabó Panna - Székelyné Török Tünde (szerk.): Hagyományok és kihívások V. Múlt és jövő : Országos Könyvtárszakmai Nap, 2016. Budapest, ELTE Egyetemi Könyvtár és Levéltár, 2017. 19-36. p. Forrás: http://doi.org/10.21862/HagyKihiv_2016.19

KISZL Péter: Könyvtárak a közösségért - New Yorkban. = Tudományos és Műszaki Tájékoztatás, 61. évf. 9. sz. 2014. 315-330. p. Forrás: http:// tmt.omikk.bme.hu/tmt/article/view/433/10493

KISZL Péter: Multidiszciplináris könyvtárosképzés és multifunkciós egyetemi könyvtár a tudásalapú gazdaság kontextusában. In: Szabó Panna - Székelyné Török Tünde (szerk.): Hagyományok és kihívások VIII. Országos Könyvtárszakmai Nap, 2019. Budapest, ELTE Egyetemi Könyvtár és Levéltár, 2020. 29-62. p. Forrás: https://doi. org/10.21862/HagyKihiv_2019.29 
KISZL Péter - NÉMETH Katalin (szerk.): Információközvetítés és közösségépítés - multifunkciós könyvtári hálózatok. Budapest, ELTE BTK Könyvtár- és Információtudományi Intézet, 2020. 342 p. Forrás: https://doi.org/10.21862/infkoz

KOKAS Károly: Kalauz a modern könyvtárak világába: a könyvtárak új feladatai és megváltozott szerepük a 21. század elején. Budapest, Akadémiai Kiadó, 2020. Forrás: https://doi.org/10.1556/9789634545736

KOONTZ, Christie - GUBBIN, Barbara (ed.): IFLA Public Library Service Guidelines. Berlin/Munich, De Gruyter Saur, 2010. 149 p. Forrás: https://doi.org/10.1515/9783110232271

LENCSÉS Ákos - SÜTŐ Péter: Online tartalmak konzorciumi beszerzése. = Könyv, Könyvtár, Könyvtáros, 27. évf. 11. sz. 2018. 28-33. p. Forrás: http://epa.oszk.hu/01300/01367/00308/pdf/EPA01367_3K_2018_ 11_028-033.pdf

MOLDOVÁN István: A digitálisan született tartalmak megőrzése. = Könyv, Könyvtár, Könyvtáros, 27. évf. 10. sz. 2018. 18-26. p. Forrás: http://epa. oszk.hu/01300/01367/00307/pdf/EPA01367_3K_2018_10_018-026.pdf

NAGY Zsuzsanna - KARÁCSONY Gyöngyi: A kutatás és az oktatás innovációs csomópontjai: a felsőoktatási könyvtárak stratégiai fejlesztési irányai 2018-2023. = Tudományos és Műszaki Tájékoztatás, 66. évf. 7-8. sz. 2019. 420-429. p. Forrás: https://tmt.omikk.bme.hu/tmt/ article/view/12334/14027

NÉMETH Katalin: A turkológia szolgálatában: a Hazai György Könyvtár. = Tudományos és Műszaki Tájékoztatás, 66. évf. 6. sz. 2018. 348-362. p. Forrás: https://tmt.omikk.bme.hu/tmt/article/view/12311/14002

SÖRÉNY Edina: A könyvtári rendszer támogatásai az elmúlt 10 év tükrében. = Tudományos és Műszaki Tájékoztatás, 67. évf. 1. sz. 2020. 12-32. p. http://tmt.omikk.bme.hu/tmt/article/view/12479/14224 
DOKUMENTUMTIPOLÓGIA

\section{DOKUMENTUMTIPOLÓGIA}

A dokumentum fogalma, ahogy a könyvtárak gyüjtőköre, számos változáson ment keresztül, és jelentéstartalma is folyamatosan bővült. A könyvtáralapítás első lépései között, amint az előző fejezetben már utaltunk rá, a gyűjtőköri szabályzatban meg kell határozni azoknak a dokumentumoknak a típusait, jellemzőit, amelyet az intézmény gyűjteni, illetve szolgáltatni szeretne.

A XX. században Paul Otlet és a dokumentalisták nyomán az 1937-es definíció szerint bármilyen, anyagilag testet öltött - tájékoztatásra, tanulmányi céllal vagy forrásmüként használatos - információ lehet dokumentum. Suzanne Briet (1894-1989) az állatkerti élőlényeket is a dokumentumok közé sorolta, szemben a természetes élőhelyükön élő társaikkal. Miért ne vonhatnánk párhuzamot egy kiállítási tárgy vagy egy könyvtári dokumentum között? A közös, hogy mindhárom esetben az érdeklődők számára információval kell szolgálnunk az említett entitásokról. Tószegi Zsuzsanna értelmezése alapján „a dokumentumot úgy definiálhatjuk, mint egy önálló szellemi terméket, egy független információegységet, az információk különálló kvantumját, melynek célja az információ közlése, a tudás átadása." ${ }^{25}$

Az egyes dokumentumtípusok meghatározása, a közöttük lévő különbségek összevetése azért szükséges, mert a szolgáltatások szervezése mellett hatással van a könyvtári terek, raktárak kialakítására. A különböző dokumentumtípusok eltérő állományvédelmi eljárásokat igényelnek, így a könyvtári épület tervezésekor figyelembe kell venni legalább néhány alapvető biztonsági és állományvédelmi szempontot. Nagyon fontos (lenne), hogy a tervezők és a fenntartók megértsék: sem a padlás/tetőtér, sem az alagsor/pince nem alkalmas könyvek elhelyezésére, raktározására. Az épület fizikai védelme, a vagyonbiztonság megteremtése összefügg a könyvtár elhelyezkedésével, a felhasznált anyagokkal, a terek kialakításával. A megfelelő szilárdságú és jól szigetelő falak, valamint nyílászárók védelmet biztosítanak

${ }^{25}$ TÓSZEGI Zsuzsanna: Dokumentumok, információhordozók. In: Horváth Tibor - Papp István (szerk.): Könyvtárosok kézikönyve. 1. Alapvetés. Budapest, Osiris Kiadó, 1999. 168. p. Forrás: https://mek.oszk.hu/18000/18066/18066.pdf 
a behatolók ellen, illetve néhány elemi kár elhárítását is lehetővé teszik. A rádiófrekvenciás azonositási módszer (Radio Frequency IDentification RFID) szintén a vagyonvédelmet segíti, mivel a beléptető kapuk és a dokumentumokon elhelyezett RFID-címkék megnehezítik a dokumentumok engedély nélküli kivitelét az intézményből.

Fontos szempont a személyzet állományvédelemmel kapcsolatos képzése, valamint a felelősségteljes munkavégzés, például a veszélyeztetett pontok gyakori ellenőrzése. Hiába van kiváló minőségű ablakunk, akár még UV-szürő fóliával is ellátva, ha az a nap végén nyitva marad. Amenynyiben a könyvespolcok vége nyitott, azaz nem rendelkezik semmilyen támasztékkal, minél nagyobb számú könyvtámasz beszerzése szükséges, még mielőtt a polcra kerülnének a kötetek. Ezek a szempontok evidenciának tűnhetnek, de a hosszú távú megőrzés érdekében megkerülhetetlenek.

\section{Dokumentumtípusok, információhordozók}

A dokumentumokkal kapcsolatban számos csoportosítási lehetőség adódik, az alábbiakban az információhordozó alapján vázoljuk ezeket.

A könyvtárosok jól tudják, hogy a dokumentumismeret alapvető jelentőségű a feldolgozó munkában. A dokumentumok formai és tartalmi jellemzőinek pontos meghatározása a szolgáltatások alapját képező katalógusok, adatbázisok minőségének záloga. Amíg ez a fejezet inkább a formai jegyeket, addig a következő rész a tartalmi ismérveket tárgyalja. A könyvtáros képzettségủ olvasók számára a legtöbb itt felsorakoztatott szempont jól ismert, de útmutatónkból mindezek nem hiányozhatnak.

A hagyományos szöveges dokumentumok legáltalánosabb csoportjától elindulva már számos kérdés felmerül. A könyvek például tovább bonthatók az elóállítás technikájára tekintettel kéziratos, nyomtatott, elektronikus és egyéb technológiával előállított művekre. A fizikailag létező, kézzel fogható gyüjtemény szempontjából - adott esetben - fontos lehet a méret (nagyméretü, miniatür vagy mikroszkopikus), a fizikai forma (leporelló, különleges formájú kötetek) és más egyéb szempontok. A katalógustételben megjelenik a kötésre vonatkozó információ (kötött, füzött, szabadlapos), közölni kell, ha a könyv illusztrált, vagy ha nem az első kiadásról van szó (bibliofil, 
a másodiktól kezdve a kiadásjelzés, javított és/vagy bővített kiadás, utánnyomás, hasonmás stb.), és le kell írni a könyv egyéb fontos jellemzőit.

A kéziratos könyvek között találjuk egyrészt a kódexeket, amelyeket a középkori, kora újkori egyéb kéziratokkal együtt a 22/2005. sz. NKÖM rendelet értelmében muzeális dokumentumnak kell tekinteni. A rendeletben meghatározott dokumentumokról a könyvtár nyilvántartást vezet, a felhasználók számára azokat az állományvédelmi szempontok maximális betartása mellett prézens módon szolgáltatja, valamint tájékoztatja az Országos Széchényi Könyvtárat a gyűjteményébe tartozó valamennyi muzeális dokumentumról és az intézmény adatairól, illetve az adatokban történő esetleges változásokról. ${ }^{26}$

A kéziratok közé tartoznak az oklevelek, amelyek a levéltárak ${ }^{27}$ gyüjtökörébe sorolhatók. Több felsőoktatási könyvtár is van, amely egy szervezeti egységet alkot az adott intézmény levéltárával, ahol - többek között - az oktatással kapcsolatos dokumentumot gyüjtik. Itt kell megemlíteni például az írói magánlevelezéseket, az eredeti szerzői kéziratokat, amelyeket a könyvtárak általában a többszörözött könyvektől és egyéb dokumentumoktól elkülönítve, különgyüjteményben kezelnek. Ezek a példák jól mutatják, hogy egyes dokumentumtípusok felvethetnek akár terminológiai kérdéseket, akár a különböző közgyüjteménytípusok közötti gyüjtőköri átfedéseket.

A mai értelemben vett könyv jellemzői a XVI. században váltak általánossá: „kötelező” elem lett a címlap a címre, szerzőre, valamint a kiadóra vonatkozó adatokkal, a borítófedél, valamint az egybefüzött lapokból álló könyvtest. A hagyományos, nyomtatott könyvek legalább kettő, jól elkülöníthető részből állnak: egyrészt maga a kötéstábla vagy borítófedél (védőborító fülszöveggel, könyvtok), másrészt a beleerősített könyvtest, de tartozhatnak hozzá a könyvtesttől független részek, mellékletek (például CD,

${ }^{26} 22 / 2005$. (VII. 18.) NKÖM rendelet a muzeális könyvtári dokumentumok kezelésével és nyilvántartásával kapcsolatos szabályokról. Forrás: https://net.jogtar.hu/jogszabaly?docid=a0500022.nkm

A rendelet szövegében részletesen olvasható a muzeális könyvtári dokumentumok közé tartozó valamennyi további dokumentumtípus. A jogszabály a nyilvános könyvtárak mellett a nem nyilvános könyvtárakra is vonatkozik.

A Muzeális Könyvtári Dokumentumok Nyilvántartásához ld.: MKDNY: Forrás: https:// mkdny.oszk.hu

${ }^{27}$ Ld.: 1995. évi LXVI. törvény a köziratokról, a közlevéltárakról és a magánlevéltári anyag védelméről. Forrás: https://net.jogtar.hu/jogszabaly?docid=99500066.tv 
térkép). Más felosztás szerint a könyv részei a föszöveg, a járulékos részek (szennycímlap, függelék stb.) és a könyvborító.

Az OSZK tezaurusz/köztauruszban a könyv szóra keresve több definíciót találunk - köztük az érvényes szabványok meghatározását -, amelyek között a minimális terjedelem és a már említett felépítés mutat hasonlóságot. A tezaurusz az egyes meghatározások mögött azok forrását is közli:

- „Nem időszaki kiadvány, amelynek terjedelme - a fedőlapokat nem számítva - legalább 49 oldal (3, egyenként 16 oldalas nyomdai ív), nem zenemű, jegyzék, program, naptár, szabályzat, menetrend stb. [UNESCO]"

- „a fedőlapokat nem számítva legalább 49 oldal terjedelmü kiadvány [MSZ EN ISO 9707];"

- „Nyomdatermék, amely két fedőlapból, valamint meghatározott sorrendben egymást követő - esetenként kivehető - a gerincen tartósan összeerősített belső lapból áll, és olvasható szöveget, ill. illusztrációt tartalmaz [MSZ 5602]."

- „3 ívnél (1 ív = 40 ezer betűhely) nagyobb terjedelmű nyomtatott írásmü, amely két fedőlapból, valamint meghatározott sorrendben egymást követő - esetenként kivehető -, a gerincen tartósan összeerősített belső lapokból áll, és olvasható szöveget, ill. illusztrációt tartalmaz [NAVA]."28

Magyarországon 1974-től alkalmazzák a könyvek nemzetközi azonosító számát, az International Standard Book Numbert (ISBN). Az OSZK-ban működő ISBN Iroda térítésmentesen biztosítja a magyarországi székhelyü kiadók számára az ISBN-t, amely 2007-től 13 számjegyből áll. ${ }^{29}$ Az ISBN-t nemcsak a papíralapú könyvek és könyvjellegű dokumentumok kaphatják meg, és a fenti szabvány előírta 49 oldalas minimális terjedelemmel ellentétben már 16 oldal is elegendő az igényléshez. Itt érdemes idézni, pontosan milyen dokumentum kaphat ISBN-t, mivel jól szemlélteti a könyv értelmezésének átalakulását:

- „Nyomtatott könyvek, brosúrák (min. 16 oldal);

\footnotetext{
${ }^{28}$ Valamennyi meghatározás forrása az OSZK Tezaurusz/Köztaurusz. Forrás: https:// mek.oszk.hu/cgi-bin/thes.cgi?desc $=\mathrm{k} \% \mathrm{~F} 6$ nyv\&trunc $=1$

${ }^{29}$ Magyar ISBN és ISMN Iroda. Forrás: http://www.oszk.hu/isbn_ismn_iroda Magyarország azonosítója a 963, illetve 2010-től a 615 is.
} 
- Braille kiadványok;

- Térképek;

- Oktatási célú videó- és diafilmek, szoftverek;

- Kazettán, CD-n vagy DVD-n kiadott hangoskönyvek;

- Elektronikus kiadványok, akár fizikai hordozón, akár online hozzáféréssel;

- Multimédiás kiadványok, amennyiben a tartalom túlnyomó része szövegalapú."30

Az ISBN és a könyvek átvezetnek bennünket az ún. folytatódó kiadványokhoz, amelyek közé az idöszaki kiadványok, sorozatok tartoznak. A folytatódó kiadvány olyan, előre meg nem határozott időtartamra tervezett dokumentum, amely „egymást követő részegységekben jelenik meg, és általában számozással vagy kronologikus megjelöléssel van ellátva." ${ }^{31}$ Az International Standard Serial Number (ISSN), az időszaki kiadványok nemzetközi szabványos számozása azonosítja ezeket a dokumentumokat. A sorozatok tagjai egyszerre kapják meg a teljes sorozatot azonosító ISSN-t, és az egyes kötetek azonosítására alkalmas ISBN-t. A rendszeresen megjelenő periodikumok (évkönyvek, folyóiratok, napilapok stb.) kizárólag ISSN-t kapnak.

A hagyományos, nyomtatott periodikumok egyik jellemzője a sajátos méretezés, gyakran meglehetősen vékony lapokkal, amely a hosszú távú megőrzés érdekében fokozott állományvédelmi előkészületeket igényel. Míg a legtöbb könyvet a keménytáblák hosszabb távon is stabilan tartják, a folyóiratokat a könyvtárak kénytelenek évfolyamonként egybeköttetni vagy a levéltári gyakorlat mintájára savmentes dobozokban elhelyezni. Itt érdemes megjegyezni, hogy a gyüjtőkör meghatározásakor ki kell térni az egyes dokumentumtípusok tervezett megőrzési idejére, mivel ez nyilvánvaló hatást gyakorol az adott információhordozó tárolási módjára.

A szöveges dokumentumok, amelyek egyúttal vizuális dokumentumok, leggyakrabban írásjelekkel rögzített vagy egyéb egyezményes jelrendszert használó alkotások. Utóbbira lehetnek példák a kották. A kereske-

\footnotetext{
${ }^{30}$ ISBN útmutató. Összeáll. Csirmazné Rezi Éva és Szabó Erika Zita. 5. átd. kiad. Budapest, OSZK, 2012. 8. p. Forrás: http://ki.oszk.hu/content/szabvanyokszabalyzatok-utmutatok-iranyelvek

${ }^{31}$ I.m. 26. p.
} 
delmi forgalomba, vagy ingyenes terjesztésre kerülő, vagy bérbe vehető, vagy csak szerzői jogi célokra hozzáférhető kották, partitúrák azonosítására szolgál az International Standard Music Number (ISMN). ${ }^{32}$

Ugyancsak a vizuális dokumentumok közé sorolhatók az ikonográfiai alkotások, amelyek közös jellemzője a képi ábrázolás. Ezek lehetnek egy könyv részei, de önálló dokumentumtípust is képviselhetnek, hiszen a fotók, térképek szolgálhatnak egyrészt illusztrációként, de önmagukban különgyüjteményt is képezhetnek.

A könyvtárak számára komoly kérdést jelent a kis- és aprónyomtatványok válogatása, megőrzése és feldolgozása. A kisnyomtatvány terjedelme nem éri el az egy nyomdaívet, míg az egy, legfeljebb két lapnyi dokumentumot nevezzük aprónyomtatványnak. Ez utóbbiak lehetnek szöveges vagy képi dokumentumok, ide tartoznak például az ex librisek, szentképek, báli meghívók, gyászjelentések. ${ }^{33}$

Az információ-érzékelés történhet tapintás útján, mint a Braille-írásos dokumentumok esetében, amelyek a látássérült olvasók számára teszik elérhetővé a rögzített tartalmat. Az írott szövegek nem csak a Braille-írás segítségével, hanem egyéb módon is hozzáférhetővé válhatnak a látássérültek számára, úgy mint auditív dokumentumokkal, például hangoskönyvekkel, de a felolvasó szoftverekkel a képernyőn megjelenő szöveg is hallhatóvá alakítható. Tapinthatóak a térbeli kiterjedéssel rendelkező, ún. plasztikai alkotások is (pl. érmék), azonban ez a csoport jellemzően már a múzeumok gyüjtőkörébe tartozik, bár néhány nagyobb múltra visszatekintő könyvtár is öriz például érmegyűjteményt.

A hagyományos, nyomtatott dokumentumokra általában jellemző, hogy szabad szemmel, segédeszköz nélkül olvashatók, azonban az auditív, valamint az audiovizuális dokumentumok tartalmához már csak közvetett módon, valamilyen lejátszó eszköz segítségével lehet hozzáférni. A könyvtári gyüjtemény tervezésekor épp ezért azt is szükséges végiggondolni, milyen speciális eszközöket fog igényelni a választott dokumentumtípus, valamint ezen eszközök használói számára tudunk-e megfelelő teret kialakítani. Nem lehet elégszer hangsúlyozni, hogy a könyvtár típusa

${ }^{32}$ ISMN útmutató. 2. kiad. Összeáll. Szabó Orsolya és Tóth Eszter. Budapest, OSZK Magyar ISBN és ISMN Iroda, 2008. 9.p. Forrás: http://www.oszk.hu/sites/default/files/ ISMN_utmutato.pdf

${ }^{33}$ OSZK Plakát- és Kisnyomtatványtár. Forrás: http://www.oszk.hu/plakatok_kisnyomtatvanyok 
és a megcélzott használói csoport együttesen gyakorol hatást a gyüjtőkörre és az állományalakításra.

Már említettük a vizuális, illetve az auditív dokumentumokat, mint a szöveg közlésének lehetséges módját, azonban eredetileg a kép-, hang- és egyéb dokumentumok csoportja jóval többféle információhordozót jelent. A hangdokumentumok rendszerint a könyvtárak zenei részlegein találhatók, és az elmúlt évtizedek során szintén számos változáson mentek keresztül, ami ugyancsak folyamatos kihívás elé állítja a szolgáltató intézményeket. A fizikai hordozókon kiadott audiokazettáktól a hanglemezeken, majd CDlemezeken át jutottunk el a különböző online formátumokig, mint például az MP3-ig, hogy végül, teljesen megváltoztatva a zenehallgatási szokásokat, megtapasztalhassuk a legális streamelés (streaming) jelenségét.

Az interneten elérhető hangfelvételek rögzítésének előfeltétele a szerzői jogi engedélyek megléte. A kulturális törvény 2021. január 1-jétől a nemzeti könyvtár feladatkörébe beemelte a webaratást, így az OSZK a törvény erejénél fogva tölti le a hungarikumok közé tartozó hangfelvételeket is azokról a honlapokról, amelyek jogtulajdonosaival a webaratásra vonatkozó írásbeli szerződést kötött. ${ }^{34}$

$\mathrm{Az}$ analóg hangdokumentumok közé tartoznak a barázdás, egy-, majd kétoldalas, vékony hanglemezek, amit a magyar köznyelvben „bakelitlemeznek" is neveznek, bár a bakelithez semmi közük nincsen. Az audio- vagy magnókazetta az 1970-es, 1980-as években volt különösen népszerü. A könyvtárakba leggyakrabban az idegen nyelvek tanulását elösegítő tankönyvek mellékleteiként kerültek a magnókazetták; jelentőségük mára erősen visszaszorult.

A digitális hangdokumentumok között 1982-ben jelent meg elsőként a CD-lemez (az angol Compact Disc rövidítése) a Philips langenhageni gyárában. ${ }^{35} \mathrm{~A}$ korong átmérője $(12 \mathrm{~cm})$ változatlan maradt, de hamarosan a hang mellett képek és egyéb adatok tárolására is alkalmassá vált $(C D$ $R O M$ ), azonban a rögzített tartalomtól függően, különböző lejátszó eszközök szükségesek az adatokhoz való hozzáféréshez. A hangfelvételeket tartalmazó CD-lemezek az erre szolgáló lejátszó eszközökkel hallgathatók meg

\footnotetext{
${ }^{34}$ 1997. évi CXL. törvény a muzeális intézményekről, a nyilvános könyvtári ellátásról és a közmüvelődésről. Forrás: https://net.jogtar.hu/jogszabaly?docid=99700140.TV

3525 éves a CD-lemez. $=$ Hetek, 11. évf. 34. sz. 2007. szept. 14. Forrás: https://epa.oszk. hu/00800/00804/00496/65699.html
} 
- a könyvtárak állományába tipikusan zenei felvételek vagy hangoskönyvek kerülnek ezen a hordozón. Amilyen nagy ígéretként indultak a gyakran multimédia elemeket tartalmazó CD-ROM-ok, olyan gyorsan váltak szinte használhatatlanná ezek az információhordozók. A lejátszásukhoz ugyanis számítógép kell, és az eszközök gyors fejlődése miatt napjainkban a 20-30 éves számítógépek már nem müködőképesek, a régi, mára elavult szoftverekre fejlesztett CD-ROM-ok pedig lejátszhatatlanok.

A multimédia - vagyis a szöveg mellett álló- vagy mozgóképet és hangot, illetve videót tartalmazó összeállítások fejlődése szorosan összefügg a CD-ROM-ok, DVD-k és az internet világával. Napjainkban lassan a multimédia fogalma is kiveszőfélben van, a helyét gyakorlatilag átvette az online videó. A könyvtárak számára nehéz kérdés, mi legyen a sorsuk a korábban állományba vett, gyakran értékes tartalmat hordozó optikai lemezeknek.

Az audiokazettához hasonlóan a mágnesszalagos adattárolók közé tartozik a videokazetta, melynek lejátszásához nem volt elég egyetlen eszköz, a videomagnó mellett televízióra is szükség volt. Az ezredforduló után kezdtek elterjedni a $D V D$ (Digital Versatile Disc vagy Digital Video Disc), valamint a Blu-ray lemezek, amelyek nagyobb mennyiségü adat jó minőségü tárolására is képesek. A videofilmek tekintetében is megfigyelhető a további digitális formátumok (például $A V I, M P 4$ stb.) megjelenése és az online hozzáférés. A könyvtári gyakorlatban általában a fizikailag megfogható információhordozón megjelent dokumentumok kerülnek az állományba. Az online elérhető tartalmak könyvtári kezelése a letöltéssel és a tartós tárolással összefügg. Nem győzzük hangsúlyozni, hogy az internetes tartalmakat csak a szerzői jogi törvény adta legális keretek között szabad letölteni.

Ha definiálni szeretnénk, akkor az egyik legnehezebben körülírható dokumentumtípus az elektronikus könyv, vagyis az e-könyv, mivel a köznyelvben gyakran keveredik a formátum és az olvasásához szükséges eszköz, az e-könyv olvasó. Kérdés, hogy milyen formátumban érdemes az e-könyveket létrehozni. Korábban általános volt a webböngészők által használt $H T M L$, újabban a $P D F$ formátum a leggyakoribb A hazai e-könyvtárak között a legismertebb Magyar Elektronikus Könyvtár (MEK) ${ }^{36}$ a HTML és PDF mellett kínál e-könyv formátumban (EPUB vagy PRC) is dokumentumokat. A könyvtári állományba a MEK-ről és a többi digitális könyvtárból csak azokat az e-könyveket szabad letölteni, amelyek vagy

\footnotetext{
${ }^{36}$ Magyar Elektronikus Könyvtár. Forrás: https://mek.oszk.hu
} 
a közkincs (public domain) körébe tartoznak, vagy amelyek felhasználására a jogtulajdonos engedélyt ad. A Digitális Irodalmi Akadémia (DIA) teljes állománya szerzői jogi védelem alatt áll, így abból az adatbázisból sem magánszemély, sem könyvtár nem töltheti le a műveket.

\section{Dokumentumtípusok, információtartalom}

Az előzőekben röviden áttekintettük a különböző információhordozók sajátosságait, de nem szóltunk az azokban fellelhető tartalmakról. Ha csak a könyvek sokféleségére gondolunk, a legáltalánosabb felosztás alapján beszélhetünk szép- és szakirodalomról, melynek a gyüjteményben elfoglalt arányát a könyvtár típusa szinte önmagában képes meghatározni: egy települési könyvtárban a szépirodalom nagyobb hányadot foglal el, míg egy szakkönyvtárból valószínűleg ez a „müfaj” teljesen hiányzik.

A tárgyalásmódot befolyásolja a megcélzott olvasóközönség, így például más a stílusa a gyermek- és ifjúsági irodalomnak vagy az oktatási anyagoknak, tankönyveknek, az ismeretterjesztö, illetve a szakirodalomnak. A kifejezésmód így például lehet szépirodalmi, életrajzi, hivatalos, tudományos stb. A Magyar Tudományos Müvek Tára (MTMT) a publikációkat a következő kategóriákba sorolja: tudományos, oktatási, közérdekü, ismeretterjesztő. ${ }^{37}$

A szépirodalom és a szórakoztató irodalom (angol terminológiával fiction) tovább bontható münemek (líra-dráma-epika), azon belül akár müfajok (pl. regény, novella, esszé) alapján. A szépirodalom jellemzően a közkönyvtárak és az iskolai könyvtárak gyüjtőkörébe tartozik, de kötelespéldányként a nemzeti könyvtár, kötelező irodalomként a felsőoktatási könyvtárakban is megjelenhet. A gyermek- és ifjúsági irodalom elsősorban a 18 év alatti olvasóknak szól, azonban egyre népszerủbbek a felnőttek körében is az ún. young adult kötetek. A kisgyermekek számára írt könyvek számos képet tartalmaznak, azonban körültekintően kell eljárni a szintén nagy keresettségnek örvendö képregényekkel, illetve az akár kifejezetten felnőtteknek szóló mangákkal, hogy a megfelelő helyre kerüljenek a könyv-

\footnotetext{
${ }^{37}$ Magyar Tudományos Művek Tára. Forrás: https://www.mtmt.hu/dokumentumok
} 
tári polcokon. A szépirodalom körébe tartozó kötetek megjelenhetnek az előző fejezetben említett papíralapú, hangoskönyv vagy e-könyv formában.

Minden könyvtártípusban jelen vannak a szakirodalom körébe tartozó művek, melyek legismertebb típusai az alábbiak:

- monográfia: egyetlen témát feldolgozó könyv, gyakran tudományos igényű munka;

- tanulmánykötet: egy vagy több szerző által írt, rendszerint rövidebb, önálló műveket tartalmaz;

- szótár: a szócikkek betürendben következnek egymás után, gyakori a kéthasábos elrendezés:

○ az egynyelvű értelmező szótárak a jelentést magyarázzák (pl. történeti szempontból az etimológiai szótárak);

○ a többnyelvủ szótárak két vagy több nyelven feleltetik meg egymásnak a szavakat, kifejezéseket az idegennyelvü megfelelőjük megadásával;

- lexikon: a betürendbe sorolt szócikkek tömören ismertetik a lexikon tárgyához tartozó fogalmakat (pl. művészeti lexikon);

- enciklopédia: egy tudományág vagy nagyobb szakterület tudásanyagának teljeskörű bemutatását célozza meg; fö jellemzője a tematikus vagy kronologikus elrendezés; az egyes témák általában feltüntetik a szerző nevét; mutatók és irodalomjegyzék egészíti ki;

- bibliográfia: adott időszakban és/vagy szakterületen megjelent müvek jegyzéke.

Eddig még nem említettük a publicitás kérdéskörét, pedig az utóbbi időkben ez szintén alapvető változáson ment keresztül. A papíralapú kiadványok idején publikáltnak tekintettünk egy dokumentumot, amennyiben legalább 50 példányban megjelent, és ezzel elérte a kötelespéldányrendelet alsó határát. Amióta a világhálón is közzé lehet tenni szerzői műveket, azok a dokumentumok is publikáltnak számítanak, amelyek a korlátozás nélküli, nyílt internetes felületen (a surface weben) elérhetők - mint például a kötelezően közzéteendő doktori disszertációk. A csak előfizetéssel elérhető elektronikus dokumentumok hozzáférése korlátozott, de ezek túlnyomó többsége - például sok tudományos folyóirat - papírhordozón is megjelenik. A nyomdatermékek világában a könyvtárak számon tartották az ún. szürke irodalom zónáját, amelybe az alacsony példányszámú, kereskedelmi 
forgalomba általában nem kerülő, de gyakran magas információértékű dokumentumok tartoztak (pl. kutatási jelentések).

Főként a kereskedelmi forgalomba kerülő szakirodalom árának hatalmas emelkedése miatt egyre erőteljesebb a törekvés és igény - elsősorban a kutatók részéről -, hogy legalább a közfinanszírozott tudományos kutatási eredmények minél inkább átláthatók és elérhetők legyenek: e célra sorra alakulnak az open science kiadók és repozitóriumok.

A felsorolt dokumentumtípusok közül valamennyire találunk példát a nyomtatott és az online elérhető dokumentumok között. Az ezredforduló után számos esetben már kizárólag digitális formában jelennek meg bizonyos szakirodalmi források. A tájékozódást, de a gyüjteményszervezést is nehezíti, azonban a megnövekedett információ- és dokumentummennyiség miatt egyre fontosabbá válik, hogy különbséget tudjunk tenni a megbízható, releváns források és a folyamatosan szaporodó ún. parazita vagy más néven predátor ${ }^{38}$ folyóiratok között. Az elmúlt évtizedekben a tudománymetriai és bibliometriai kutatások, a hivatkozási indexek, a tudományos rangsorok igyekeznek támogatást nyújtani a kutatók és a könyvtárosok számára, hogy valóban az adott szakterület tudományos igényü, elismert dokumentumait válasszák, használják.

A szakkönyvek, azon belül a tudományos monográfiák fontos csoportját alkotják a doktori disszertációk, mivel velük szemben elvárás az új tudományos eredmények elérése és megfogalmazása, így mind a felsőoktatási, mind a szakkönyvtárakban helyük van. Fontos adalék, hogy a sikeres védés után a disszertációkat és a magyar és angol nyelvü téziseket kötelező nyilvánosságra hozni - ezt a felsőoktatási törvény írja elő. ${ }^{39}$ A szakdolgozatra nézve nincs ilyen kötelezettség, szerzőjük szabadon dönthet arról, publikálja-e a dolgozatát a világhálón, vagy sem; a diplomát adó felsőoktatási intézmény könyvtárában viszont a hallgató köteles egy példányt nyomtatásban és elektronikus hordozón elhelyezni.

Külön csoportot alkotnak a tankönyvek, amelyeket tovább lehet bontani a közoktatáshoz kapcsolódó, illetve a felsőoktatást érintő tananyagokra. A közoktatási tankönyvek jellemzően az iskolai könyvtárak gyüjte-

\footnotetext{
${ }^{38}$ Parazita folyóiratok. Forrás: https://www.mtmt.hu/system/files/parazita_folyoiratok. pdf

${ }^{39}$ 2011. évi CCIV. törvény a felsőoktatásról. 54/A. \$ Forrás: https://net.jogtar.hu/jogszabaly? docid=a1100204.tv
} 
ményében találhatók meg, teljeskörủ gyüjtésükre az Országos Pedagógiai Könyvtár és Múzeum (OPKM) hivatott. Az egyetemi hallgatók számára tankönyvként gyakran az adott tudományterület szakkönyvei szolgálnak.

Az audiovizuális dokumentumokat az előző fejezetben részint külön tárgyaltuk, noha már ott rávilágítottunk néhány hasonlóságra, azonban tartalmuk tekintetében is számos kapcsolódási pont figyelhető meg közöttük. A szórakozás, a tanulás, a szakmai ismeretek bővítésének eszközei lehetnek ezek a dokumentumtípusok, de vannak olyanok, amelyek a látás- és hallássérültek számára is elérhetők. A feliratos filmek nem csak DVD-n, hanem az online platformokon is megjelennek, ahol már lehetőséget biztosítanak az ún. Closed Caption (CC), zárt feliratokra, így nem csak a párbeszédek, hanem egyéb hangok, hanghatások leírása is látható. A kiadók a nyelvtanuláshoz is számos audiovizuális tananyagot kínálnak, amelyek korábban mellékletként jelentek meg a tankönyvekben, azonban a modern nyelvkönyvek és szótárak a kiegészítő anyagaikat már belépési kód, és az elérést mutató link segítségével teszik online módon elérhetővé. Ez a változás a könyvtári dokumentumok és szolgáltatások körére is hatással van, mivel a könyvtár nyílt rendszerként reagál környezetére. A könyvtáraknak a platformot és a hozzáférést kell folyamatosan biztosítaniuk, miközben törekedniük kell arra is, hogy a jelenleg még csak a régebbi információhordozókon elérhető adatokat mielőbb feltárják és átmentsék újabb eszközökre, amelyeken biztosítani tudják a hosszú távú megőrzést. 


\section{Ellenőrző kérdések, feladatok}

1. A fejezetben felsorolt dokumentumtípusokra írjon egy-egy konkrét példát!

2. Melyek a könyv fö részei? Mi a különbség a kolofon és az impresszum között?

3. Az Országos Széchényi Könyvtár különgyüjteményei alapján csoportosítsa a nemzeti könyvtárban őrzött dokumentumokat! Milyen lehetséges átfedéseket tapasztal az egyes állományrészek között?

4. Válasszon egy dokumentumtípust, és gyűjtse össze, milyen állományvédelmi szempontoknak kell érvényesülni a tartós megőrzéshez!

5. Milyen formátumok elérését teszi lehetővé a Magyar Elektronikus Könyvtár?

6. Milyen dokumentumtípusokhoz biztosít hozzáférést az Europeana kulturális örökségi adatbázis?

7. Az ISBN mellett milyen további dokumentumazonosítók léteznek?

\section{[4] Ajánlott irodalom}

ÁSVÁNYI Ilona: Állományvédelem egyházi könyvtárakban. = Könyvtári Levelező/lap, 18. évf. 7. sz. 2006. 3-11. p. Forrás: http://epa.oszk. $\mathrm{hu} / 00300 / 00365 / 00056 / \mathrm{pdf} / \mathrm{KLL}$ EPA00365_2006-07_003-010.pdf

FARKAS Gábor Farkas: Régi könyvek irodája. Megőrzés, nyilvántartás, szolgáltatás. = Könyv, Könyvtár, Könyvtáros, 29. évf. 1. sz. 2020. 1519. p. Forrás: http://epa.oszk.hu/01300/01367/00324/pdf/EPA01367_ 3K_2020_01_015-019.pdf

HORVÁTH Adrienn: „Előjelekről csak utólag látni, hogy jeleztek.” Állományvédelmi interjú Baranya Péterrel, a Piarista Központi Könyvtár igazgatójával. = Könyv, Könyvtár, Könyvtáros, 28. évf. 5. sz. 2019. $25-$ 34. p. Forrás: http://epa.oszk.hu/01300/01367/00315/pdf/EPA01367_ 3K_2019_05_025-034.pdf

GYURGYÁK János: Szerzők és szerkesztők kézikönyve. Budapest, Osiris Kiadó, 2018. 547 p. 
KASTALY Beatrix: A könyvtári állomány megőrzése és védelme. In: Horváth Tibor - Papp István (szerk.): Könyvtárosok kézikönyve. 1. Alapvetés. Budapest, Osiris Kiadó, 2005. 197-262 p.

KEREKES Pál: Az elektronikus könyv [elektronikus dok.]: e-könyv, e-könyvolvasó, e-könyv-kereskedelem. Budapest, Kossuth Kiadó, 2010.

KEREKES Pál - KISZL Péter: E-book krónika: fejezetek az elektronikus könyv történetéből. = Korunk (Kolozsvár), 3. évf. 10. sz. 2014. 15-26. p. Forrás: https://drive.google.com/file/d/OB_NJh_UJWEUOVkF1WkU2YjRXbGs/view?pref $=2 \&$ pli $=1$

KEREKES Pál - KISZL Péter: Az elektronikus könyvről - oktatáson innen és túl. = Iskolakultúra, 25. évf. 3. sz. 2015. 56-71. p. Forrás: http:// dx.doi.org/10.17543/ISKKULT.2015.3.56

KEREKES Pál - KISZL Péter - TAKÁCS Dániel: E-könyvészet: a digitális könyvkultúra alapvonásai. Budapest, ELTE BTK Könyvtár- és Információtudományi Intézet, 2013. 310 p.

KÖRMENDY Lajos (szerk.): Levéltári kézikönyv. Budapest, Osiris Kiadó, 2009. $788 \mathrm{p}$.

NAGY Gergely: Az RFID könyvtári felhasználása. = Tudományos és Müszaki Tájékoztatás, 63. évf. 1. sz. 2016. 38-48. p. Forrás: http://epa. oszk.hu/03000/03071/00092/pdf/EPA03071_tmt_2016_01_38-48.pdf

PALKOVICS Brigitta Éva: Képtelen képregénytörténet. Képregények a könyvtárakban. = Magyar Könyvszemle, 134.évf. 4.sz.2018.444-456.p. Forrás: http://dx.doi.org/10.17167/mksz.2018.4.444-456

SCHUBERT András: Új utak és útvesztők a tudományos publikálásban és a tudománymetriában. = Könyv és Nevelés, 20. évf. 1. sz. 2018. 7-29. p. Forrás: http://epa.oszk.hu/03300/03300/00013/pdf/EPA03300_konyv_ es_neveles_2018_1_007-029.pdf

SIMON Zoltán: Állománygondozás, raktározás, állományvédelem. Budapest, Könyvtári Intézet, 2001. 42 p.

TÓSZEGI Zsuzsanna: Dokumentumok, információhordozók. In: Horváth Tibor - Papp István (szerk.): Könyvtárosok kézikönyve. 1. Alapvetés. Budapest, Osiris Kiadó, 1999. 152-199. p. Forrás: https://mek.oszk. $\mathrm{hu} / 18000 / 18066 / 18066 . p d f$ 


\section{KÖNYVTÁRI SZOLGÁLTATÁSOK}

Az előző fejezetekben a könyvtár- és dokumentumtípusok sokszínűségét tekintettük át dióhéjban, most pedig néhány dokumentum- és információközpontú szolgáltatás mellett az új kihívásokról is szólunk. A hagyományos könyvtári feladatokon túl egyre nagyobb igény mutatkozik a felhasználók részéről a kulturális programok, illetve a szociális funkció iránt. A célok és az elvárások között megjelenik a zöldkönyvtári szemlélet, a társadalmi felelősségvállalás, valamint a fenntarthatóság is. A könyvtári rendszer feladata, hogy az állampolgárok az ország minden pontján ugyanahhoz az információhoz hozzáférjenek, amelyhez pedig nélkülözhetetlen a feladatmegosztás és az együttmüködés. A fejezet a XXI. század hazai könyvtáraival szemben támasztott alapvető igényeket villantja fel. Célunk, hogy a könyvtáralapítás elött felhívjuk a figyelmet a gyüjteményszervezésen túlmutató, megfontolandó kérdésekre.

\section{A szolgáltató könyvtár}

A könyvtár hagyományos feladatai közé tartozik a lakosság dokumentumokkal való ellátása az Országos Dokumentumellátási Rendszeren (ODR) keresztül. Az ODR-t a kulturális törvény ${ }^{40}$ és a 73/2003. (V. 28.) Kormányrendelet ${ }^{41}$ alapján hozták létre. Az ODR szolgáltató könyvtárai valamennyi könyvtártípust reprezentálják, így megtaláljuk közöttük a nemzeti könyvtárat, az országos szakkönyvtárakat, az állami egyetemi könyvtárakat és a megyei könyvtárakat egyaránt. Központja a Debreceni Egyetem Egyetemi és Nemzeti Könyvtár (DEENK) a Kultv. 63. \$ (2) pontjának megfelelően. Az ODR müködése az ország egész területére

\footnotetext{
40 1997. évi CXL. törvény 59. $\$$

${ }^{41}$ 73/2003. (V. 28.) Korm. rendelet az Országos Dokumentumellátási Rendszerről. Forrás: https://net.jogtar.hu/jogszabaly?docid=A0300073.KOR
} 
minden településtípusra kiterjed, a könyvek mellett minden információhordozót szolgáltat. ${ }^{42}$

A Magyar Országos Közös Katalógussal (MOKKA) egyesített ODR katalógus lehetővé teszi, hogy mind az olvasók, mind a könyvtárosok rövid idő alatt megtudják, hogy az általuk keresett dokumentum elérhetö-e valamelyik magyarországi könyvtárban. A könyvtárközi kölcsönzés lehetősége nem csak az olvasók számára biztosítja a dokumentumokhoz való hozzáférést, hanem az egyes könyvtárak állománygyarapítási döntéseire is hatással van.

A dokumentumokhoz való hozzáférés egyik alapkérdése az adatokkal gazdagon ellátott, felhasználóbarát katalógus megléte. A magyarországi könyvtárakban alkalmazott számos integrált könyvtári rendszer részét képező, online elérhető katalógus segíti az olvasókat a tájékozódásban. A formai és tartalmi feltárás szabályainak betartása és a felmerülő technikai kérdésekre adott válaszok együttesen járulnak hozzá a könyvtár szolgáltatásainak és magának a könyvtárnak a megítéléséhez. Az integrált könyvtári rendszer kiválasztását azonban számos tényező befolyásolja, úgy mint a feldolgozni kívánt állomány mérete, a többnyelvűség kérdése, az együttmüködési lehetőségek stb. A szakkönyvtárak és a felsőoktatási könyvtárak honlapjaival és katalógusaival szemben is alapvető elvárás, hogy a magyar nyelv mellett legalább angol nyelven is elérhetőek legyenek, de a nemzetközi mobilitás megkönnyítése érdekében a két-, vagy többnyelvűség más könyvtártípusok esetében is fontos cél.

Nem szabad megfeledkezni azonban arról sem, hogy a feltárás elméletében, gyakorlatában és informatikai megvalósításában is paradigmaváltás zajlik, számos új szabvány, formátum kidolgozása van folyamatban.$^{43}$ Elsősorban a felsőoktatási könyvtárakban, de más könyvtártípusokban is egyre népszerübbé válnak az ún. discovery szolgáltatások, amelyeknek köszönhetően már nem csak a katalógusban kereshetünk, hanem egyetlen keresés

\footnotetext{
${ }^{42}$ Országos Dokumentumellátási Rendszer. Forrás: http://www.odrportal.hu/web/guest/ mi-az-odr. A különböző források eltérő módon írják le az ODR teljes nevét - kötetünkben a Kultv. névformáját használjuk.

${ }^{43}$ Például az OSZK-ban mủködik az RDA (Resource Description and Access) katalogizálási szabályzat magyarországi bevezetését előkészítő és koordináló munkacsoport. Feladata az új kommunikációs formátumok (MARC21, BIBFRAME) implementálása. Forrás: http://www.oszk.hu/rda-hu-munkacsoport
} 
futtatásával az intézmény repozitóriumából és az előfizetett adatbázisokból is megkapjuk a találatokat. ${ }^{44}$

A discovery rendszerek révén pedig a dokumentumszolgáltatástól eljutunk az információszolgáltatás felé, mivel a felhasználóknak gyakran nem a teljes dokumentumra, hanem az abban fellelhető információra van szükségük, ahogy tudományterületünk hivatalos elnevezése (könyvtár- és információtudomány; Library and Information Science - LIS) is kiválóan szemlélteti. A releváns információkat pedig csak a megfelelő szakképzettséggel és gyakorlattal rendelkező könyvtárosok képesek rendszerezni és szolgáltatni.

Az információszolgáltatásnak technikai előfeltételei is vannak, mint például a könyvtár infrastrukturális felszereltsége, számítógépekkel, szoftverekkel és megfelelő tárhellyel, internetkapcsolattal való ellátottsága. Ide tartozik még, hogy milyen módon tartja a kapcsolatot az olvasóival, elérhető-e a hét minden napjának minden órájában. Alapvető elvárás az online jelenlét, a jól felépített, átlátható honlap, a közösségi platformok használata, az íméles megkeresés mellett a csetelési lehetőség akár Skype-on, Messengeren vagy közvetlenül a honlapon. Mindezek az információhoz való azonnali hozzáférést segítik elő.

A könyvtár ideális esetben a település központjában, de mindenképpen jól megközelíthető helyen található. Az épület méreteit, tagolását alapvetően befolyásolja a potenciális olvasótábor létszáma és összetétele, illetve a tervezett szolgáltatások köre, ezért - ha lehetőségünk van - mindezek ismeretével rendezzük be a később is könnyen alakítható tereket.

A fenntarthatóság és a zöldkönyvtári szemlélet szintén hangsúlyossá, tudatossá vált az épületek ki-, illetve átalakításakor. Komoly eredmény, hogy a tatabányai József Attila Megyei és Városi Könyvtár 2018-ban, a kiskunfélegyházi Petöfi Sándor Városi Könyvtár 2019-ben, majd az Óbudai Platán Könyvtár - Ezüsthegyi Könyvtár 2020-ban lett díjazott az IFLA - ENSULIB (Environment, Sustainability and Libraries Section's - Kör-

\footnotetext{
${ }^{44}$ ELTEFIND - Megújult az online katalógus. Forrás: https://www.konyvtar.elte.hu/hu/ cikk/eltefind-megujult-az-online-katalogus Az ELTEfind elérhető: opac.elte.hu, katalogus. elte.hu. Az ELTE Egyetemi Könyvtár az ELTE gyakorlóiskolái számára külön felületet is biztosít: https://gimikatalogus.elte.hu
} 
nyezetvédelmi, Fenntarthatósági és Könyvtárak Speciális Érdeklődésű Csoportja) pályázatán. ${ }^{45}$

A könyvtár az olvasás és információszerzés mellett a tanulás, az alkotás, a kreativitás, az élményszerzés helye. Ahhoz, hogy mindezen elvárásnak meg tudjon felelni, szükség van a szolgálni kívánt közösség bevonására, az együtt gondolkodásra. A közösségvezérelt könyvtármodell eszközével az emberek azért válnak aktív látogatóvá, mert részt vesznek a programok és szolgáltatások kialakításában, új épület esetén akár már annak tervezési folyamatában.

Az otthon, az iskola és/vagy a munkahely mellett a könyvtár - Ray Oldenburg szavaival - mint „harmadik hely” biztosítja és segíti elő a társadalmi kapcsolatok kiépítését, elmélyítését. Közösségi térként lehetőséget teremt a személyes találkozásokra, a generációk közötti kapcsolatteremtésre, a helyi gazdaság élénkítésére. Utóbbi előfeltétele a környéken található egyéb kulturális intézményekkel, kávézókkal, üzletekkel ápolt partneri viszony. Az iskolai könyvtár az iskolán belül is képes önálló harmadik helylyé válni, ahol a diákok szabadidős tevékenységük vagy épp tanulás közben is lehetnek kicsit zajosabbak, biztonságban érezve magukat fejleszthetik szociális és egyéb képességeiket.

A kulturális törvény alapján a nyilvános könyvtár mindenki számára hozzáférést biztosít a könyvtár tereihez és az információhoz. ${ }^{46} \mathrm{Az}$ esélyegyenlöségi törvény (Ebktv.) ${ }^{47}$ tiltja a hátrányos megkülönböztetést, azonban amikor az egyetemes hozzáférésre gondolunk, leggyakrabban a fogyatékkal élők, mint a mozgás-, látás- és hallássérültek kerülnek a figyelem középpontjába. Az egyetemes tervezés arra helyezi a hangsúlyt, hogy már eleve úgy kell kialakítani a szolgáltatásokat és a tereket, hogy az valóban mindenki számára hozzáférhető legyen, akár a legkisebb adaptáció nélkül. Óhatatlanul felmerülnek speciális igények, mint például indukciós hurok alkalmazása a hangok felerősítésére hallássérült olvasók számára. A látássérült felhasználókon kívül az autizmussal élő látogatókat is segíti az elö-

${ }^{45}$ Zöld könyvtári díj, 2020. Forrás: https://mke.info.hu/blog/2020/03/zold-konyvtar-dij2020-evi-magyarorszagi-dijazottja; Az Óbudai Ezüsthegyi Könyvtár pályázati anyaga. Forrás: https://www.ifla.org/files/assets/environmental-sustainability-and-libraries/documents/ ezusthegy-library.pdf

46 1997. évi CXL. törvény 1., 4. és 54 . \$

${ }^{47}$ 2003. évi CXXV. törvény az egyenlő bánásmódról és az esélyegyenlőség előmozdításáról. Forrás: https://net.jogtar.hu/jogszabaly?docid=a0300125.tv\&timeshift=20210301 
zetes tájékozódásban az intézmény honlapján elhelyezett hangostérkép. ${ }^{48}$ A könyvtárról készített és a honlapon, valamint az intézmény falain elhelyezett térképek minden felhasználó számára hasznos segítséget nyújtanak. A honlapok és az elektronikus könyvtárak akadálymentesítését számos nemzetközi és hazai jogszabály támogatja és szabályozza, így a weblapok tervezésekor nem csak a látható tartalmakat kell sorra venni, hanem azokat az egyéb, láthatatlan elemeket is, amelyek megkönnyítik a gyengénlátók olvasási és információkeresési tevékenységét, valamint lehetővé teszik a felolvasó szoftverek működését.

Az esélyegyenlőség és a fogyatékkal élők könyvtári ellátása az intézmény szociális funkcióihoz kapcsolódik, amelyek elsősorban a közkönyvtárak, valamint az iskolai könyvtárak számára jelentenek komoly feladatot. Ez természetesen véletlenül sem jelenti azt, hogy más könyvtártípusokban ne lenne szükség speciális szolgáltatásokra, a rászorulókkal való különleges törődésre, e téren képzett munkatársakra. A hátrányos helyzetű gyermekek, az elmagányosodott időskorúak, a munkanélküliek vagy hajléktalanok a praktikus információs igényeik mellett gyakran a könyvtár már említett közösségi, befogadó szelleme miatt is felkeresik az intézményeket. A szociális funkció a társadalom perifériáin lévő csoportokhoz kötődik, akik egészségi, pszichés, gazdasági vagy más okokból kerülnek hátrányos helyzetbe.

Az utóbbi évtizedekben a könyvtárak meghatározó feladatai közé került a könyvtárhasználók digitális írástudásának, információs műveltségének, valamint az egész életen át tartó tanulásnak az elősegítése, aminek szerves része az olvasás- és szövegértés-fejlesztés, a könyvtárhasználati, illetve a legalapvetőbb számítógépkezelési ismeretek átadása. A felsorolt területek minőségi fejlesztéséhez a könyvtárak könyvtárpedagógiai foglalkozásokkal tudnak hozzájárulni, amelyek elsődleges színhelye az iskolai könyvtár, de bizonyos szinten minden könyvtártípusban felmerül a használóképzés iránti igény. ${ }^{49}$

A Széchenyi 2020 fejlesztési terv keretében a „Múzeumi és könyvtári fejlesztések mindenkinek" címü program országos hatókörü könyvtári

${ }^{48}$ Országos Széchényi Könyvtár hangostérképe a látássérültek számára. Forrás: http:// www.oszk.hu/sites/default/files/attekinto.mp3

${ }^{49}$ CSÍK Tibor (szerk.): Könyvtár és iskola: tanulmányok. Budapest, ELTE BTK Könyvtárés Információtudományi Intézet, 2020. 222 p. Forrás: https://doi.org/10.21862/978-963489-189-5 
projektje volt „Az én könyvtáram”, melynek egyik részprogramja arra irányult, hogy a közkönyvtári dolgozók is képessé váljanak olyan foglalkozások tervezésére és megtartására, amelyek az iskolák és iskolai könyvtárak mellett, illetve velük együttmüködve fejlesztik a gyerekek kompetenciáit. A tehetség kibontakoztatása, a tanulási nehézségek leküzdése, valamint az utóbbival szoros összefüggésben a közoktatásból való lemorzsolódás csökkentése a közkönyvtárakban is folyamatosan elérendő cél. ${ }^{50} \mathrm{Az}$ említett kompetenciák mellett stratégiai feladat az állampolgárok pénzügyi ismereteinek bővítése a pénzügyi tudatosság növelése érdekében. A mindennapjainkat meghatározó pénzügyi döntésekhez, a vállalkozásfejlesztéshez stb. nélkülözhetetlenek bizonyos gazdálkodási és forrásszerzési tapasztalatok, melyek átadásába a könyvtárak szintén be tudnak kapcsolódni. Az akár személyre szabott, egyéni oktatást és segítségnyújtást kínálja több könyvtár „Foglalj könyvtárost!” szolgáltatása. ${ }^{51}$

A fenti célokat is támogatja a 2016-tól zajló Országos Könyvtári Rendszer Projekt, mely hozzájárul a hagyományos és új médiumok hosszú távú megőrzéséhez, a felhasználói elvárásoknak való megfeleléshez, a digitális technológiák minél hatékonyabb alkalmazásához. A projekt részeként nem csak az OSZK integrált könyvtári rendszere újul meg az Országos Könyvtári Platform (OKP) bevezetésével, hanem a digitalizálási munkálatok eredményeinek biztonságos tárolása és szolgáltatása is megoldódhat.

Az elektronikus tartalmak előállításához és szolgáltatásához, a kulturális örökség megőrzéséhez szükséges digitalizálási alapismeretekről a következő fejezetben szólunk részletesebben.

\footnotetext{
${ }^{50}$ „Az én könyvtáram” program. Forrás: http://www.azenkonyvtaram.hu

51 Például Metropolitan Egyetem Könyvtára. Forrás: https://www.metropolitan.hu/ foglalj-konyvtarost; Kölcsönözz ki egy könyvtárost! A Szegedi Tudományegyetem Klebersberg Kuno Könyvtár szolgáltatása. Forrás: http://www.ek.szte.hu/kolcsonozz-kiegy-konyvtarost
} 


\section{Ellenőrző kérdések}

1. Csoportosítsa a könyvtári szolgáltatásokat! Melyek vonatkoznak a dokumentumokra, melyek az információra?

2. Válasszon egy könyvtártípust, és gyüjtse össze a rá jellemző szolgáltatásokat!

3. Miért tartják a helyiek a Rotterdami Központi Könyvtárat (Bibliotheek Rotterdam) tipikusan harmadik helynek?

4. Válasszon egy fogyatékkal élő csoportot, és gyüjtse össze, milyen szolgáltatásokkal tudják a könyvtárak segíteni az adott csoport információval való ellátását, hogyan tudják megkönnyíteni a könyvtárhasználatot!

5. Milyen szempontokban jelenhet meg a zöld könyvtári szemlélet?

6. Gyüjtsön érveket a prézens szolgáltatások mellett!

7. Vannak könyvtárak, ahol elérhető az önkiszolgáló kölcsönzés. Írjon pro és kontra érveket!

\section{Ajánlott irodalom}

BARÁTNÉ HAJDU Ágnes: Szakmai ismeretek és készségek - átalakuló hivatás: Válogatott könyvtártudományi tanulmányok. Budapest, Magyar Könyvtárosok Egyesülete, 2020. 270 p. Forrás: https://doi. org/10.46280\%2FKOMPKONF.2020

BODA Gáborné KÖNTÖS Nelli: Könyvtári minőségirányítás: a minőségszemlélet alkalmazása a dokumentumleírásban. In: Kiszl Péter - Boda Gáborné Köntös Nelli (szerk.): Valóságos könyvtár - könyvtári valóság. Könyvtár- és információtudományi tanulmányok 2016. Budapest, ELTE BTK Könyvtár- és Információtudományi Intézet, 2017. 139146. p. Forrás: https://edit.elte.hu/xmlui/bitstream/handle/10831/34628/ VKKV2_Boda_139_146_u.pdf

FODOR János: Útra kelt helyek - a könyvtár mint állomás. Helyismereti gyüjtemények a mobilitás és élménymegosztás tükrében. $=$ Könyvtári Figyelö, 29. (65.) évf. 4. sz. 2019. 565-573. p. Forrás: http://epa. oszk.hu/00100/00143/00358/pdf/EPA00143_konyvtari_figyelo_ 2019_04_565-573.pdf 
IFLA Guide. Útmutató a babáknak és kisgyermekeknek nyújtott könyvtári szolgáltatásokhoz. Forrás: https://www.ifla.org/files/assets/hq/ publications/professional-report/100-hu.pdf

KÁMÁN Veronika: Az iskolai könyvtár mint harmadik hely. In: Kiszl Péter Németh Katalin (szerk.): Információközvetítés és közösségépítés multifunkciós könyvtári hálózatok. Budapest, ELTE BTK Könyvtár- és Információtudományi Intézet, 2020. 237-246. p. Forrás: https://doi. org/10.21862/infkoz.237

KISZL Péter: Ki viszi át...? A könyvtárak társadalmi felelősségvállalása a digitális korban. = Tudományos és Müszaki Tájékoztatás, 64. évf. 1. sz. 2017. 1-23. p. Forrás: http://tmt.omikk.bme.hu/tmt/article/ view/774/10409

KISZL Péter: A könyvtár- és információtudományi képzés ökológiája. = Könyvtári Figyelő, 30. (66.) évf. 1. sz. 2020. 9-40. p. Forrás: https:// epa.oszk.hu/00100/00143/00359/pdf/EPA00143_konyvtari_figyelo_ 2020_01_009-040.pdf

KISZL Péter: Pénzügyi kultúra, vállalkozásfejlesztés, képzés: a könyvtár mint a gazdasági fejlődés egyik záloga. In: Kiszl Péter - Csík Tibor (szerk.): Valóságos könyvtár - könyvtári valóság. Könyvtár- és információtudományi tanulmányok 2018. Budapest, ELTE BTK Könyvtárés Információtudományi Intézet, 2018.91-101. p. Forrás: https://doi. org/10.21862/vkkv2018.91

KISZL Péter - SZÜTS Etele: Cirkuszművészeti központok tartalomszolgáltatási modelljei. = Tudományos és Müszaki Tájékoztatás, 67. évf. 3. sz. 2020. 140-160. p. Forrás: http://tmt.omikk.bme.hu/tmt/article/ download/12538/14293

KISZL Péter - BODA GÁBORNÉ KÖNTÖS Nelli (szerk.): Valóságos könyvtár - könyvtári valóság. Könyvtár- és információtudományi tanulmányok 2016. Budapest, ELTE BTK Könyvtár- és Információtudományi Intézet, 2017. 311 p. Forrás: https://edit.elte.hu/xmlui/ handle/10831/34590

KISZL Péter - CSÍK Tibor (szerk.): Valóságos könyvtár - könyvtári valóság. Könyvtár- és információtudományi tanulmányok 2018. Budapest, ELTE BTK Könyvtár- és Információtudományi Intézet, 2018. 383 p. Forrás: https://edit.elte.hu/xmlui/handle/10831/40281 
KOVÁCSNÉ KORENY Ágnes: A közösségvezérelt könyvtár elmélete és gyakorlata: In: Kiszl Péter - Csík Tibor (szerk.): Valóságos könyvtár könyvtári valóság. Könyvtár- és információtudományi tanulmányok 2018. Budapest, ELTE BTK Könyvtár- és Információtudományi Intézet, 2018. 303-310. p. Forrás: https://doi.org/10.21862/vkkv2018.303

LENDVAY Miklós: Országos Könyvtári Platform - központi könyvtári szolgáltatások együttmüködő rendszere. In: Networkshop 2020. Országos Online Konferencia. 2020. szeptember 2-4. HUNGARNET Egyesület, Budapest, 95-105. p. Forrás: https://doi.org/10.31915/ NWS.2020.10

NÉMETH Katalin: A könyvtár mindenkié!? Egyetemes tervezés és autizmusbarát könyvtárak. In: Kiszl Péter - Németh Katalin (szerk.): Információközvetítés és közösségépítés - multifunkciós könyvtári hálózatok. Budapest, ELTE BTK Könyvtár- és Információtudományi Intézet, 2020. 203-213. p. Forrás: https://doi.org/10.21862/infkoz.203

NÉMETH Katalin: Többnyelvü keresési lehetőségek az online könyvtári katalógusokban. In: Kiszl Péter - Csík Tibor (szerk.): Valóságos könyvtár könyvtári valóság. Könyvtár- és információtudományi tanulmányok 2018. Budapest, ELTE BTK Könyvtár- és Információtudományi Intézet, 2018. 199-206. p. Forrás: https://doi.org/10.21862/vkkv2018.199

NÉMETH Katalin - SENKEI-KIS Zoltán: Könyvtár és könyvtároskép Az én könyvtáram program könyvtáros portfóliói alapján. In: Módszertani mozaikok: kutatások és válogatott tanulmányok gyüjteménye. Budapest, Fővárosi Szabó Ervin Könyvtár, 2020. 361-374. p. Forrás: https://bit.ly/3aY5mq8

RÁCZ Ágnes: Országos Könyvtári Platform. A nemzeti könyvtár és a központi szolgáltatások informatikai megújításának programja. = Könyvtári Figyelő, 28. (64.) évf. 1. sz. 2018. 9-17. p. Forrás: http:// epa.oszk.hu/00100/00143/00350/pdf/EPA00143_konyvtari_ figyelo_2018_01_009-017.pdf 


\section{DIGITALIZÁLÁSI PROJEKT TERVEZÉSE}

\section{Könyvtári digitalizálás}

A közgyüjteményi szféra a tudásalapú társadalom egyik legfontosabb tartalomszolgáltatója. A felhasználók és a gyüjteménygazdák közös érdeke biztosítani a lehető legteljesebb körü és a legszabadabb formában történő hozzáférést a kulturális javakhoz. Ebben a folyamatban nagyon nagy elörelépést jelent a digitális világ eszközrendszere.

A könyvtárak számára a digitális világ a lehetőségeken túl újabb kihívásokat is jelent. A könyvtáraknak a világ minden táján proaktívan kell szembenézniük a felhasználók igényeinek változásával, és ezekre azonnali válaszokat kell nyújtaniuk. Nincs ez másképp a könyvtári digitalizálás terén sem. A társadalom egyre inkább elvárja, hogy a könyvtárak az állományukat digitális formában is a felhasználók rendelkezésére bocsássák. Ma már minden könyvtár tudatában van annak, hogy a gyüjtemények és a digitális technikák közötti kapcsolat olyan új szakaszba lépett, amelyben a legfontosabb kérdés már nem az, hogy a felhasználók digitális kommunikáció útján hozzáférjenek a katalógusokhoz, hanem sokkal inkább az, hogy a gyüjtemények tartalmát elérhetővé tegyék az interneten keresztül.

A hazai kulturálisörökség-szektor előtt álló egyik legnagyobb kihívás az analóg formában lévő dokumentumok digitalizálása, majd a digitálisan született dokumentumokkal együtt a hosszú távú megőrzésük biztosítása, továbbá a digitális tartalmak szolgáltatása. Ahhoz azonban, hogy ez egy korszerü, felhasználóbarát környezetben valósuljon meg, sok esetben a könyvtárak működési és szolgáltatási rendszerének újragondolására is szükség van.

Nézzük meg, melyek azok a közös megközelítési szempontok, amelyekhez a könyvtári digitalizálási programok során ragaszkodnunk kell:

- Dokumentumait a könyvtár köteles épségben megőrizni, szakszerü kezelésükről, megóvásukról gondoskodni.

- A könyvtárak a dokumentumgyüjteményeikhez szolgáltatásokat építenek ki, ezeken a szolgáltatásokon keresztül érik el a felhasználókat, 
és tudnak velük kapcsolatot teremteni gyüjteményeik megismertetése érdekében. A szolgáltatásai által a könyvtár köteles (szigorúan szabályozott feltételek mellett) hozzáférést biztosítani a tartalmakhoz, és ezáltal minél szélesebb körben elérni a felhasználókat.

- A könyvtári digitalizálás fő célja, hogy a digitalizálás során keletkezett digitális másolat tükrözze az eredeti dokumentum komplexitását, és biztosítsa annak a lehető legsokrétübb társadalmi hasznosítását.

- A digitalizálás fó célja a megőrzés, és - amennyiben ennek feltételei fennállnak - a tartalomszolgáltatás.

- A digitalizálás által hozzáadott értéket teremtünk, melynek során az oktatás és a tudományos kutatás támogatása elsődleges szempont.

- Igazodni kell az alább röviden ismertetett nemzetközi és hazai stratégiai dokumentumokhoz.

\section{Stratégiai környezet}

Az utóbbi időben a könyvtári világban is egyre erőteljesebben jelentkezik az igény mind a koncepcionális, mind az intézményi stratégiák létrehozására és ezek összehangolására.

A digitalizálási kezdeményezések költséghatékonyságának és minőségének javítása érdekében egységes és jól működő irányelvekre és a bevált gyakorlatokból vett példákra, továbbá olyan hosszú távon is fenntartható ajánlásokra van szükség, amelyek segítik a koordinációt és megnövelik a digitalizálási tevékenységek értékét. A körülöttünk lévő intézmények müködési koncepcióinak, programjainak és projektjeikre vonatkozó aktuális gyakorlataiknak ismerete is a hatékony közös munkát segíti. (Az összefogás eredményességét jól példázza a Fehér Könyv. Módszertani útmutató a közgyüjteményi kulturális örökség digitalizálásához és közzétételéhez ${ }^{52}$ című kiadvány, mely több közgyüjtemény közös munkájaként jött létre.) Népszerűsíteni kell a közös működtetést támogató szabványok alkalmazását, melyek elősegítik, hogy a digitalizált erőforrásokhoz való hozzáférés országszerte javuljon. (E törekvés támogatására és előmozdítására jött létre

${ }^{52}$ KÓMÁR Éva - BÁNKI Zsolt (szerk.): Fehér Könyv. Módszertani útmutató a közgyűjteményi kulturális örökség digitalizálásához és közzétételéhez. Budapest, Emberi Erőforrások Minisztériuma, 2019. Forrás: https://mnl.gov.hu/sites/default/files/feher_konyv_0.pdf 
2015-ben az országos Könyvtári Szabványositási Bizottság,,53 majd pedig 2020-ban a Könyvtári Intézetben a Könyvtári Szabványositási Iroda. ${ }^{54}$ )

A következőkben összegyüjtöttük azokat a nemzetközi és hazai stratégiai dokumentumokat, amelyek egyrész előírják, másrészt segítik a digitalizálási programok különböző intézményekre kiterjedő koordinálását, és iránymutatásul szolgálnak a hatékony és egységes munkavégzéshez.

\section{Európai uniós stratégiai dokumentumok}

\section{Lundi Alapelvek (2001)}

Az Európai Unió tagállamainak képviselöi és szakértői 2001-ben megalkották a Lundi alapelveket, amelyek megalapozták az európai kulturális örökség digitalizálásának irányait. Az aláírók deklarálták, hogy „Európa kulturális és tudományos tudáskincset hordozó forrásai egyfajta sajátos közvagyont képeznek, belőlük áll össze sokszínü társadalmaink kollektív és egyre gyarapodó emlékezete, amely egyben szilárd alapul is szolgál a digitális tartalomipar fejlődéséhez." 55 A digitalizálás a kulturális örökség hozzáférhetőségét és fenntarthatóságát, továbbá a kulturális sokszínüséget, az oktatást és a tartalomipar támogatását biztosítja. A szakértők egyben felhívták a figyelmet a digitalizálás problémáira (elaprózódás, elavulás, szellemi tulajdonjogok, gyorsan változó technológia), és máig érvényes alapelveket fogalmaztak meg a bevált gyakorlatokról, az optimális megjelenésről, az aggregációról és a hozzáférhetőségről.

\section{Pármai Charta (2003)}

Az Olasz Kulturális Minisztérium irányításával 2002-ben hozták létre hét tagállam közremüködésével (2004-ben újonnan csatlakozó tagállamokkal bővült a résztvevő országok száma) a MINERVA Projektet, melynek célja a kulturális örökség digitalizálásának összehangolása és egy olyan európai adatbázis létrehozásának előkészítése volt, amelyben az európai kulturális

\footnotetext{
${ }^{53}$ Könyvtári Szabványosítási Bizottság. http://www.oszk.hu/orszagos-konyvtari-szabvanyositasi-bizottsag

${ }^{54}$ Országos Széchényi Könyvtár, Könyvtári Intézet - Szervezeti ábra. Forrás: https://www. ki.oszk.hu/rolunk/szervezet

${ }^{55}$ HEGYKÖZI Ilona: A digitalizálási munkálatok összehangolása az EU-ban. Lundi alapelvek. = Tudományos és Műszaki Tájékoztatás, 50. évf. 11. sz. 2003. 465-468. p. Forrás: https://tmt.omikk.bme.hu/tmt/article/view/2081/3107
} 
örökség dokumentumai közösen kereshetők. A digitalizálással kapcsolatos fó feladatokat tíz pontban fogalmazták meg, melyek érintették az új technológiák intelligens felhasználását, a szellemi tulajdonjogokat, a hozzáférhetőséget, valamint a digitalizálási minőségnek, a közös müködtetésnek (interoperabilitás, szabványok, nyilvántartások, többnyelvűség), valamint a nemzeti és nemzetközi együttműködésnek a témakörét. ${ }^{56}$

\section{Európai Digitális Menetrend (Digital Agenda) (2010)}

Az Európai Digitális Menetrend az információs és kommunikációs technológiákban (IKT) rejlő lehetőségek hatékonyabb kiaknázását javasolja az innováció, a gazdasági növekedés és a haladás előmozdítása érdekében. A tisztességes, nyílt és biztonságos digitális környezet biztosítása érdekében az Európai Bizottság három pillérre építette a digitális egységes piaci stratégiát:

- Európa-szerte a digitális termékekhez és szolgáltatásokhoz való jobb hozzáférés biztosítása a fogyasztók és a vállalkozások számára;

- a digitális hálózatok és szolgáltatások fellendülését elősegítő feltételek megteremtése;

- a digitális gazdaság növekedési potenciáljának maximalizálása.

A közgyüjteményekre háruló feladatok egyik kulcsterülete Európa kulturális emlékeinek digitalizálása és megőrzése. Az iránymutatás szerint ide tartoznak a nyomtatott dokumentumok (könyvek, periodikák), fényképek, mütárgyak, levéltári iratok, hangfelvételek, audiovizuális dokumentumok, műemlékek és a régészeti lelőhelyek. ${ }^{57}$

\section{Az Európai Bizottság ajánlása (2011)}

A kulturális tartalmak digitalizálásáról és online hozzáférhetőségéről, valamint a digitális megőrzésről az Európai Bizottság először 2006-ban fogalmazott meg ajánlásokat, amelyeket a későbbi években időről időre aktualizáltak. (Az Európai Bizottság kétévente kér országjelentést az egyes tagállamoktól, az ajánlás adaptálásának eredményeiről.)

Az ajánlás főbb pontjai a digitalizálás szervezési és finanszírozási kérdéseivel, a köztulajdonban lévő (public domain), illetve szerzői jogvédelem

\footnotetext{
${ }^{56}$ Pármai Charta. Forrás: http://www.mek.oszk.hu/minerva/html/dok/parmai_charta.htm ${ }^{57}$ Az európai digitális menetrend. Forrás: https://www.europarl.europa.eu/factsheets/hu/ sheet/64/az-europai-digitalis-menetrend
} 
alatt álló tartalmak digitalizálásával és online hozzáférhetőségével, a digitális megőrzés kérdéseivel, valamint az Europeanaval foglalkoztak stratégiai szinten. Az Europeanát, Európa digitális könyvtárát, archívumát és múzeumát 2008. november 20-án indították útjára. Az Europeana platform fejlődése nagymértékben függ attól, milyen módon látják el tartalommal a tagállamok és azok kulturális intézményei, és növelik ismertségét a polgárok körében. Az Európai Bizottság ajánlása kimondja, hogy az erre irányuló intézkedéseket támogatni kell, és részletesen kidolgozott tervvel ösztönzi a kulturális intézményeket, hogy járuljanak hozzá az Europeana további fejlesztéséhez. ${ }^{58}$

Az indulása óta eltelt közel másfél évtized alatt az Europeana csapatához európai archívumok, könyvtárak és múzeumok ezrei csatlakoztak. 2021 elején az Europeana Collections összesen több mint 50 millió digitalizált mühöz (könyv, zenemű, műalkotás stb.) biztosít hozzáférést. ${ }^{59}$

\section{Az Európai Parlament és a Tanács 2013/37/EU irányelve (2013) a köz- szféra információinak felhasználásáról}

A közszféra információinak minél szélesebb körü felhasználására vonatkozó szabályok első csoportjának 2003-ban történt elfogadása óta a világban ugrásszerủen megnövekedett a nyilvános adatok mennyisége, az új típusú adatok keletkezése és begyüjtése. Ezzel párhuzamosan az adatok elemzése, feltárása és feldolgozása területén folyamatos technológiai fejlödésnek lehetünk tanúi. Ez a gyors ütemü technológiai fejlődés új szolgáltatások és új alkalmazások megjelenését teszi lehetővé, amelyek az adatok felhasználásán, összesítésén és összevetésén alapulnak. Ennek érdekében dolgozta ki az EU a közszférában keletkező információk felhasználását szorgalmazó irányelvét. A szükséges lépések elodázása azzal a kockázattal is jár, hogy az EU nem lesz képes az adatok további felhasználása kínálta gazdasági és társadalmi lehetőségeket megfelelő módon kiaknázni. ${ }^{60}$

\footnotetext{
${ }^{58}$ A Bizottság ajánlása (2011. október 27.) a kulturális anyagok digitalizálásáról és online hozzáférhetőségéről, valamint a digitális megőrzésről (2011/711/EU). Forrás: https://eurlex.europa.eu/legal-content/HU/TXT/PDF/?uri=CELEX:32011H0711\&from=HU

${ }^{59}$ About Europeana. Forrás: https://www.europeana.eu/hu/about-us

${ }^{60}$ Az Európai Parlament és a Tanács 2013/37/EU irányelve (2013. június 26.) a közszféra információinak további felhasználásáról szóló 2003/98/EK irányelv módosításáról (EGTvonatkozású szöveg). Forrás: https://eur-lex.europa.eu/legal-content/HU/TXT/PDF/?uri $=$ CELEX:32013L0037\&from $=\mathrm{HU}$
} 
Az Európai Unió Nyílt Adat Stratégiája a nyílt hozzáférésủ adatokról és a közszféra információinak további felhasználásáról (2019)

A szakértők úgy vélték, hogy „uniós szintű fellépésre van szükség a közszféra információinak és a közpénzből finanszírozott információknak a széles körü, Unió-szerte történő további felhasználása tekintetében továbbra is fennálló, és újonnan megjelenő akadályok elhárítása, a jogalkotási keretnek a digitális technológiai fejleményekhez való felzárkóztatása és a digitális innováció - különösen a mesterséges intelligencia tekintetében történő - további ösztönzése érdekében." A stratégia - többek között - szabályozza a könyvtárak és a magánpartnerek közötti kulturális erőforrások digitalizálására kiterjedő együttműködési megállapodásokat, mivel a gyakorlat azt mutatja, hogy az ilyen „köz-magán társulások” megkönnyíthetik a kulturális gyűjtemények észszerü felhasználását, és így a polgárok számára is gyorsabb hozzáférést biztosíthatnak a kulturális örökséghez. ${ }^{61}$

\section{Magyarországi stratégiai dokumentumok}

Az alábbiakban a közgyűjteményi digitalizálás irányait meghatározó legújabb és legfontosabb magyarországi dokumentumokat ismertetjük röviden.

Nemzeti Infokommunikációs Stratégia (2014-2020)

Az Európai Digitális Menetrendben megfogalmazott uniós elvárások mentén alakult ki a Nemzeti Infokommunikációs Stratégia. A magyar információs társadalom kialakítása érdekében számos stratégia jelent meg korábban hazánkban: ennek legújabb tagja a 2020 végén lejárt infokommunikációs stratégia, melynek határozott célja a digitális állam által a felhasználók digitális életminőségének javítására szolgáló elektronikus szolgáltatások biztosítása az egész társadalom számára. A stratégia nagy hangsúlyt fektet az infokommunikációs technológiák fejlesztésére, a lakossági elektronikus közigazgatási szolgáltatásokra, valamint az állam vagy mások által nyújtott

${ }^{61}$ Az Európai Parlament és a Tanács (EU) 2019/1024 irányelve (2019. június 20.) a nyílt hozzáférésű adatokról és a közszféra információinak további felhasználásáról Preambulum 3. bekezdés. Forrás: https://eur-lex.europa.eu/legal-content/HU/TXT/PDF/?uri=CE LEX:32019L1024\&from $=\mathrm{HU}$ 
egyéb elektronikus szolgáltatások: az egészségügyi, oktatási, könyvtári és a kulturális örökséget érintő szolgáltatások fejlesztésére. ${ }^{62}$

A stratégia megállapításaiból az következik, hogy a digitális kompetenciák fejlesztésében meghatározó szerepet kapnak a közgyüjtemények, azon belül a könyvtárak. A lakosság digitális kompetenciájának növelése a digitális írástudatlanság és a digitális megosztottság mértékének csökkentésével valósulhat meg. Ezen kompetenciák fejlesztésével az elektronikus tartalmak befogadása könnyebbé válik a lakosság és a fejlődő vállalkozások számára. A könyvtárak mindehhez a településen belüli megfelelő elhelyezkedésükkel, belső tereik optimális kialakításával, digitálisan hozzáférhető gyűjteményeik növelésével és a könyvtárosok szakmai felkészültségével tudnak hozzájárulni.

Digitális Jólét Program (DJP) (2015), Digitális Jólét Program 2.0 (2017) 2015 őszén lezárult az Internetkon, az internetről és a digitális fejlesztésről szóló nemzeti konzultáció, melynek eredményeként jött létre a Digitális Jólét Program..$^{63} \mathrm{Az}$ előkészítés alapvető kérdései a mobil és vezetékes hálózatok fejlettségére, a digitális tartalmak hozzáférhetőségére vonatkoztak. A cél, a technológiai fejlődéshez való felzárkózás után, a digitalizáció társadalmi és gazdasági hatásainak optimalizálása és kiaknázása. Ennek a célnak a megvalósítási folyamatában a közgyüjtemények, mint alapvető, meghatározó és megbízható tartalomszolgáltatók szerepelnek. A program akkor tekinthető eredményesnek, ha megvalósul a megfelelő tartalom megfelelő időben való biztosítása a felhasználó számára. Mindehhez természetesen elengedhetetlen, hogy a felhasználó rendelkezzen a digitális írástudás megfelelő kompetenciájával ahhoz, hogy elérje a digitális tartalmakat. Ennek elérését segítette elő a Digitális Jólét Program kibővített, 2.0-s verziója, melyben a digitális infrastruktúra elérésének támogatása és a digitális kompetencia fejlesztése kapta a föszerepet. Több mint 20 új fejlesztési programot tartalmazó stratégia a magyar gazdaság, az állami müködés és a magyar társadalom digitális fejlesztésének szinte valamennyi

\footnotetext{
${ }^{62}$ Nemzeti Infokommunikációs Stratégia 2014-2020. Forrás: https://nisz.hu/sites/default/ files/u1/nemzeti_infokommunikacios_strategia_2014_2020.pdf

${ }^{63}$ A Kormány 127/2017. (VI. 8.) Korm. rendelete a Digitális Jólét Program végrehajtásával összefüggő egyes feladatokról, valamint a Kormányzati Informatikai Fejlesztési Ügynökségről szóló 268/2010. (XII. 3.) Korm. rendelet módosításáról. Forrás: https://bit. ly/3qigkwZ
} 
területén megfogalmazza a digitalizációt támogató programokat. (Támogatott fejlesztések például: Digitális Jólét Szoftver Alapcsomag, Szupergyors Internet Program, Digitális Jólét Klub program, Okos Város és Okos Térség mintaprojekt, Iparágak digitalizációjának módszertani támogatása, Digitális Egészségipar-fejlesztési Stratégia, Közadat újrahasznosítás, nemzeti adatpolitika). ${ }^{64}$

\section{Magyarország Digitális Oktatási Stratégiája (DOS) (2016)}

A Digitális Jólét Programon belül kidolgozott DOS célja az információkezelés képességének elsajátítása a köz- és a felsőoktatásban. ${ }^{65} \mathrm{~A}$ stratégia törekvéseinek megvalósításához szükségszerü, hogy a közgyüjtemények munkája permanensen összefonódjon a digitális oktatással, hiszen a közgyüjtemények megfelelő humánerőforrással és infrastrukturális feltételekkel rendelkeznek ahhoz, hogy aktív szerepet vállaljanak új típusú tanulási és oktatási segédletek kialakításában, létrehozva ezzel egy innovatív minőségi digitális kulturális környezetet.

\section{Közgyüjteményi Digitalizálási Stratégia (KDS) (2017-2025)}

A kormányzat által kidolgozott KDS célja, hogy a társadalom minél szélesebb köre számára biztosítsa az akadálytalan hozzáférést a memóriaintézmények digitalizált tartalmaihoz. A gyüjtemények digitalizálását és hozzáférhetővé tételét az alapvető állományvédelmi szempontokon túl az indokolja, hogy általa lehetővé válik a magyar nemzeti örökség terjesztése, az állampolgárok digitális kompetenciáinak fejlődése, mindezek következtében viszont javul a digitális kulturális tartalmakat használók életminősége és komfortérzete.

A cél az, hogy a közgyűjtemények a kulturális örökség őrzőiből a kulturális örökség megosztóivá váljanak, és valamennyi tevékenységükkel kapcsolódjanak a digitális ökoszisztémához. A tartalomszolgáltatásban a szolgáltatásorientált szemléletnek kell érvényesülnie, amely egyúttal a tar-

${ }^{64}$ A Digitális Jólét Program 2.0, Budapest, 2017. Forrás: https://digitalisjoletprogram.hu/ files/58/f4/58f45e44c4ebd9e53f82f56d5f44c824.pdf

${ }^{65} 1536 / 2016$. (X. 13.) Korm. határozat a köznevelési, a szakképzési, a felsőoktatási és a felnőttképzési rendszer digitális átalakításáról és Magyarország Digitális Oktatási Stratégiájáról Forrás: https://net.jogtar.hu/jogszabaly?docid=A16H1536.KOR\& txtreferer $=00000001 . t x t$ 
talomszolgáltatás minőségi és mennyiségi javulását eredményezi. A digitalizálás legyen eszköz ahhoz, hogy az emberek könnyebben juthassanak hozzá az egyéni élethelyzetüket javító tudáshoz. Mindezen célok eléréséhez szükséges a közgyüjteményi tartalomszolgáltatás és az oktatás minél szorosabb összekapcsolása, mely szintén a KDS kiemelt célkitüzése.

Az infrastrukturális fejlesztéseknek hála, az adatok és információk internetes elérése ma már szinte mindenki számára adott; a közgyüjtemények szerepe ebben az esetben a közzétett tartalom hitelességének igazolhatóságával válik kiemelkedővé. A nyilvános tartalmak társadalmi hasznosulása a hozzáférés bővítésével nő; várhatóan a közgyüjtemények iránt nagyobb lesz az érdeklődés, így társadalmi megítélésük pozitív irányba változik. A létrejövő tartalmak könnyebb megtalálhatósága és felhasználhatósága érdekében szerepel a célok között a Nemzeti Adattár Projekt (NAP) megvalósítása (1. ábra). A célok eléréséhez szükség van az országos szintű együttmüködés kialakítására a digitalizálás területén. ${ }^{66}$

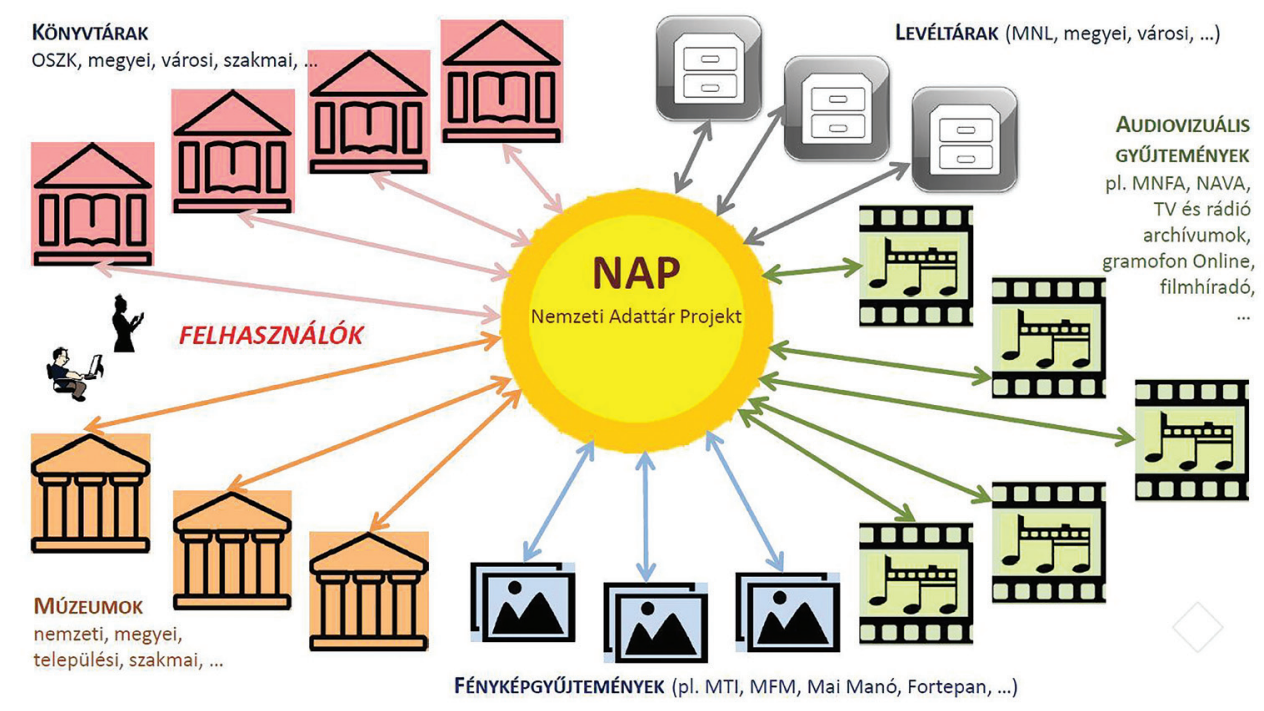

1. ábra: Nemzeti Adattár Program (Forrás: Közgyüjteményi Digitalizálási Stratégia ${ }^{67}$ )

\footnotetext{
${ }^{66}$ Közgyűjteményi Digitalizálási Stratégia (2017-2025) Forrás: https://digitalisjoletprogram.hu/files/27/c4/27c41541fb75cfb0bfd4ceb02385fb4e.pdf ${ }^{67}$ Uo. 50. p.
} 
A könyvtárak digitalizálási tevékenysége számára iránymutató dokumentumnak tekinthetjük más nemzetek digitalizálási stratégiáit is. A nemzetközi jó gyakorlatok tanulmányozásának és alkalmazásának jótékony hatása megkérdőjelezhetetlen.

\section{A digitalizálás fogalma}

A „digitalizálás” fogalmát többféle értelemben használják a stratégiákban és a szakmai diskurzusokban.

Beszélhetünk társadalomtörténeti szempontról, amely megközelítés alatt digitalizálásnak azt a folyamatot tekintjük, amelyben végbemegy a digitális korba történő átmenet (digitalizáció, digitális átállás, digitális korszakváltás, elektronizáció stb.). A jelenleg érvényben lévő stratégiai dokumentumok is többnyire ebben az értelemben használják a digitalizálás fogalmát.

Szűkebb, könyvtárszakmai értelemben vett digitalizáláson a könyvtári gyűjtemény tipikus részét képező, analóg információhordozókon tárolt, nyomtatott dokumentumok digitális eszközökre kódolásának, kezelésének és szolgáltatásának folyamatát értjük.

A harmadik szempont technológiai szemléletü. A digitalizálás fogalmának ez talán a legszűkebb értelemben vett megközelítési módja. Az a folyamat, amely során egy eredetileg analóg dokumentumot digitális formában leképezünk, a „dokumentum tartalmát úgy helyezzük el egy elektronikus tárolóeszközön, hogy formai és tartalmi elemeit is megőrizzük, és egyúttal számítógép segítségével feldolgozhatóvá tegyük”68 - vagyis a tartalmat átkódoljuk a számítógépek által értelmezhető nyelvre.

\section{A könyvtári digitalizálás iránymutató dokumentumai}

A könyvtári digitalizálás munkafolyamatainak megkezdése előtt alapvető kérdésekre kell választ adni, és el kell készíteni az erre vonatkozó irányadó dokumentumokat. Alapvetően három ilyen, átgondolt és jól

${ }^{68}$ SÜTHEÖ Péter: Elektronikus, digitális, virtuális könyvtárak. = Horváth Tibor - Papp István (szerk.): Könyvtárosok kézikönyve. 3. A könyvtárak rendszere. Budapest, Osiris Kiadó, 2001. 213. p. 
kidolgozott dokumentumra van szükség, amelyek megalkotása elengedhetetlen ahhoz, hogy a könyvtári digitalizálással felvállalt céljaink maradéktalanul teljesülhessenek: a digitalizálási stratégia, a digitalizálási terv és a digitalizálási szabályzat.

A könyvtár víziójának és küldetésnyilatkozatának megfelelő digitalizálási stratégia megfogalmazza a digitalizálás célját, megvalósításának stratégiai okait és az intézmény szolgáltatáspolitikájának a digitalizálási munkafolyamatokkal való összehangolását.

A könyvtári állomány és a rendelkezésre álló humánerőforrás fényében kidolgozott szolgáltatáspolitika figyelembevételével elkészített digitalizálási tervnek tartalmaznia kell, hogy a könyvtár mely állományrészeit milyen ütemterv szerint és milyen eszközökkel digitalizálja.

A digitalizálási munkafolyamatokat és az informatikai támogatást biztosító részlegek - vagy külső partner - bevonásával megalkotott digitalizálási szabályzat lefekteti a minőségi követelményeket (pl. képfelbontás, fájlformátum, karakterfelismertetés), a digitalizálás módszertanát, illetve a megvalósítás lehetőségeit és menetét (megőrzési-szolgáltatási állományok, tárhelykapacitás, egységesség kérdései).

\section{A könyvtári digitalizálás célja}

Ahhoz, hogy a könyvtár korszerü, a felhasználók igényeinek megfelelő szolgáltatásokat építsen ki, a digitalizálási munkafolyamatok megtervezésénél a későbbi digitális tartalomlétrehozás és -szolgáltatás céljait kell szem előtt tartani. A könyvtári digitalizálás céljai az alábbiak lehetnek:

- Az állományvédelmi cél vagy az új típusú megőrzés bevezetésére, vagy a biztonság növelésére irányul. Ezekben az esetekben a digitalizálás eredményeképpen az eredeti adathordozó kivonásra kerülhet a forgalomból, mert a digitális másolattal helyettesíthető, de lehetőséget biztosít az analóg objektum esetleges sérülése vagy megsemmisülése esetén a dokumentum tartalmához való hozzáférésre is.

- Az állománygyarapitás új alternatívája, amikor olyan tartalmak gyüjteménybe kerülésére van lehetőség, amelyek esetében az analóg dokumentum eredeti változatának megszerzésére a könyvtárnak nincs módja. 
- A könyvtári digitalizálás arra is lehetőséget ad, hogy új típusú szolgáltatásokat vezessünk be, hiszen a különböző intézményekben őrzött anyagok virtuális módon újra-egyesíthetőek az eredeti példányok átadása nélkül. Mindez új szolgáltatások, tematikus gyüjtemények kialakítását is eredményezheti. Az internet nyilvánosságán és a kreatív ipar támogatásán keresztül a könyvtárak szélesebb rétegekhez tudják eljuttatni a kulturális tartalmaikat. A könyvtári dokumentumok használatának lehetőségeit jelentősen kibővíti a digitális tartalomban végezhető keresés, tartalomelemzés, automatikus feldolgozás. Ezáltal növelni tudjuk a

- felhasználhatóságot és a nyilvánosságra hozott publikációk számát, amivel olyan dokumentumok válnak elérhetővé a kutatók és a laikus felhasználók számára, amelyek online tanulmányozására korábban nem volt lehetőségük.

- A digitális kulturális örökségi tartalmak az élethosszig tartó tanulás és oktatás kimeríthetetlen forrásaiként szolgálnak, erősítve ezzel a közmüvelödési, oktatási funkciót.

- A könyvtári állomány felhasználásának fizikai és időbeli korlátait leghatékonyabban a digitalizált tartalmak online elérhetőségének és szolgáltatásba helyezésének biztosítása szünteti meg, amely a távfelhasználók aktivizálását és az esélyegyenlöség növelését segíti elő. ${ }^{69}$

\section{A digitalizálás stratégiai elvei}

A könyvtári digitalizálás céljának meghatározása után az intézményi stratégiával összhangban kell megfogalmazni a digitalizálás során irányadó stratégiai alapelveket.

A társadalmi igény elve alapján például olyan gyűjteményegységek digitalizálására kerülhet sor, amelyek vagy egy intenzíven kutatott területről nyújtanak átfogó képet, vagy kiemelkedő forrásértékkel bírnak, vagy a nemzeti, illetve nemzetközi érdeklődésre számot tartó kulturális örökségi tartalom körébe tartoznak, vagy azon dokumentumok, amelyek a nemzeti

${ }^{69}$ KÓMÁR Éva - BÁNKI Zsolt: i. m. 
és/vagy a helyi identitásnak a meghatározó elemei, ezért kulturális, oktatási felhasználásuk mind tartalmi, mind esztétikai szempontból fontos.

Az elégséges adat elve szerint a digitalizálás feltételeként szabható meg, hogy a digitalizálásra szánt dokumentumok azonosításához (formai és tartalmi bibliográfiai feldolgozás) elégséges adat álljon rendelkezésre és a szolgáltatásukhoz elégséges adat (metaadat) legyen biztosítható.

Az adatmentés elve azon dokumentumok esetén alkalmazható, ahol az eredeti adathordozón lévő adatok hosszú távú megőrzése és hozzáférése csak digitalizálással oldható meg.

$\mathrm{Az}$ állományvédelmi elv figyelembevételekor azokat a dokumentumokat digitalizáljuk, amelyek folyamatos szolgáltatása nagy állagromlást okoz, ezért preventív állományvédelmi beavatkozás szükséges. A digitalizálás során csak indokolt esetben fogadható el a használatnál nagyobb állományvédelmi kockázat.

A dokumentumok digitalizálása, veszélyeztetettsége és használata közötti összefüggést a 2. ábra szemlélteti.

\begin{tabular}{|c|c|c|c|}
\hline \multirow{2}{*}{\multicolumn{2}{c|}{}} & \multicolumn{3}{|c|}{ A használat gyakorisága } \\
\cline { 2 - 5 } & Nagy & Közepes & Csekély \\
\hline \multirow{2}{*}{ Nagy } & $\begin{array}{c}\text { Azonnali } \\
\text { digitalizálás, } \\
\text { restaurálás }\end{array}$ & $\begin{array}{c}\text { Digitalizálás, } \\
\text { restaurálás }\end{array}$ & $\begin{array}{c}\text { Digitalizálás, } \\
\text { konzerválás }\end{array}$ \\
\hline Közepes & $\begin{array}{c}\text { Digitalizálás, } \\
\text { konzerválás }\end{array}$ & $\begin{array}{c}\text { Digitalizálás, } \\
\text { konzerválás }\end{array}$ & $\begin{array}{c}\text { Elhelyezés } \\
\text { védőtárolóban }\end{array}$ \\
\hline
\end{tabular}

2. ábra: A veszélyeztetettség és használat közötti összefüggés

(Forrás: Az Országos Széchényi Könyvtár digitalizálási stratégiája 2017-202570)

A gazdaságossági elv szerint figyelembe kell venni a költséghatékony digitalizálási szempontokat (digitalizálási költség - várható haszon).

\footnotetext{
${ }^{70}$ Az Országos Széchényi Könyvtár digitalizálási stratégiája 2017-2025. 25. p. Forrás: http://www.oszk.hu/sites/default/files/OSZK_DIGIT-STRAT_2017_11_27.pdf
} 
A sokféleség elve során szem előtt kell tartani az analóg információhordozók diverzitását.

Az újrahasznosithatóság elve szerint a dokumentumok digitális formában való közzététele kreatív felhasználásra teremt lehetőséget, és - adott esetben - a kereskedelmi felhasználáson keresztül hozzájárulhat a kulturális gazdaság fejlesztéséhez.

A tömeges információ elve az automatikus információkinyerési technológiák alkalmazásával a digitalizált adatokból a képi információnál magasabb feldolgozottsági szint elérését teszik lehetővé, illetve a kinyert adatok más adatokkal való összekapcsolása új információk keletkezéséhez vezethet. A tömeges információ elve esetén törekedni kell arra, hogy az összetartozó egységek együttes digitalizálása egyszerre történjen, illetve a korábban töredékesen digitalizált kulturális örökségi együtteseket lehetöség szerint kiegészítsük. ${ }^{71}$

\section{A digitalizálandó dokumentum kiválasztásának szempontjai}

A könyvtár digitalizálási tevékenységének stratégiai elvei mentén, az állomány, a rendelkezésre álló humánerőforrás és eszközkapacitás tükrében meg kell határozni a digitalizálásra szánt dokumentumok konkrét körét. A gyakorlat azt mutatja, hogy a kiválasztást az esetek nagy százalékában komoly válogatásnak kell megelőznie. A választás kritériumai a digitalizálási projekt megvalósítandó céljaitól függően különbözőek lehetnek. Léteznek azonban minden esetben megvizsgálandó, részben állományvédelmi, részben szerzői jogi, részben személyesadat-kezelési alapvető, általános szempontok:

- A digitalizálandó anyag állapotának, sérülékenységének felmérése, illetve a digitalizálás folyamán az állapot esetleges további romlásának mérlegelése. A kötéstechnikának, a kötés anyagának és állapotának a feltárása. A dokumentum teljességének vizsgálata.

\footnotetext{
${ }^{71}$ Az Országos Széchényi Könyvtár digitalizálási stratégiája 2017-2025. - A szerző által az Országos Széchényi Könyvtár illetékes munkacsoportjával közösen kidolgozott rész.
} 
- A digitalizálandó anyag jelenlegi online elérhetőségének, más gyüjteményekben való hozzáférhetőségének ellenőrzése a duplumok elkerülése és az erőforrások optimalizálása érdekében.

- A dokumentum online szolgáltatásba kerülési lehetőségeinek megvizsgálása, esetleges nehézségeinek felmérése. Az online szolgáltatásba kerülés szempontjából több dologra is szükséges felhívni a figyelmet.

- A digitális gyüjtemény kialakításával egyidőben párhuzamosan mindig végig kell gondolni a könyvtár szolgáltatáspolitikáját, különös tekintettel arra, hogy az új típusú dokumentumok gyüjteménybe kerülésével a szolgáltatások mely területei, milyen mértékben igényelnek változtatást és újrastrukturálást.

- Meg kell vizsgálni, hogy ezekhez a változtatásokhoz milyen informatikai korszerüsítésekre és szolgáltatásfejlesztésekre van szükség.

- Nyomatékosan felhívjuk a figyelmet azonban arra, hogy egy digitális gyüjtemény szolgáltatásba kerülése esetén mindezek előtt elengedhetetlen a digitalizálandó dokumentumok szerzői jogi kérdéseinek áttekintése és a jogok tisztázása.

Fontos leszögezni, hogy a szerzői jogi korlátozások minden esetben a szolgáltatásokra vonatkoznak, tehát a nyilvános könyvtár archiválási és egyéb, a szerzői jogi törvényben meghatározott célból saját dokumentumáról készíthet digitális másolatot:

„35. $\$(4)$ Nyilvános szolgáltatásokat nyújtó könyvtár, iskolai oktatás céljából [33. $\mathbb{\$}(4)$ bek.] köznevelési intézmény, szakképző intézmény és felsőoktatási intézmény, muzeális intézmény, levéltár, valamint a közgyüjteménynek minősülő kép-, illetve hangarchívum a müről másolatot készíthet, ha az jövedelemszerzés vagy jövedelemfokozás célját közvetve sem szolgálja, és a) tudományos kutatáshoz vagy archiváláshoz szükséges,

b) nyilvános könyvtári ellátás vagy a $38 . \mathbb{\$}(5)$ bekezdésében meghatározott felhasználás céljára készül,

c) megjelent mủ kisebb részéről, továbbá újság- vagy folyóiratcikkről belső intézményi célra készül."72

\footnotetext{
72 1999. évi LXXVI. törvény a szerzői jogról. Forrás: https://net.jogtar.hu/jogszabaly? docid $=99900076 . t v$
} 
Röviden tekintsük át azokat a kategóriákat, amelyeket a dokumentumok szolgáltatásba adása előtt szerzői jogi szempontból meg kell vizsgálni.

A közkincsnek ${ }^{73}$ minősülő dokumentumokat szabadon hozzáférhetővé teheti a könyvtár. Előfordulhat, hogy a hozzáférést a könyvtár szolgáltatáspolitikája, vagy akár még az esetleges szponzori szerződések is befolyásolhatják. (Példa az OSZK gyakorlatából: az egyik kiadóval kötött szponzori szerződés alapján a megállapodás keretében digitalizált - egyébként közkincsnek minősülő - műveket meghatározott ideig csak korlátozottan lehetett elérni.)

A digitális másolatkészítés archiválási és megőrzési célból jogvédett müvek esetén is megengedett, a szolgáltatás azonban korlátozott. A jogvédett művek szolgáltatási módozatai a következők:

$\diamond$ A szerzői jogi törvény lehetőséget biztosít a közgyűjteményeknek a jogvédett tartalmak megjelenítésére a könyvtár saját helyiségében elhelyezett zárt hálózatú terminálján. ${ }^{74}$

$\diamond$ Ezt a lehetőséget pontosítja és bővíti ki a dedikált hálózaton való hozzáférhetővé tétel lehetőségével a 117/2004. (IV. 28.) Korm. rendelet:

„3. $\mathbb{S}(1)$ A kedvezményezett intézmény gyüjteménye az Szjt. 38. \$-ának (5) bekezdésében meghatározott szabad felhasználás alapján történő hozzáférhetővé tétel céljából bármely más kedvezményezett intézmény gyüjteményével szabadon összekapcsolható (célrarendelt hálózatba kapcsolódás). A kedvezményezett intézmény gyüjteménye más, vele összekapcsolt kedvezményezett intézményben felállított számítógépes terminálon keresztül az igénybe vevő számára a nyilvánossághoz közvetíthető."75

\footnotetext{
${ }^{73}$ A közkincs meghatározását illetően az 1999. évi LXXVI. törvény a szerzői jogról 31-32. \$ jelent támpontot. Forrás: https://net.jogtar.hu/jogszabaly?docid=99900076.tv

${ }^{74}$ Szjt. 38. $\mathbb{S}$ (5) Forrás: https://net.jogtar.hu/jogszabaly?docid=99900076.tv

${ }^{75}$ 117/2004. (IV. 28.) Korm. rendelet a szerzői jogról szóló 1999. évi LXXVI. törvény 38. \$ának (5) bekezdésében szabályozott szabad felhasználás esetében a nyilvánosság egyes tagjaihoz való közvetítés és a számukra történő hozzáférhetővé tétel módjának és feltételeinek meghatározásáról. Forrás: https://net.jogtar.hu/jogszabaly?docid=A0400117.KOR
} 
$\diamond \quad$ A jogvédett műveken belül az árva müvek ${ }^{76}$ felhasználását a könyvtárak mindenki számára szabadon hozzáférhető módon biztosíthatják. A felhasználás előfeltételeit a 138/2014. (IV. 30.) Korm. rendelet ${ }^{77}$ szabályozza.

A könyvtári digitalizálás és digitálistartalom-szolgáltatás egyszerűsödését eredményezheti az ún. DSM irányelv ${ }^{78}$ 2021-ben esedékes átültetése a hazai jogrendbe. Az EU irányelvnek köszönhetően ugyanis mód nyílhat a kereskedelmi forgalomban nem kapható müvek kiterjesztett hatályú közös jogkezelésére.

A jogvédett e-tartalmak könyvtári kölcsönzésével kapcsolatban fontos megjegyezni, hogy a jelenlegi jogszabályi keretek lehetővé teszik az e-tartalmak elektronikus kölcsönzését a hagyományos könyvtári haszonkölcsönzés mintájára.

A könyvtárak szolgáltatási rendszerében előforduló személyesadatkezelési helyzeteket az $\mathrm{EU}$ általános adatvédelmi rendeletének elöírásai szerint kell betartani. (A GDPR néven ismertté vált jogszabály (General Data Protection Regulation - az Európai Unió általános adatvédelmi rendelete) 2016. május 24-én lépett hatályba, rendelkezéseit 2018. május 25 . napjától kell az Európai Unióban - egész pontosan az Európai Gazdasági Térség (EGT) országaiban - kötelezően és közvetlenül alkalmazni.) A Rendelet legfőbb célja, hogy az Európai Unióban egységes jogalkalmazás alakuljon ki a természetes személyeket

\footnotetext{
${ }^{76}$ Árva művek meghatározására a 2012/28/EU irányelv 2. cikkének (1) pontja, illetve a 2013. évi CLIX. törvény a szellemi tulajdonra vonatkozó egyes törvények módosításáról ad támpontot.

77 138/2014. (IV. 30.) Korm. rendelet az árva mü felhasználásának részletes szabályairól. Forrás: https://net.jogtar.hu/jogszabaly?docid=a1400138.kor

${ }^{78}$ Az Európai Parlament és a Tanács (EU) 2019/790 irányelve (2019. április 17.) a digitális egységes piacon a szerzői és szomszédos jogokról, valamint a 96/9/EK és a 2001/29/ EK irányelv módosításáról. Forrás: https://eur-lex.europa.eu/legal-content/HU/TXT/ ?uri=CELEX:32019L0790
} 
megillető alapvető jog, a személyes adataik védelme terén. ${ }^{79}$ Ezek az elöírások nem is minden esetben olyan egyértelmüek vagy könnyen értelmezhetőek. Ezen témában ajánljuk Tószegi Zsuzsanna 2019-ben a Könyvtári Figyelóben megjelent cikksorozatát, melyben nagyon alaposan tárgyalja a személyesadatkezelés szabályozását és értelmezését, továbbá összefoglalja a szabályozás könyvtárakra rótt kötelezettségeit és feladatait.

A fenti témák tárgyalásával reméljük, sikerült rávilágítanunk arra, miért állítottuk a könyvtári digitalizálásról szóló fejezet bevezetőjében, hogy a digitalizálás a könyvtárak számára épp olyan nagy lehetőség, mint amekkora feladat. Rövid összefoglalásképpen álljon itt két idézet a könyvtári gyűjtemények digitalizálásával elérendő célokról. Elsődleges a „hiteles forrásanyag nyújtása a tudományos igényű kutatás számára, amely esetben a hitelesség az eredeti (analóg) objektumokat a lehetséges legnagyobb mértékben tükröző, azokat a bennük rejlő információtartalmak közvetítése szempontjából a mindenkori felhasználó számára helyettesíteni képes digitális korpusz létrehozását jelenti”, a másodlagos cél pedig „a hiteles digitális korpuszra épülő egyéb szolgáltatások kialakítása, pl. példányok (és gyűjtemények) virtuális rekonstrukciója, az általános társadalmi információigény kielégítését célzó szolgáltatások" ${ }^{80}$ megteremtése.

Igen lényeges kérdés, hogy az olvasók megfelelő módon elérik-e a digitális tartalmakat. A digitalizálás által létrejött (vagy digitálisan született) dokumentumok bevezetése a szolgáltatási rendszerbe mindig nagy feladat, hiszen vagy egységben kell maradni a könyvtár eddigi szolgáltatási rendszerével, vagy egy új szolgáltatási struktúra és szolgáltatáspolitika kialakítására van szükség - ami sok esetben a stratégia újragondolását teszi szükségessé.

\footnotetext{
${ }^{79}$ Magyarázat a GDPR-ról. (Szerk.) Péterfalvi Attila [et al.]. Budapest, Wolters Kluwer, 2018. 24. p. Idézi: TÓSZEGI Zsuzsanna: Az Európai Unió általános adatvédelmi rendelete, a GDPR. 1. rész: Alapfogalmak, alapelvek. = Könyvtári Figyelö, 61. évf. 1. sz. 2019. 9-35. p. Forrás: https://epa.oszk.hu/00100/00143/00355/pdf/EPA00143_konyvtari_ figyelo_2019_01_009-035.pdf

${ }^{80}$ DANCS Szabolcs: A hiteles digitális másolatról és a másolati példányok bibliográfiai kezeléséről - 1. rész: Hitelesség szabványos alapokon. = Könyv, Könyvtár, Könyvtáros, 26. évf. 10. sz. 2017. 7-15. p. Forrás: http://epa.oszk.hu/01300/01367/00295/pdf/ EPA01367_3K_2017_10_007-015.pdf
} 
A közgyűjteményekben őrzött dokumentumok digitalizálását eddig is nagyon fontosnak tartották azok, akik rendszeresen használták kutatásra, tájékozódásra az online elérhető tartalmakat, továbbá azok, akik az online tartalomszolgáltatásról gondoskodtak. 2020 tavaszán a koronavírus-járvány (COVID-19) miatt hirtelen minden megváltozott: a közoktatásnak néhány óra alatt kellett átállnia a jelenlétiről a távoktatásra, amelyhez a korábbiakhoz képest összehasonlíthatatlanul több online elérhető forrásra volt szükség, így hirtelen felértékelődtek a digitális könyvtárak, a kulturális tartalmak az interneten.

2020 és 2021 a könyvtárak történetében is soha nem látott, rendkívüli időszak, hiszen a központilag elrendelt könyvtárbezárások kapcsán fokozott figyelem hárult az elmúlt évtizedekben kialakított digitális szolgáltatásokra. A könyvtártudományi szakirodalom biztosan sokat fog még foglalkozni ezzel a témával, amelyről részletes összefoglaló jelent meg a Könyvtári Figyelő 2020. évi 3. számában Bódog András tollából. A Könyvtári Intézet honlapján folyamatosan frissülő, naprakész információkat találunk egyes országok könyvtárainak járványidőszak alatti óvintézkedéseiről, tapasztalatairól és arról, hogyan tudják - legalábbis részben - fenntartani szolgáltatásaikat. ${ }^{81}$ Ugyancsak a Könyvtári Intézet gondozza a Könyvtárak. hu honlapot, ahol számos hír mellett feltüntetik azokat a könyvtárakat, amelyek országszerte rendkívüli szolgáltatásokat nyújtanak a koronavírus járvány idején a „könyv- és könyvtárínségben” szenvedők számára. A fejezet lezárásakor a Könyvtárak.hu ${ }^{82} 286$ olyan könyvtárat tartott nyilván, amely a zárvatartás alatt rendhagyó szolgáltatást nyújtott. Ha valamikor, akkor most, a COVID-19 idején tömegek érezték meg a közgyüjteményi digitalizálás és az online hozzáférhetőség áldásos hatását.

\footnotetext{
${ }^{81}$ Könyvtári Intézet - Koronavírus és a könyvtárak, 2020 őszétől - a beszámoló folyamatosan frissül! Forrás: https://ki.oszk.hu/node/9835

${ }^{82}$ Könyvtárak.hu. Forrás: https://konyvtarak.hu/index.php
} 


\section{Ellenőrző kérdések, feladatok}

1. Nevezzen meg néhány nemzetközi és hazai stratégiai dokumentumot, és fejtse ki röviden digitalizálással kapcsolatos iránymutatásaikat!

2. Határozza meg a digitalizálás stratégiai elveit!

3. Sorolja fel a digitalizálási munkafolyamat megtervezéséhez elengedhetetlen dokumentumokat!

4. Határozza meg, mit tartalmaz a digitalizálási szabályzat!

5. Fejtse ki, milyen egyéb könyvtárvezetési/menedzsmenti szempontokat kell figyelembe venni a digitalizálási stratégia készítésekor!

6. Sorolja fel, és fejtse ki, milyen céljai lehetnek a könyvtári digitalizálásnak!

7. Milyen módon segíti a könyvtári digitalizálás a távfelhasználók bevonását és az esélyegyenlőség növelését?

8. Mi az összefüggés a könyvtári digitalizálás és az állománygyarapítás között?

9. Mit jelent a digitalizálandó anyagok kiválasztásánál a tömeges információ elve?

10. Sorolja fel, milyen kérdéseket kell megvizsgálni a digitális dokumentumok online szolgáltatásba kerülésekor!

11. Igaz-e az az állítás, hogy a könyvtár bármit digitalizálhat?

\section{[D] Ajánlott irodalom}

1404/2017. (VI. 28.) Korm. határozat a Digitális Nemzet Fejlesztési Program megvalósítása során elkészült Közgyűjteményi Digitalizálási Stratégiáról. Forrás: https://net.jogtar.hu/jogszabaly?docid=A17H1404. KOR\&txtreferer $=00000001$.txt

BÓDOG András: Könyvtárak a koronavírus-járvány idején - Pandémia és infodémia. = Könyvtári Figyelö, 30. évf. 3. sz. 2020. 419-436. p. Forrás: https://epa.oszk.hu/00100/00143/00362/pdf/EPA00143_konyvtari_ figyelo_2020_03_419-436.pdf] 
BOGNÁR Noémi Erika - HORVÁTH Adrienn - TÓTH Máté: Könyvtári digitalizálási helyzetkép. = Könyvtári Figyelö, 60. évf. 1. sz. 2018. 6173. p. Forrás: http://ki2.oszk.hu/kf/2018/04/konyvtari-digitalizalasihelyzetkep/

A digitalizálási munkálatok összehangolása - Lundi alapelvek. Fordította: Hegyközi Ilona. Forrás: http://www.mek.oszk.hu/minerva/html/dok/ lundalap.htm

DANCS Szabolcs: A hiteles digitális másolatról és a másolati példányok bibliográfiai kezeléséről - 1. rész: Hitelesség szabványos alapokon. = Könyv, Könyvtár, Könyvtáros, 26. évf. 10. sz. 2017. 7-15. p. Forrás: http://epa.oszk.hu/01300/01367/00295/pdf/EPA01367_3K_2017_10_ 007-015.pdf

PÉTERFALVI Attila [et al.] (szerk.): Magyarázat a GDPR-ról. Budapest, Wolters Kluwer, 2018. 424 p.

RADÓ Rita: A norvég csoda nyomában - avagy hogyan jött létre az első elektronikus nemzeti könyvtár Európában. = Könyvtári Figyelő, 62. évf. 3. sz. 2000. 501-506. p. Forrás: http://ki2.oszk.hu/kf/2020/10/anorveg-csoda-nyomaban-\%e2\%80\%93-avagy-hogyan-jott-letre-azelso-elektronikus-nemzeti-konyvtar-europaban/

TÓSZEGI Zsuzsanna: Az Európai Unió általános adatvédelmi rendelete, a GDPR. 1. rész: Alapfogalmak, alapelvek. = Könyvtári Figyelö, 61. évf. 1. sz. 2019. 9-35. p. Forrás: https://epa.oszk.hu/00100/00143/00355/ pdf/EPA00143_konyvtari_figyelo_2019_01_009-035.pdf

TÓSZEGI Zsuzsanna: Az Európai Unió általános adatvédelmi rendelete, a GDPR. 2. rész: A könyvtárak adatkezelöi szerepköre. = Könyvtári Figyelö, 61. évf. 2. sz. 2019. 195-210. p. Forrás: https://epa.oszk. $\mathrm{hu} / 00100 / 00143 / 00356 / p d f / E P A 00143$ _konyvtari_figyelo_2019_ 02_195-210.pdf 


\section{ESETTANULMÁNY}

\section{Előzmények és a projekt célja}

„Kultúránk egyetlen területe sem újulhat meg, fejlődhet korszerü keretek között múltja tudományos igényü rendszerezése, öröksége feldolgozása, illetve a 21. századi müködéséhez szükséges elektronikus tartalomszolgáltatási rendszerek, adatbázisok nélkül" - emelte ki Fekete Péter miniszteri biztos, a Magyar Cirkusz és Varieté Nonprofit Kft. (MACIVA) igazgatója azon a projektindító tájékoztatón, amelyet az Eötvös Loránd Tudományegyetem Bölcsészettudományi Kar (ELTE BTK) Könyvtár- és Információtudományi Intézetével (KITI) tervezett szakmai együttmüködés első közös rendezvényeként, az ELTE BTK Kari Tanácstermében tartottak 2015. szeptember 28-án (3. ábra). Kifejtette, hogy cirkuszművészetünk múltja, a vándorcirkuszi hagyományok mellett térségünk egyetlen - a Városliget történetéhez is kötődő - épített cirkuszával szinte feltáratlan, miközben élő és fejlődő jelennel büszkélkedhet a klasszikus és modern, valamint az alternatív cirkuszi kísérletek területén egyaránt. A Kari Tanácsterem falai között szokatlan élményként egy artista növendék mutatványa illusztrálta a cirkuszi produkciók évszázadok óta változatlan hatását (4. ábra). Hangsúlyozta, hogy a témában elmélyülésre motiválhatják a könyvtáros és más szakos hallgatókat a projekt által kínált hosszú távú lehetőségek, hiszen a tervezett információs központban munkatársakra is szükség lesz. ${ }^{83}$

${ }^{83}$ Könyvtár- és információtudomány a porondon. ELTE. 2015. 10. 13. Forrás: https:// www.elte.hu/content/konyvtar-es-informaciotudomany-a-porondon.t.6162 


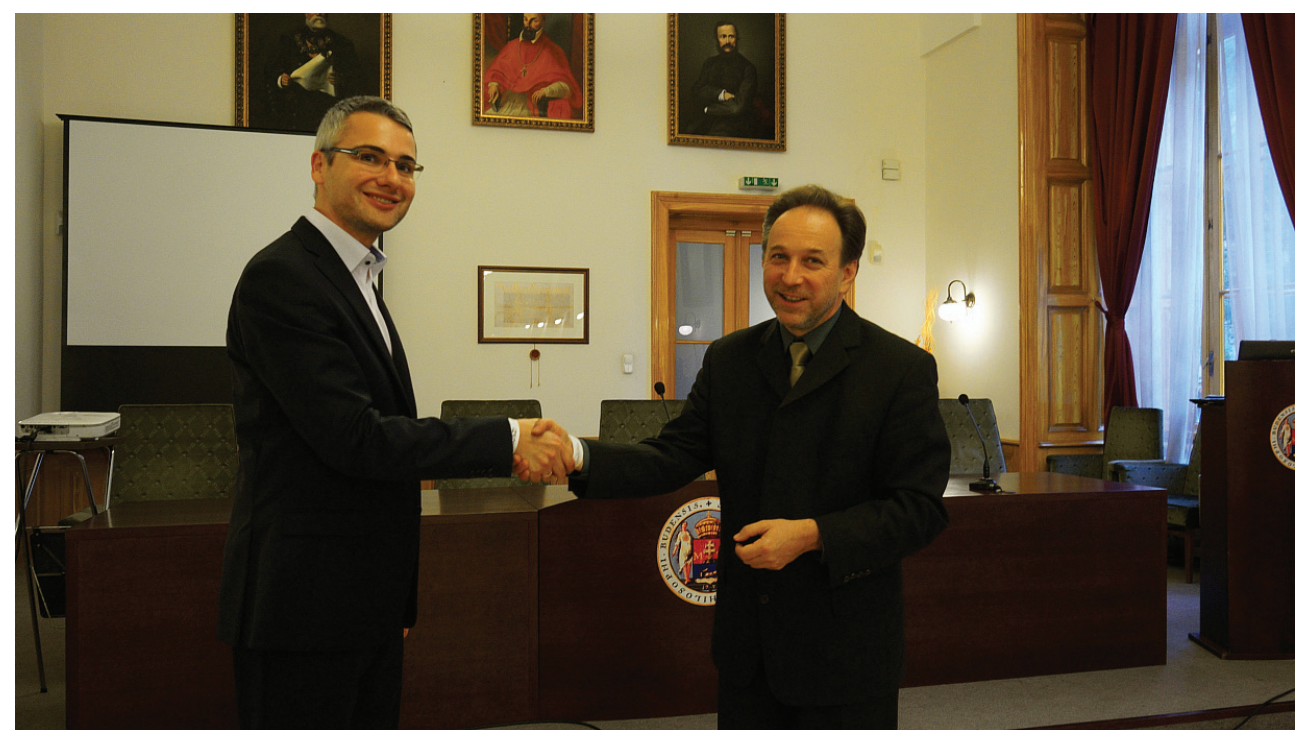

3. ábra: Fekete Péter és Kiszl Péter a 2015. szeptember 28-án tartott projektinditó tájékoztatón (Forrás: http://elte-lis.blogspot.com/2015/10/BTK-KITI-MACIVA.html)

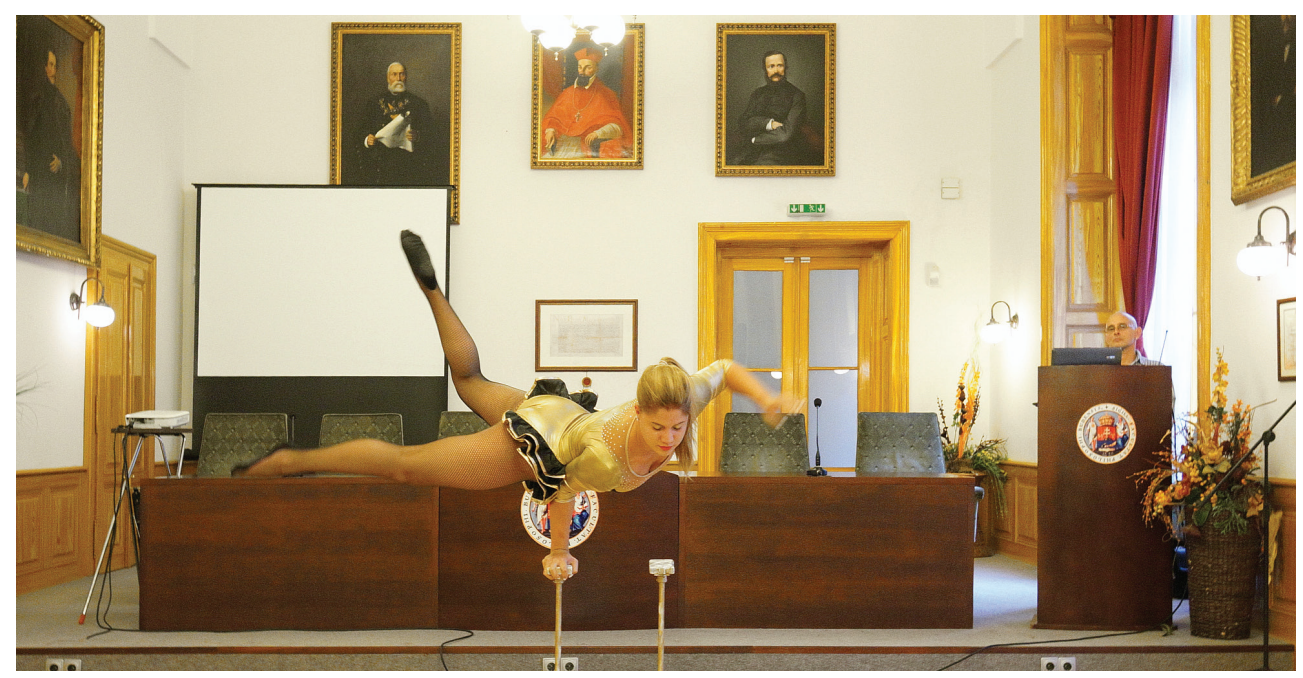

4. ábra: Artista növendék az ELTE BTK kari tanácstermében 2015. szeptember 28-án tartott projektindító tájékoztatón (Forrás: http://elte-lis.blogspot.com/2015/10/BTKKITI-MACIVA.html)

A kooperáció előkészítéseként 2015. november 28-án az együttmüködésben érintett oktatók, hallgatók és meghívott szakértők a Fövárosi Nagycirkuszban 
megtekintették a Balance címü előadást, majd Fekete Péter igazgató és Kiszl Péter intézetigazgató, valamint Barátné Hajdu Ágnes tanszékvezető irányításával szakmai egyeztetés zajlott (5. ábra). Megállapodás született, hogy elsőként - doktoranduszaink bevonásával - előkészítő tanulmány készül, mely helyzetelemzést ad és alternatívákat vázol fel a megvalósításra, továbbá felméri a MACIVA Nonprofit Kft. vonatkozó dokumentumállományát. ${ }^{84}$ A megbeszélésen többek között részt vett Juhász Éva, az ELTE Irodalomtudományi Doktori Iskola Könyvtártudományi doktori programjának hallgatója is, aki a 2019. szeptember 10-én sikeresen megvédett Könyvtárgazda(g) ság: pénzügyi vonatkozású korszerü menedzsmenteljárások könyvtári alkalmazása címü doktori (PhD) disszertációjában innen eredeztethetően hangsúlyosan foglalkozott a cirkuszművészek, a társmüvészetek, a kutatók és a nagyközönség könyvtárhasználati szokásainak, valamint a létrehozandó cirkuszművészeti információs központtal kapcsolatos igényeinek feltárásával. Pilot jellegű kérdőíves és mélyinterjús kutatása a szolgáltatástervezés inspirációs szakaszában hatékonyan támogatta a fejlesztést. ${ }^{85}$

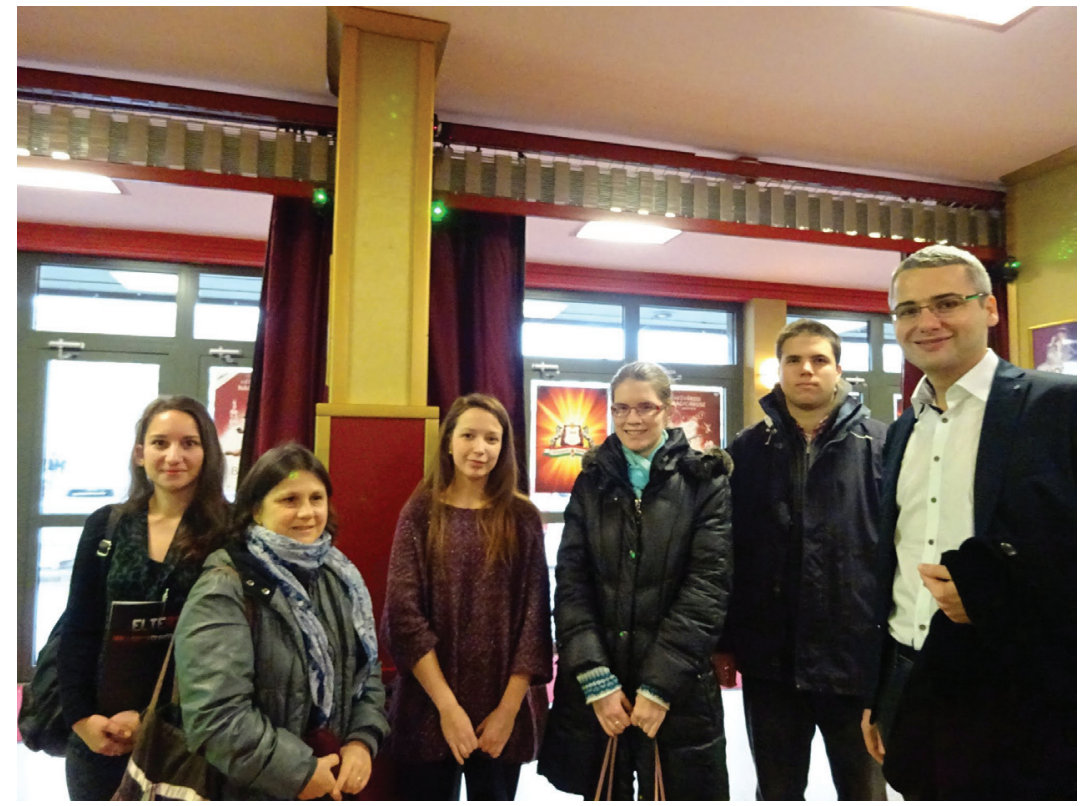

${ }^{84}$ Balance és könyvtár. ELTE LIS. 2015. 12. 14. Forrás: http://elte-lis.blogspot.com/ 2015/12/balance-es-konyvtar.html

${ }^{85}$ Meghívó Juhász Éva doktori védésére. ELTE LIS. 2019. 09. 03. Forrás: http://elte-lis. blogspot.com/2019/09/meghivo-juhasz-eva-doktori-vedesere.html 
ÚTMUTATÓ KÖNYVTÁRALAPÍTÁSHOZ

$\oplus$
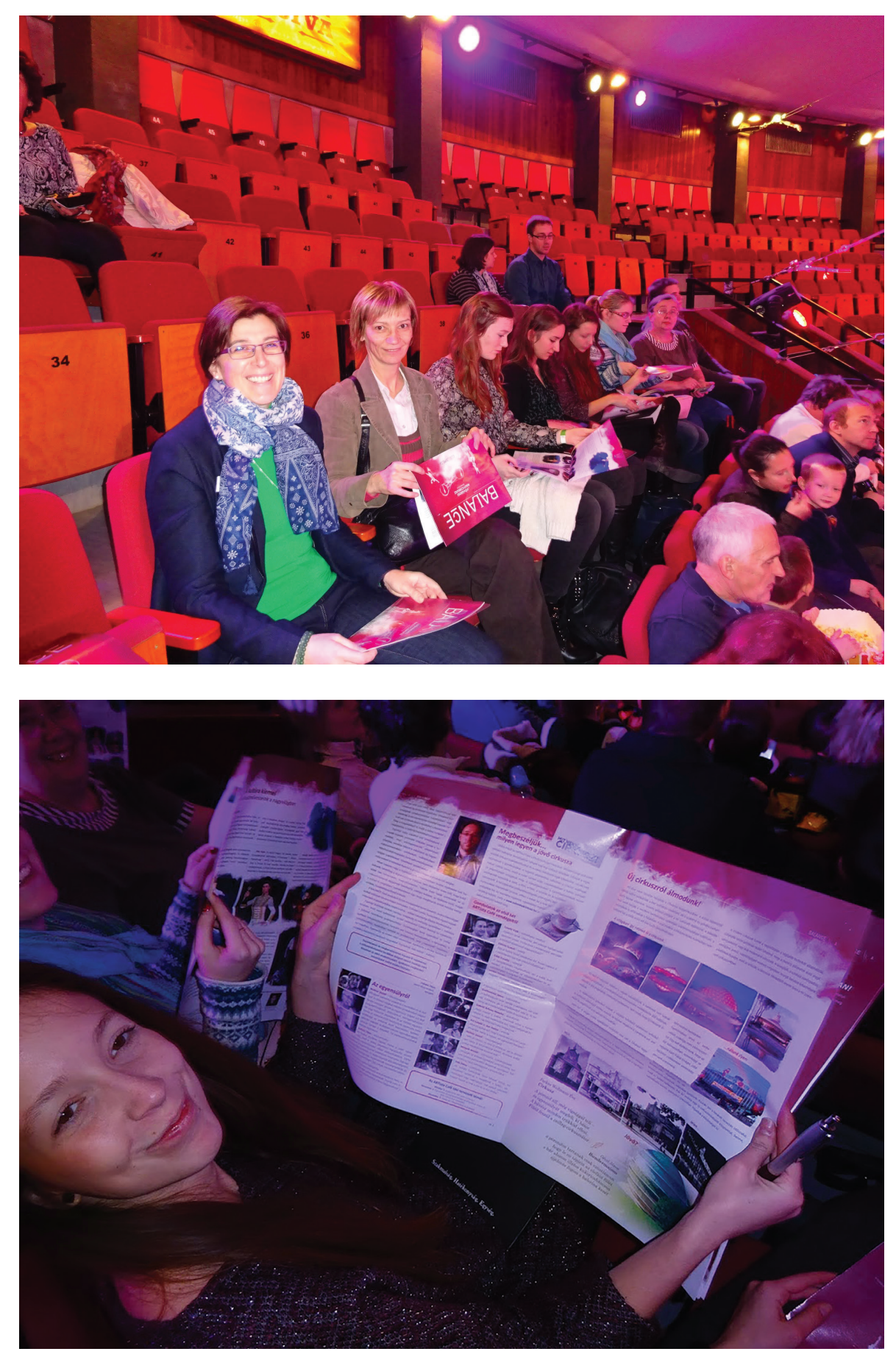

(4) 


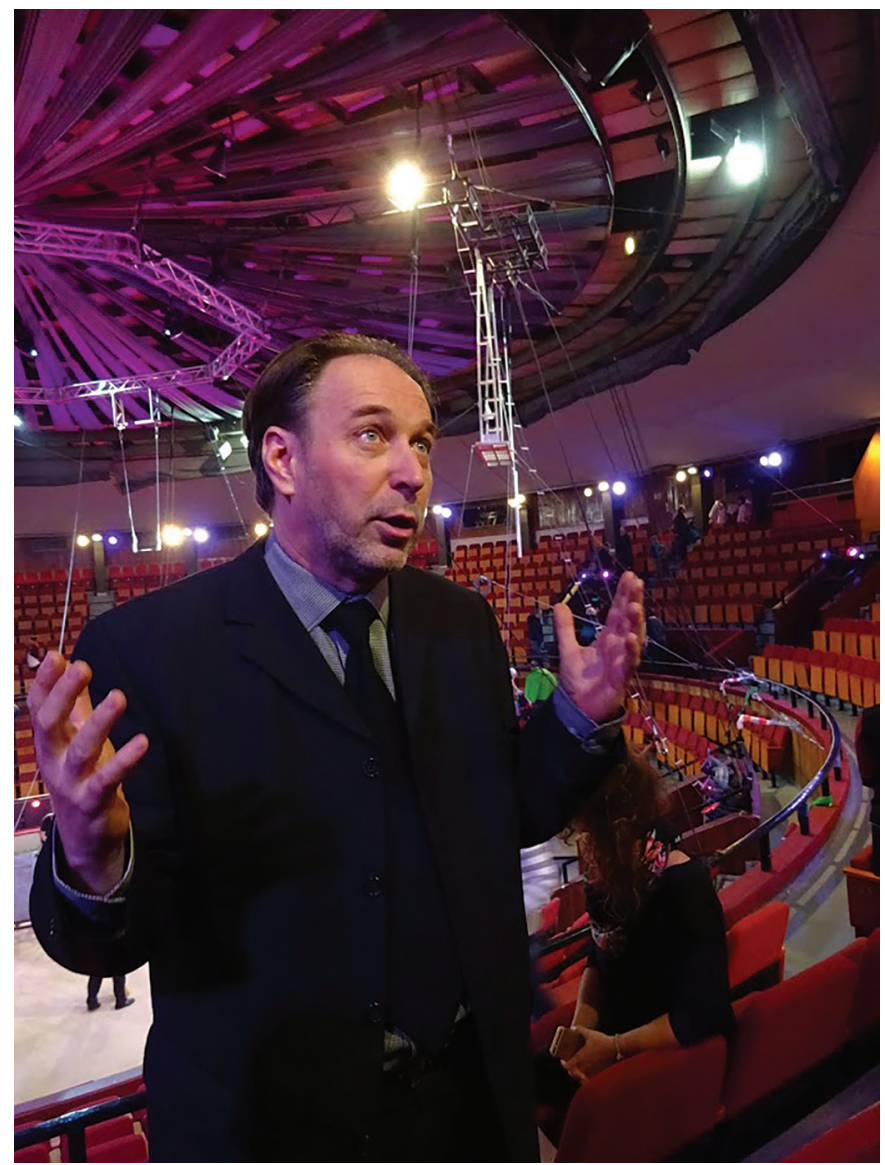

5-8. ábra: A Balance előadás megtekintése és szakmai egyeztetés 2015. november 28-án a Fövárosi Nagycirkuszban (Forrás: http://elte-lis.blogspot.com/2015/12/balance-eskonyvtar.html)

A Visegrádi Együttmüködés országainak képviselői 2019. június 11-én projektjavaslatként fogalmazták meg a cirkuszművészet megújítását, a cirkuszművészetet érintő, átfogó digitalizációt, amely ezután a V4-ek hivatalos programjának részévé válhat. ${ }^{86}$ A 2019. június 18-án kelt alapító okirat szerint megalakult a Nemzeti Artista-Előadó- és Cirkuszmüvészeti Központ Nonprofit Kft., mely számos feladata mellett létrehozza és működ-

${ }^{86}$ Communique from the 29th Meeting of the Ministers Responsible for Culture of the Visegrad Group Countries. Víglaš, June 11, 2019. Forrás:_http://www.visegradgroup.eu/ documents/official-statements/communique-from-the-29th 
teti a Magyar Cirkuszmüvészeti Múzeumot, valamint a Közép-Európai Cirkuszmüvészeti Kutatóközpontot és Adattárat. ${ }^{87}$ A Magyar Közlöny 2019. augusztus 2-i számában megjelent kormányhatározat alapján a Fővárosi Nagycirkusz összes létesítménye a Nyugati pályaudvar mellett felépülő új épületben kap majd helyet, a beruházás várhatóan jelentős távlatokat nyit a könyvtárszakmai fejlesztések előtt is. ${ }^{88}$

A 2019. szeptember 6-án létrejött szakmai együttmüködés aláírásakor (9. ábra) Fekete Péter - akkor már kulturális államtitkári pozíciójában megerősítette, hogy Budapesten fog felépülni Európa legnagyobb cirkuszművészeti központja, amely magában foglal majd egy könyvtárat, egy adattárat és egy múzeumot. A Nemzeti Cirkuszművészeti Központ várja az ELTE BTK KITI oktatóit és hallgatóit, hogy megismerjék a magyar cirkuszmüvészetet reprezentáló hagyományos és elektronikus gyüjteményt, közreműködjenek az álló- és mozgóképi dokumentumok digitalizálásában, illetve részt vegyenek a Közép-Európában egyedülálló cirkuszművészeti adatbázis építésében. A visegrádi négyek által is támogatott, a közép-európai cirkuszművészetet feldolgozó Közép-Európai Cirkuszművészeti Kutatóközpont és Adattár tehát egyszerre kívánja szolgálni a történeti megismerést, a tudományos kutatást és a müvészeti megújulást. Az együttmüködési megállapodás alapján - immár szerződés szerint is deklaráltan az ELTE BTK KITI szakmai támogatást nyújt a központ dokumentációs és adatbázisépítő tevékenységeihez, végzi az NCK munkatársainak szakmai továbbképzését, és közremüködik a legalkalmasabb gyakornok vagy pályakezdő diplomás szakember megtalálásában. ${ }^{89}$

\footnotetext{
${ }^{87}$ Nemzeti Artista- Előadó- és Cirkuszművészeti Központ Nonprofit Korlátolt Felelősségű Társaság változásokkal egységes szerkezetbe foglalt alapító okirata. MACIVA. 2019. 06. 18. Forrás: https://nemzeticirkuszmuveszetikozpont.hu/wp-content/uploads/2020/10/ alapito-okirat.pdf

${ }^{88}$ A Kormány 1495/2019. (VIII. 2.) Korm. határozata a Nemzeti Cirkuszművészeti Központ elhelyezésével összefüggő intézkedésekről. = Magyar Közlöny, 138. sz. 2019. 57885789. p. Forrás: https://magyarkozlony.hu/dokumentumok/0e673cdbd8e437b6ee79f6d0 e0046e961d701593/letoltes

${ }^{89}$ Digitalizálják a cirkuszművészet emlékeit is. ELTE. 2019. 09. 09. Forrás: https://www. elte.hu/content/digitalizaljak-a-cirkuszmuveszet-emlekeit-is.t.19532.; Együttmüködést kötött a Nemzeti Cirkuszművészeti Központ és az Eötvös Loránd Tudományegyetem Bölcsészettudományi Kara. FNC. 2019. 09. 06. Forrás: https://www.fnc.hu/hirek/item/2250egyuttmukodest-kotott-a-nemzeti-cirkuszmuveszeti-kozpont-es-az-eotvos-lorandtudomanyegyetem-bolcseszettudomanyi-kara
} 


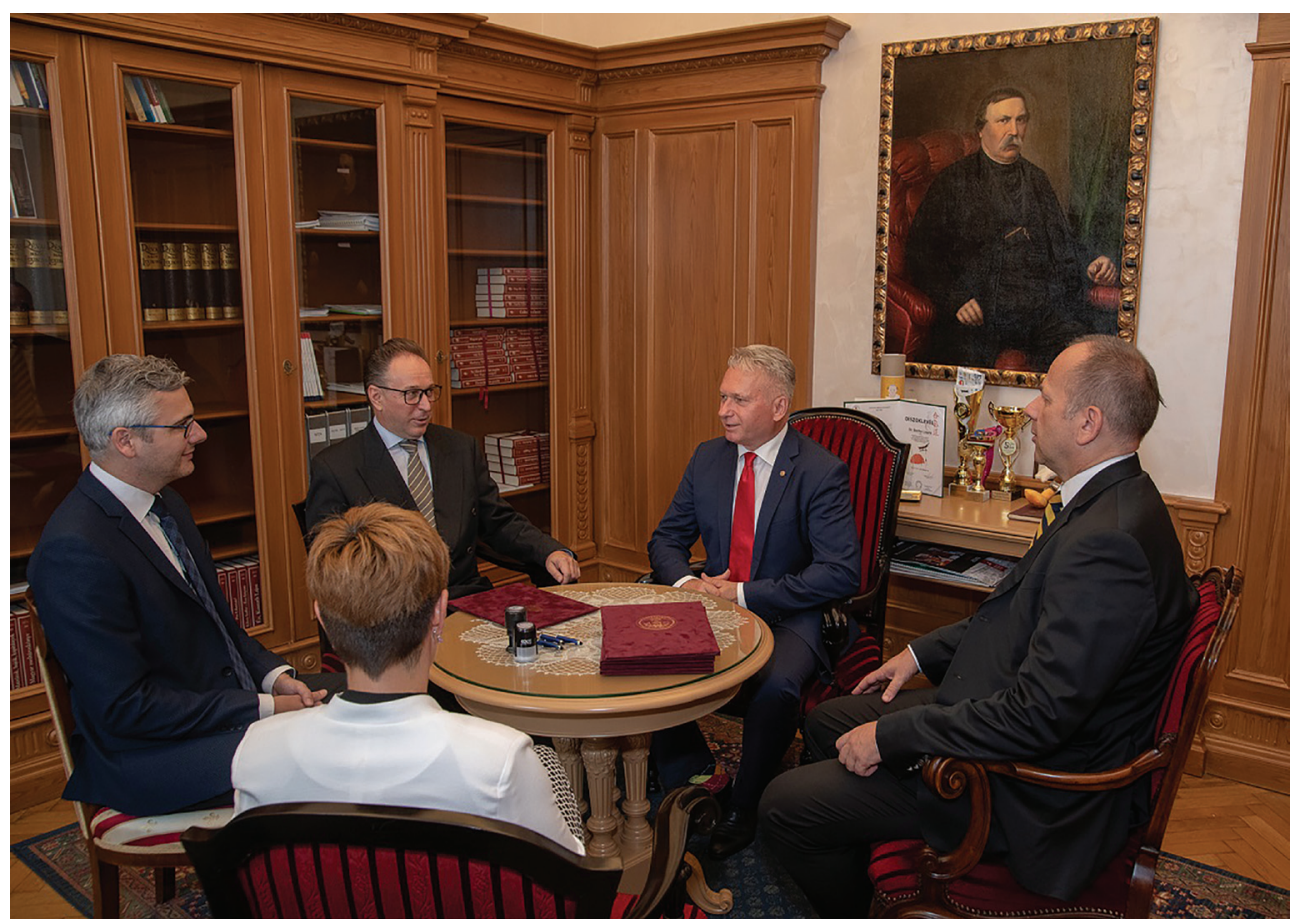

9. ábra: Szakmai együttmüködési megállapodás aláirása az ELTE rektorának irodájában 2019. szeptember 6-án (Fekete Péter, Borhy László, Sonkoly Gábor, Borsós Beáta, Kiszl Péter) (Forrás: https://fnc.hu/hirek/egyuttmukodestkotott-a-nemzeti-cirkuszmuveszeti-kozpont-es-az-eotvos-lorand-tudomanyegyetembolcseszettudomanyi-kara)

2020. január 9-én a Szépmüvészeti Múzeum Shikedanz termében, a Cirkuszi kulturális örökség címü UNESCO szakmai konferencián, ${ }^{90}$ a XIII. Budapest Cirkusz Fesztivál keretében tartott kerekasztal-beszélgetésen meghívott szakértőként részt vett Sonkoly Gábor, az ELTE BTK dékánja és Kiszl Péter (10. ábra). A rendezvényen az NCK könyvtári fejlesztéseiről Juhász Éva ELTE-alumnus, főkönyvtáros beszélt.

${ }^{90}$ Cirkuszművészeti konferencia ELTE-s kutatókkal. ELTE. 2020. 01. 13. Forrás: https:// www.elte.hu/content/cirkuszmuveszeti-konferencia-elte-s-kutatokkal.t.20224; Cirkuszi kulturális örökség - UNESCO szakmai konferencia. FNC. 2020. 01. 10. Forrás: https:// www.fnc.hu/hirek/item/2369-cirkuszi-kulturalis-orokseg-unesco-szakmai-konferencia 


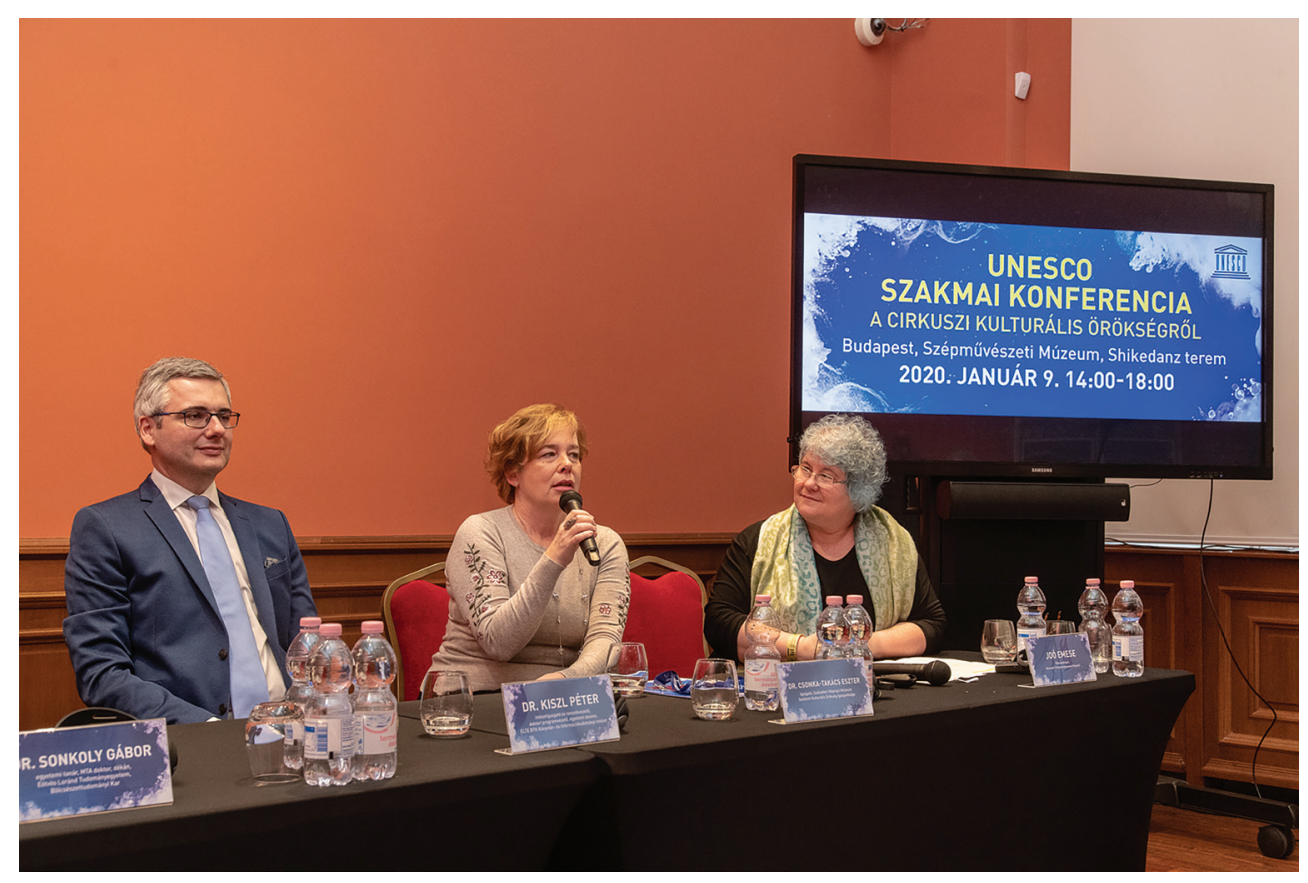

10. ábra: Cirkuszi kulturális örökség UNESCO szakmai konferencia a Szépmüvészeti Múzeumban 2020. január 9-én (kerekasztal-beszélgetés: Kiszl Péter,

Csonka-Takács Eszter, Joó Emese) (Forrás: http://elte-lis.blogspot.com/2020/01/ unesco-szakmai-konferencia-cirkuszi.html)

\section{A Nemzeti Cirkuszmủvészeti Központ a könyvtári porondon}

Az NCK az alapító okirat szerint fenntartja a Baross Imre Artistaképző Intézet Elöadó-müvészeti Szakgimnázium Gimnázium és Alapfokú Táncmüvészeti Iskolát (BIAK), és amint korábban már említettük, létrehozza és fenntartja a Közép-Európai Cirkuszművészeti Kutatóközpont és Adattár mellett a Magyar Cirkuszművészeti Múzeumot. A központ gyüjti, rendszerezi és bemutatja a cirkuszművészet tárgyi emlékeit, írásos (11. ábra), képi és mozgóképes dokumentumait (12. ábra), közgyűjteményi tevékenységet végez, tudományos kutatóintézetet müködtet. ${ }^{91}$

\footnotetext{
${ }^{91}$ A Nemzeti Cirkuszművészeti Központ Nonprofit Kft. alapító okirata. Forrás: https:// nemzeticirkuszmuveszetikozpont.hu/wp-content/uploads/2020/10/alapito-okirat.pdf
} 

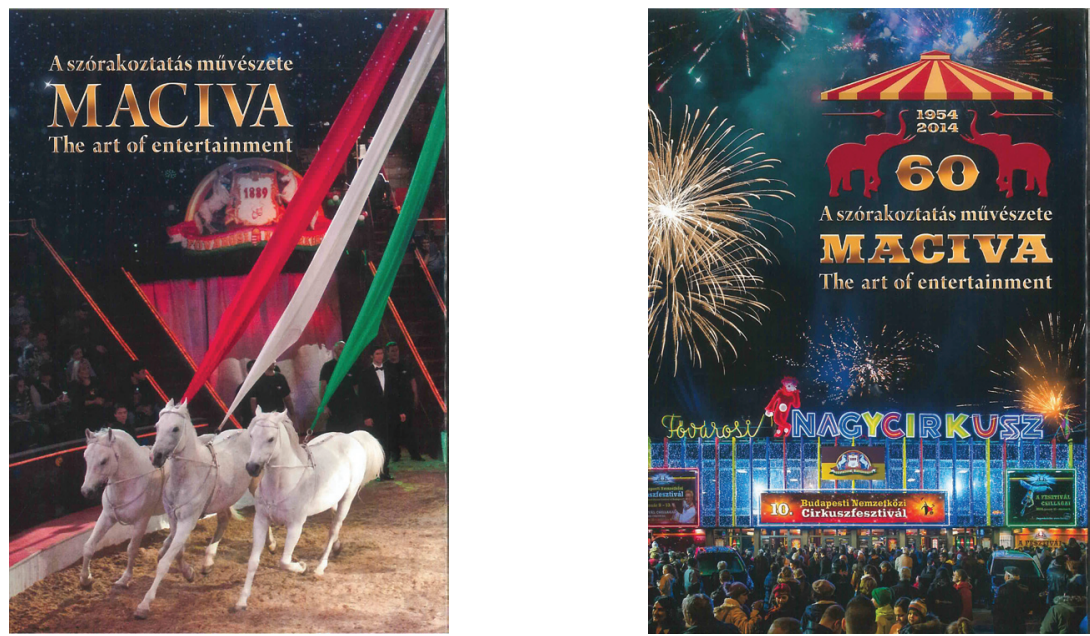

11. ábra: Maciva: a szórakoztatás müvészete. A Magyar Cirkusz és Varieté Nonprofit Kft. 2013-as és 2014-es kiadványa

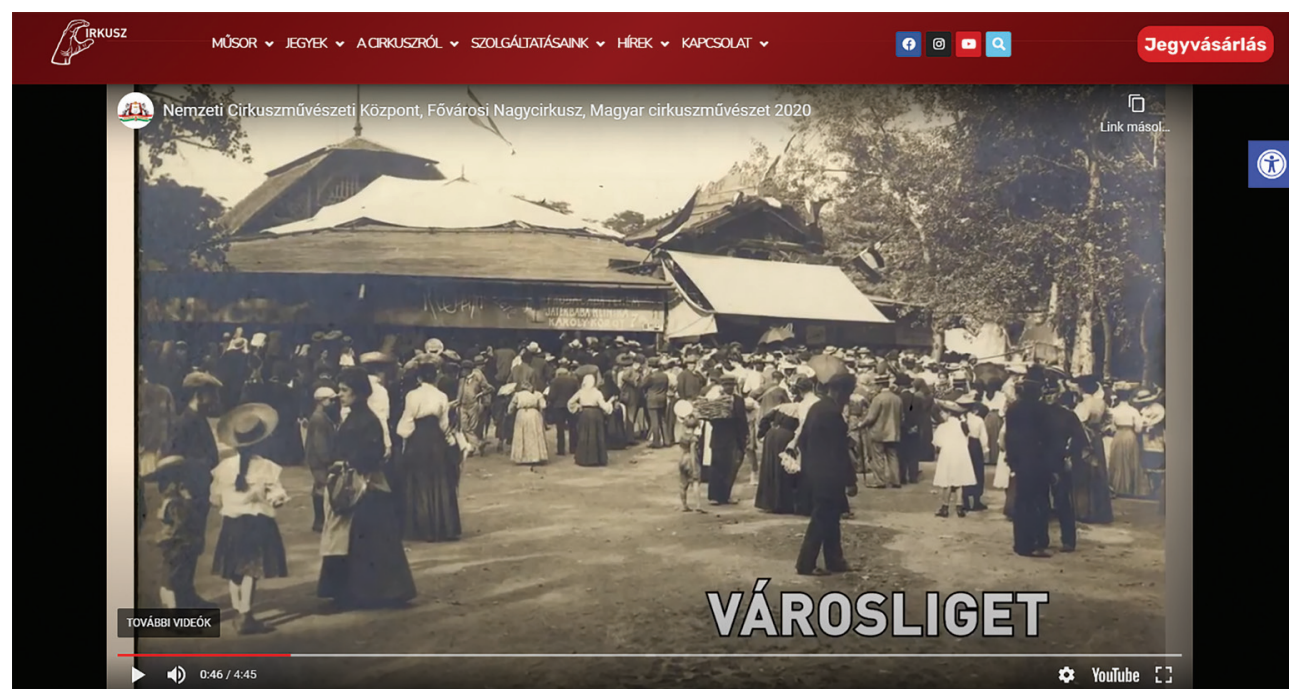

12. ábra: Részlet a Fővárosi Nagycirkusz történetét bemutató filmböl (Forrás: https://fnc.hu/tortenetunk-2-2)

Az NCK alapító okiratában és szervezeti felépítésében (13. ábra) is megjelenik a könyvtár, amely alapdokumentumainak véglegesítésére még nem került sor, így az alábbiakban néhány olyan szempontra hívjuk fel a figyelmet, amelyet mindenképp megfontolásra javaslunk. 


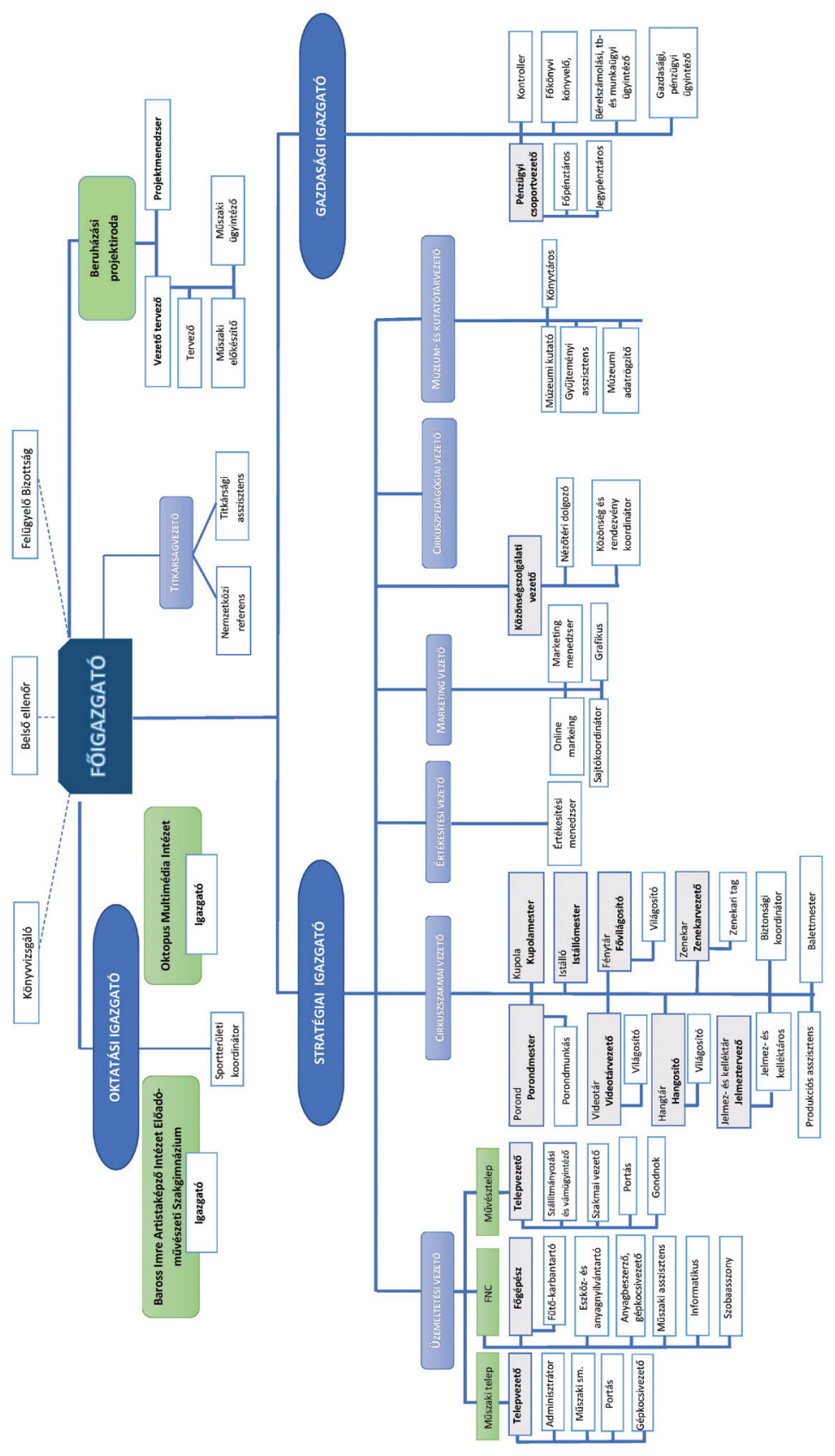

13. ábra: A Nemzeti Artista- Elöadó- és Cirkuszmüvészeti Központ Nonprofit Kft. szervezeti felépitése (Forrás: https://nemzeticirkuszmuveszetikozpont.hu/wp-content/ uploads/2020/10/2020.-vi-zleti-terv.pdf) 
Az első eldöntendő kérdések a tervezett könyvtár típusára, feladatkörére, funkciójára, jellegére, valamint a könyvtári rendszerben elfoglalt helyére vonatkoznak. Az alapító szándékának megfelelően funkcióját tekintve szakkönyvtári szerepet tölt be, amely önálló szervezeti egységként müködik a Közép-Európai Cirkuszművészeti Kutatóközpont és Adattár részeként. A hosszabb távú elképzelések között szerepel az iskolai könyvtári feladatok ellátása, elsősorban a BIAK, a Baross Imre iskola ${ }^{92}$ számára. Az iskolai könyvtári funkció kialakításáig érdemes a könyvtár és az iskola közötti együttműködési lehetőségeket áttekinteni, hiszen ez utóbbi diákjai és tanárai potenciális olvasóként jelenhetnek meg az NCK könyvtárában.

Az első fejezetben már idéztük a kulturális törvény által a nyilvános könyvtárakkal szemben támasztott alapkövetelményeket, melyek közül felidézzük a legfontosabb kritériumokat, amelyeknek az NCK könyvtárának is eleget kell tennie, amennyiben nyilvános könyvtárként fog müködni: „54. \$ (1) A nyilvános könyvtár alapkövetelményei:

a) mindenki által használható és - e törvény eltérő rendelkezése hiányában - megközelíthetö;

b) rendelkezik kizárólagosan a könyvtári szolgáltatások céljaira alkalmas helyiséggel;

c) rendszeresen, a felhasználók többsége számára megfelelő időpontban, ötezer fö feletti településen működő települési könyvtár esetében legalább heti 25 órában, továbbá legalább havonta két hétvégi napon tart nyitva;

d) vezetője a könyvtárakban foglalkoztatottak képesítési követelményeire és jogviszonyára irányadó jogszabályokban meghatározott végzettséggel és szakképzettséggel rendelkezik;

e) könyvtári szakembert alkalmaz;

f) helyben nyújtott alapszolgáltatásai ingyenesek;

g) statisztikai adatokat szolgáltat;

h) éves szakmai munkaterv alapján ellátja az $55 . \mathbb{S}(1)$ bekezdésében felsorolt alapfeladatokat, tevékenységéről éves szakmai beszámolót készít;

i) részt vesz a kulturális alapellátás kiterjesztésében;

j) elnevezésében megjelenik a könyvtár kifejezés."93

${ }_{92} \mathrm{Az}$ Artistaképző Intézet Szakgimnázium adatai a Közoktatási Információs Rendszerben. Forrás: https://www.oktatas.hu/hivatali_ugyek/kir_intezmenykereso/!KIR_ Intezmenykereso/Intezmeny/Index/201021; Az iskola honlapja. Forrás: https:/circuschool.hu

${ }^{93}$ 1997. évi CXL. törvény 
Amennyiben tehát az NCK könyvtára nyilvános könyvtárként kíván müködni, a fenti szempontokat figyelembe kell venni. Az épület tervezésénél tekintettel kell lenni az akadálymentesítésre, a tervezett állomány nagyságára és összetételére, a könyvtári szolgáltatásokra, valamint a vagyonvédelmi szempontokra.

A következő alfejezetben foglalkozunk a gyűjtőkörbe tartozó dokumentumok körével, de már itt megjegyezzük, hogy az archiválási szándék miatt a fizikai hordozón hozzáférhető dokumentumok számára a szabadpolcok mellett raktári terek, vagy legalábbis zárható tárolók kialakítása is megfontolandó. Az intézmény sajátosságai miatt audiovizuális dokumentumok is szerepelnek a gyüjtőkörben, ezekhez lejátszó eszközök beszerzése, illetve ezek használatára alkalmas tér is szükséges.

Az online tartalmak eléréséhez számítógépeket, illetve megfelelő jelerősségủ internethálózatot, valamint elektromos hálózatot, mégpedig minél nagyobb számú konnektorral kell biztosítani. A felhasználók gyakran saját laptopjaikkal, mobil eszközeikkel érkeznek a könyvtárakba, így szükségük lehet ezekhez az eszközökhöz helyre és töltési lehetőségre. Fontos felhívni a figyelmet arra, hogy 2014. szeptember 1-től a kiskorúak védelmével kapcsolatban az 1997. évi CXL. tv. 55. S. (1a) pontja kimondja:

„A nyilvános könyvtár az általa üzemeltetett, kiskorúak által is használható, internet-hozzáféréssel rendelkező számítógépek használatát a kiskorúak védelmét lehetővé tevő, könnyen telepíthető és használható, magyar nyelvű szoftverrel ellátva biztosítja a kiskorúak lelki, testi és értelmi fejlődésének védelme érdekében."

A kulturális törvény is elrendeli könyvtári szakember alkalmazását a nyilvános könyvtárakban, a létesítendő könyvtár folyamatos működtetéséhez, illetve valamennyi munkafolyamatának ellátásához azonban szükséges több könyvtárost foglalkoztatni. Az ellátandó feladatok:

- gyüjteményszervezés: a gyüjtőkörhöz kapcsolódó dokumentumok felkutatása, árajánlatkérés, cserekapcsolatok kialakítása, gondozása, megrendelés;

- feldolgozás: formai és tartalmi feltárás;

- olvasószolgálat és szaktájékoztatás;

- irodalomkutatás, témafigyelés;

- a honlappal kapcsolatos teendők (célcsoporttól függően folyamatos közösségimédia-jelenlét); 
- digitalizálás;

- elektronikus tartalmak menedzselése;

- könyvtárpedagógiai foglalkozások..$^{94}$

Az NCK honlapján elérhető 2020. évi üzleti terv a múzeumi, illetve a könyvtári fejlesztésekre 30 millió forintot irányzott elö, amely tárgyi eszközök beszerzését is előrevetítette. ${ }^{95}$ A hosszú távú együttmüködés érdekében a kooperációs lehetőségekre nyitottan a két önálló gyüjteményt célszerű külön kezelni, hogy egyértelművé váljon a kétféle szakmai feladatok tervezhetősége.

Ugyancsak az üzleti tervben olvasható - dicséretes módon - a szervezetfejlesztési szándék. A cirkuszművészeti örökség feltárásához és feldolgozásához, az állományalakításhoz szakemberekre van szükség. A cirkuszművészeti ismeretek elsajátításához létrehozandó ösztöndíjprogram kitűnő segítség a speciális szaktudás megszerzéséhez az egyéb - közgyüiteményi (könyvtár, levéltár, múzeum), pedagógiai stb. - szakterületekről érkezők számára.

A cirkusz honlapja folyamatosan megújul, aktualizálódik. A Kutatóközpont és Adattár számára érdemes rövid távon saját aloldalt kialakítani. Amennyiben a könyvtár nyilvános könyvtári szerepet fog betölteni, vagy egy önálló, vagy legalábbis könnyen megtalálható saját aloldal müködtetésére szükség lesz, és ugyanez igaz a leendő múzeum esetében is. A létrehozandó Facebook profil nemcsak a naprakész információk közlését segíti, de elősegítheti a crowdsourcing ${ }^{96}$ folyamatát, a helyismeret iránti fokozódó érdeklődés a saját képek és egyéb dokumentumok megosztására motiválhatja a felhasználókat.

A könyvtár belső tereinek és arculati elemeinek a Nemzeti Cirkuszmủvészeti Központ jövőben felépülő új székházához és annak leendő arculatához kell majd illeszkednie.

\footnotetext{
${ }^{94}$ A Fővárosi Nagycirkusz csatlakozott a Lázár Ervin Programhoz, melynek céljai közé tartozik a kritikai gondolkodás és szociális képességek fejlesztése is. Ezek a célok egybecsengenek a könyvtárpedagógiai foglalkozások céljaival is, így a Könyvtár is bekapcsolódhat a foglalkozások tervezésébe, kivitelezésébe.

${ }^{95}$ Nemzeti Cirkuszművészeti Központ Nonprofit Kft. 2020. évi üzleti terve. Forrás: https:// nemzeticirkuszmuveszetikozpont.hu/wp-content/uploads/2020/10/2020.-vi-zleti-terv.pdf ${ }^{96}$ KOSZTYÁNNÉ MÁTRAI Rita: Webarchiválás és crowdsourcing: hogyan segíthetjük a közgyüjtemények internetarchiváló tevékenységét? In: Kiszl Péter - Németh Katalin (szerk.): Információközvetítés és közösségépítés - multifunkciós könyvtári hálózatok. Budapest, ELTE BTK Könyvtár- és Információtudományi Intézet, 2020. 277-285. p. Forrás: https://doi.org/10.21862/infkoz.277
} 


\section{A Nemzeti Cirkuszmüvészeti Központ Könyvtárának állományi sajátosságai}

A központ könyvtára a jóváhagyás alatt lévő gyüjtőköri szabályzata alapján ${ }^{97}$ az alábbi célokkal végzi a dokumentumok beszerzését:

- cirkuszi előadások létrehozásához szükséges információs és inspirációs források biztosítása;

- cirkuszművészeti tanulók és hallgatók oktatásának támogatása;

- hazai és nemzetközi cirkuszmüvészeti kutatások támogatása;

- a cirkuszművészet népszerüsítése a hazai és a nemzetközi közönség körében.

A könyvtár gyüjteményfejlesztését meghatározó jogszabályok köre szintén függ a könyvtár típusától, funkciójától, valamint a beszerzendő dokumentumoktól. ${ }^{98} \mathrm{Az}$ alábbiakban a hagyományos könyvtári dokumentumokkal kapcsolatban veszünk sorra néhány lehetséges szempontot, azonban javasoljuk, hogy például a cirkuszművészethez kötődő plakátokból, brosúrákból, műsorfüzetekből legalább egy-egy példány hozzáférhető legyen a könyvtárban is. További kérdés a sajtómegjelenések és marketing anyagok gyüjtése, amelyek az NCK Marketing Osztályával együttmüködve kerülhetnének az állományba. A végleges gyűjtőköri szabályzat kialakítása előtt fel kell mérni és végig kell gondolni, hogy a könyvtári rendszerben elérhető további intézmények mely dokumentumokat szolgáltatják, kivel lehet/kell a megosztáson gondolkodni.

A fögyüjtőkörhöz tartozhatnak a patriotikumok mintájára a négy hungarikumnak megfelelö, cirkuszművészeti vonatkozású dokumentumok, különös tekintettel a saját elóállítású kiadványokra, mint például a Magyar Cirkuszmüvészeti Magazinra (14. ábra) vagy a cirkuszpedagógiai kiadványokra. ${ }^{99}$ A Közép-Európai Cirkuszművészeti Kutatóközpont és

\footnotetext{
${ }^{97}$ A fejezethez a Nemzeti Cirkuszművészeti Központ Nonprofit Kft. által rendelkezésre bocsátott gyüjtőköri szabályzat tervezete szolgált alapul.

${ }^{98}$ Például az 51/2014. (XII. 10.) EMMI rendelet a múzeum, valamint az országos szakkönyvtár és a megyei könyvtár éves munkatervéhez szükséges szakmai mutatókról. Forrás: https://net.jogtar.hu/jogszabaly?docid=a1400051.emm

99 SÁNDOR András: Munkafüzet rendhagyó tanórához. Budapest, Nemzeti Cirkuszművészeti Központ Nonprofit Kft. 13 p. Forrás: https://www.fnc.hu/images/LEP_ MUNKAFUZET_hofodtealomjavtott.pdf
} 
Adattár létrehozása azonban azt is jelenti, hogy a regionális szerep miatt meggondolandó a környező országok dokumentumainak gyüjtése.

\section{A könyvtár gyüjtőköre}

Ebben a fejezetben a gyűjtőköri szabályzatok legfontosabb pontjainak figyelembevételével összefoglaljuk a Közép-Európai Cirkuszművészeti Kutatóközpont és Adattár könyvtári gyüjteményének kialakításával kapcsolatos javaslatokat, kérdéseket. Az alábbi felsorolásba beépítettük az NCK által rendelkezésre bocsátott gyüjtőköri szabályzat tervezetében foglaltakat.

1. Dokumentumtípusok szerint

\subsection{Nyomtatott dokumentumok}

a) Könyvek

Müfajukat tekintve elsősorban a szak- és tankönyvek, referenszművek gyüjtése a könyvtár feladata.

b) Idöszaki kiadványok (periodikák)

Ebbe a körbe tartoznak

- a szabályos időközönként megjelenő időszaki kiadványok

○ szakfolyóiratok [trade journals],

○ tudományos folyóiratok [academic/scholarly/peer-reviewed journals]

- a szabálytalan időközönként megjelenő időszaki kiadványok

○ müsorfüzetek, magazinok (az előadásokhoz kapcsolódó, periodikusan megjelenő kiadványok)

\subsection{Szakdolgozatok/DLA/PhD disszertációk}

A cirkusztörténetről, cirkuszművészetről szóló magyar és idegen nyelvü kéziratok, dolgozatok nyomtatott és/vagy elektronikus formában gyüjtendők. 

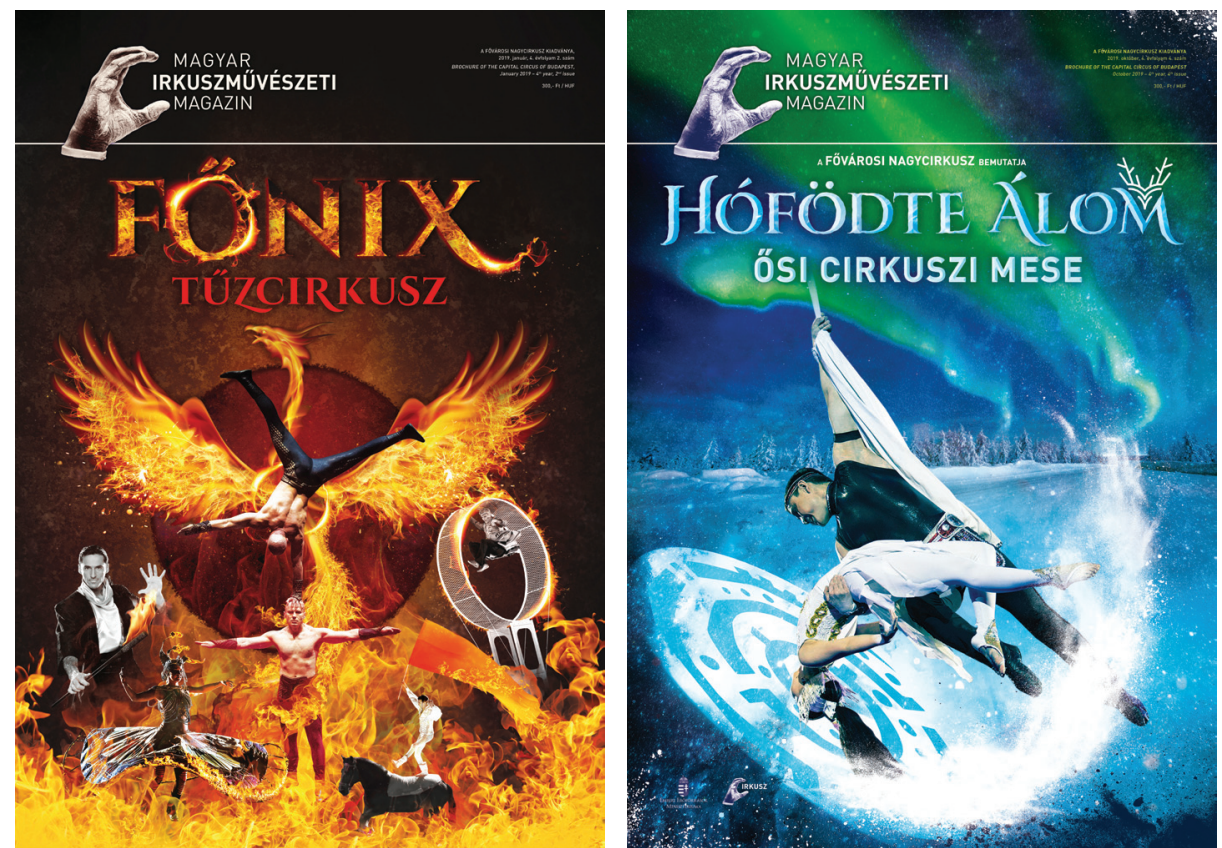

(†)

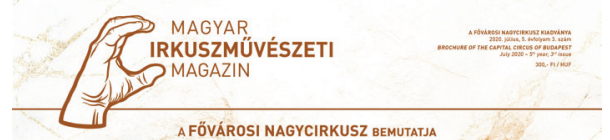

TÜNDERTÁN NC NÓVARÁTS

CIRKUSZI TÁRLATVEZETÉS
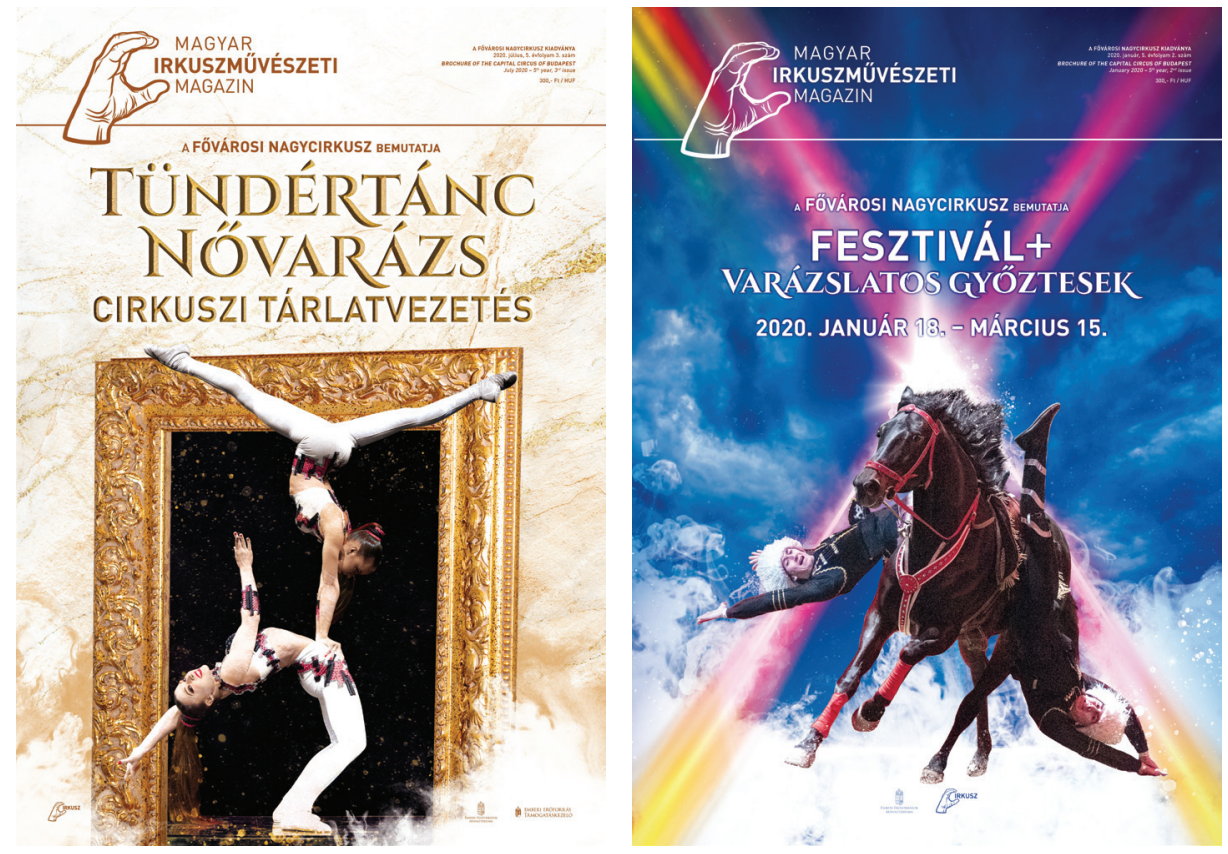

14. ábra: A Magyar Cirkuszmüvészeti Magazin 2019-2020-as számainak boritóképe (Forrás: Nemzeti Cirkuszmüvészeti Központ Nonprofit Kft.) 


\subsection{Audiovizuális dokumentumok}

Hangfelvételt és/vagy mozgóképanyagot tartalmazó dokumentumok. Az információhordozó lehet videokazetta, CD, DVD, esetleg Blu-ray lemez. ${ }^{100}$ Ajándékként, hagyatékként rendkívül értékes, unikális felvételek felajánlása várható cirkuszi előadásokról, próbákról, a szereplőkről stb. Ezen dokumentumok helye elsősorban a könyvtár, hiszen ez a szervezet lesz a lejátszásra és a külső érdeklődők fogadására alkalmas hellyel, eszközökkel ellátva.

\subsection{Digitális dokumentumok}

a) digitális (digitálisan készült / born digital) dokumentumok;

b) digitalizált (eredetileg analóg hordozóra készült, utólag digitalizált) dokumentumok.

\subsection{Tudományos/müvészeti adatbázisok:}

A mai online adatbázisok jól definiálható rendszer szerint tárolnak adatot, lehetővé téve az adatok kezelését: rögzítését, tárolását, rendszerezését, keresését, módosítását, különböző kimutatások és lekérdezések készítését. Hosszú távon a könyvtár saját adatbázist is épít, melynek részleteit a későbbiekben dolgozza ki. A szolgáltatások kezdetén már fontos lehet bizonyos szakirodalmi adatbázisok előfizetése, illetve az együttműködési lehetőségek feltérképezése a nemzetközi cirkuszművészeti intézményekkel ${ }^{101}$ az általuk kínált szolgáltatások igénybevételére.

\section{Tartalom szerint}

Összefoglalva a gyűjtőkör tartalmi aspektusait: a cirkuszművészettel és a cirkusztörténettel kapcsolatos, vagy a témát akár csak részben érintő, például az előadóművészet alapjaival foglalkozó elméleti vagy gyakorlati tárgyú, magyar nyelvü szakkönyvek, tankönyvek, ismeretterjesztő kiadványok teljes köre gyüjtendő. Emellett törekedni kell a lehető legteljesebb retrospektív állománygyarapításra - akár digitalizált másolatok gyüjtésével. Az NCK szempontjából meghatározó jelentőségű idegen nyelveken a témakörbe tartozó dokumentumok válogatva gyüjtendők.

\footnotetext{
${ }^{100}$ A videokazettákkal kapcsolatban rendkívül fontos a mielőbbi digitalizálás.

${ }^{101}$ KISZL Péter - SZÜTS Etele: Cirkuszművészeti központok tartalomszolgáltatási modelljei. = Tudományos és Műszaki Tájékoztatás, 67. évf. 3. sz. 2020. 140-160. p. Forrás: https://tmt.omikk.bme.hu/tmt/article/view/12538/14293
} 


\subsection{Fögyüjtökör}

A főgyüjtőkörbe tartoznak azok a megszerzendő dokumentumok, amelyek a könyvtár alapvető funkcióját segítik ellátni, ezért a létrejövő könyvtár fő gyüjtőköre a cirkuszművészeti, valamint az intézményben folyó oktatást, kutatást támogató információs forrásokat jelentik az alábbi témakörökhöz kapcsolódóan:

- cirkusztörténet,

- cirkuszművészeti műfajok,

- cirkuszmúvészeti technikák,

- backstage (színfalak mögötti),

- cirkuszpedagógia (15. és 16. ábra).
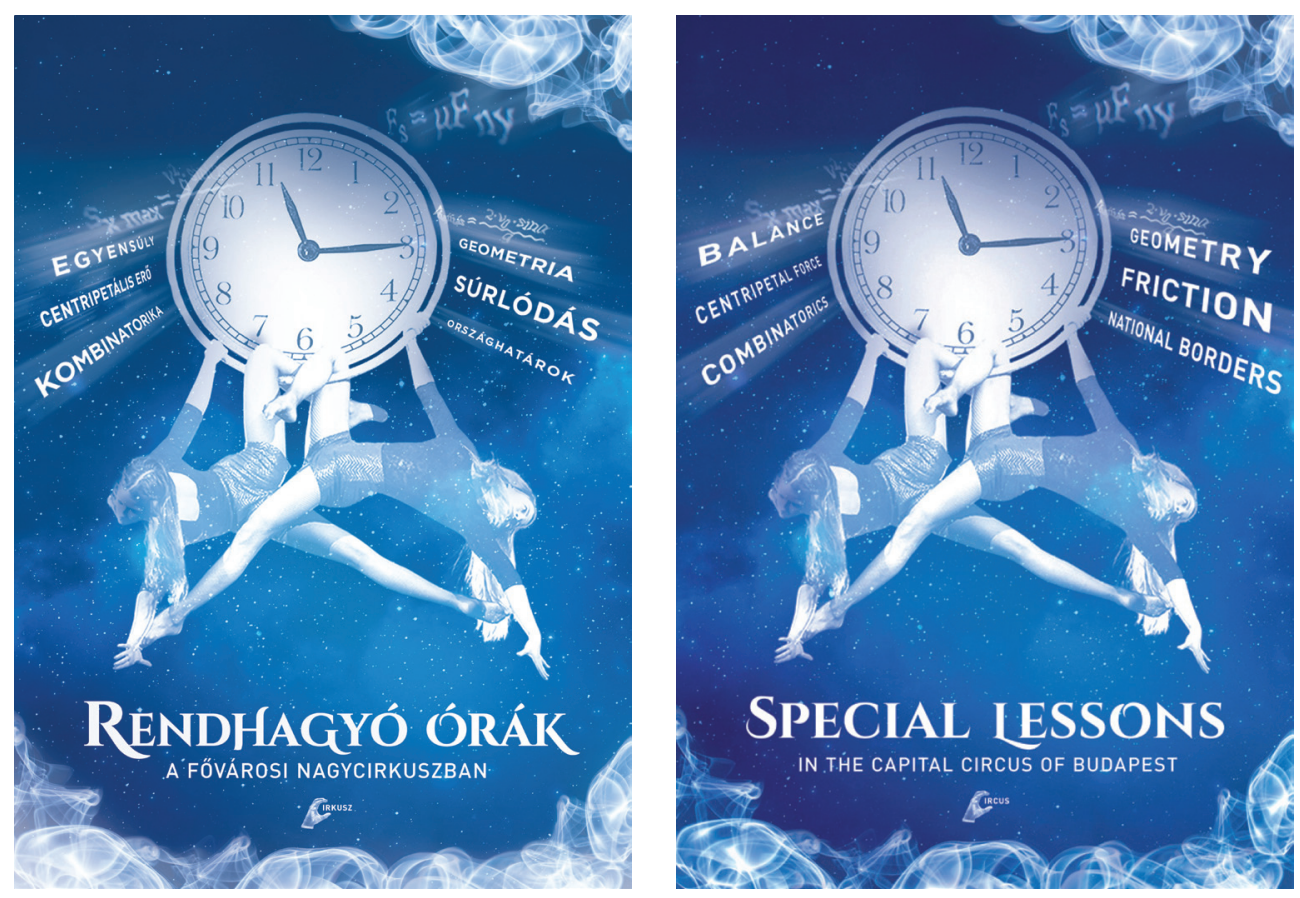

15. ábra: Cirkuszpedagógiai kiadvány boritója

(Forrás: Nemzeti Cirkuszmüvészeti Központ Nonprofit Kft.) 


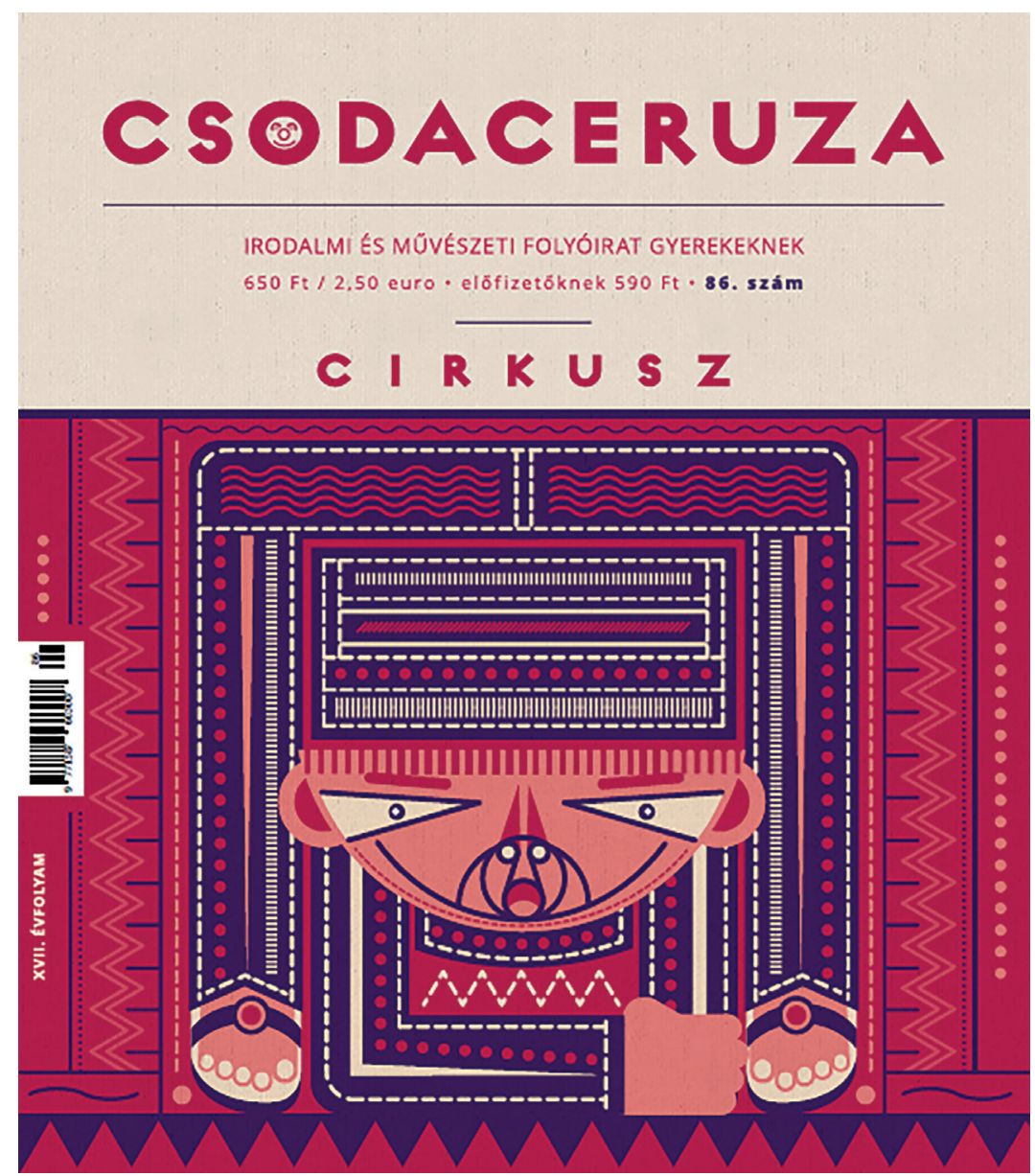

16. ábra: A Csodaceruza 2018-as cirkuszi tematikájú lapszáma (Forrás: http://csodaceruza.hu/?p=16128)

A könyvtár a majdani nyilvános és tudományos szakkönyvtári feladatának megfelelően teljességre törekedve gyűjti:

- Magyarországon, magyar nyelven megjelent;

- Magyarországon, idegen nyelven megjelent, magyar vonatkozású;

- külföldön, magyar vagy idegen nyelven megjelent, magyar vonatkozású;

- külföldön, idegen nyelven megjelent, nem magyar vonatkozású a fögyüjtőkörébe tartozó információs forrásokat. A fenti elvek figyelembevételével megfontolandó a szomszédos országok cirkuszművészeti szakirodalmának gyüjtése. 


\subsection{Mellékgyüjtökör}

A mellékgyüjtőkör a főgyüjtőkör határterületeinek információit hivatott biztosítani, tehát ezt a szempontot figyelembe véve válogatja a beszerzendő információs forrásokat. A könyvtár a majdani nyilvános és tudományos szakkönyvtári, valamint iskolai könyvtári szerepének betöltése céljából válogatva gyüjti a cirkuszmüvészeti vonatkozású

a) társművészeti dokumentumokat (színház-, film-, tánc-, zene-, képző-, fotó-, ipar- és építőművészet, szépirodalom stb.);

b) társtudományi dokumentumokat (művészetesztétika és művészettörténet, pszichológia, pedagógia, muzeológia, könyvtártudomány, jog, néprajz, szociológia, természettudományok, alkalmazott tudományok [orvostudomány, anatómia, élettan, balesetvédelem], irodalomtudomány, földrajz, történelem, régészet, művelődéstörténet, müemlékvédelem).

A felsorolásból jól érzékelhető, hogy a cirkuszi világ számos tudományterület és művészeti ág eredményeit felhasználja, akár a cirkuszépületek vagy az előadások tervezése során, akár a balesetvédelem területén. Nyilván nem lehet minden területet teljes mértékben lefedni, és ezek a források ritkán szólnak közvetlenül a cirkuszról, de egy-egy jól megválasztott dokumentum jelenléte indokolt az NCK könyvtárában. Ennél a pontnál azonban kiemelt jelentőségű az együttműködés más intézményekkel, mivel így tud költséghatékonyan, mégis széleskörűen információt szolgáltatni a létrejövő cirkuszi könyvtár.

Mind a dokumentumok tartalma, mind az információhordozó típusa meghatározza a partnerintézmények (például Semmelweis Egyetem Központi Könyvtár, OSZK Szinháztörténeti Tár, Nemzeti Audiovizuális Archivum stb.) körét.

A cirkuszmúvészethez hozzátartozik az előadások zenei anyagának előkészítése, komponálása, így a közvetlenül a cirkuszok számára írt darabok hanganyagának, kottáinak beszerzése is indokolt. A zenetörténettel és -elmélettel kapcsolatos egyéb dokumentumot számos hazai intézmény tesz elérhetővé, mint a Fövárosi Szabó Ervin Könyvtár Zenei Gyüjtemény, ${ }^{102}$ a Magyar Zenei Információs Központ, ${ }^{103}$ az Országos Idegennyelvü Könyvtár és Zenei Gyüjtemény ${ }^{104}$ stb.

${ }^{102}$ Fővárosi Szabó Ervin Könyvtár Zenei Gyűjteménye. Forrás: http://www.fszek.hu/ konyvtaraink/kozponti_konyvtar/zenei_gyujtemeny

${ }^{103}$ BMC Könyvtár. Forrás: https://info.bmc.hu/zenei-konyvtar

${ }^{104}$ Országos Idegennyelvű Könyvtár és Zenei Gyüjtemény. Forrás: https://www.oik.hu 


\subsection{Kiegészitö gyüjtökör}

Ide tartoznak a fent nem említett, de az NCK egésze szempontjából fontos dokumentumok, mint például

- az általános tájékoztatás információs forrásai (napi- és hetilapok, folyóiratok stb.);

- a BIAK tantárgyaihoz kapcsolódó dokumentumok (tankönyvek, kötelező olvasmányok, továbbá szótárak, lexikonok, enciklopédiák);

- az intézmény müködését segítő gazdálkodási, igazgatási, jogi stb. tárgyú szakanyagok.

3. Nyelv szerinti felosztás

a) A cirkuszművészettel közvetlen kapcsolatban álló, magyar nyelven megjelenő dokumentumok teljességre törekvően.

b) Idegen nyelvű dokumentumok válogatva (17. ábra).

c) A latintól eltérő írásjelü dokumentumok gyüjtése abban az esetben indokolt, ha

- a nyelvet ismerő felhasználók körében kereslet mutatkozik rá;

- a dokumentum a képi anyagának köszönhetően nyelvi ismeretek nélkül is informatív (például túlnyomórészt fotókat tartalmazó dokumentum);

- a dokumentum magyar és/vagy angol nyelvre lefordított változata rendelkezésre áll;

- a dokumentum tartalmaz magyar és/vagy angol nyelvü fordítást.

A b) és c) pont esetében, mivel az intézmény Közép-Európa számára szolgáltat információt, megfontolandó a környező országok nyelveinek felsorolása az elsődleges angol mellett. A szomszédos országok írásrendszereit figyelembe véve, indokolt lehet cirill betüs szakirodalom gyűjtése is. Ajándékként egyéb nyelvü dokumentum is elfogadható, azonban azt pontosítani kell, hogy vásárlás útján mely idegen nyelven megjelent dokumentumokat szükséges beszerezni.

\section{Megjelenési idő}

Más művészeti ágakhoz hasonlóan a cirkuszművészeti információ sem évül el, ezért a megjelenési idő meghatározása az egyes dokumentumok beszerezhetőségét, hozzáférhetőségét veszi figyelembe. 

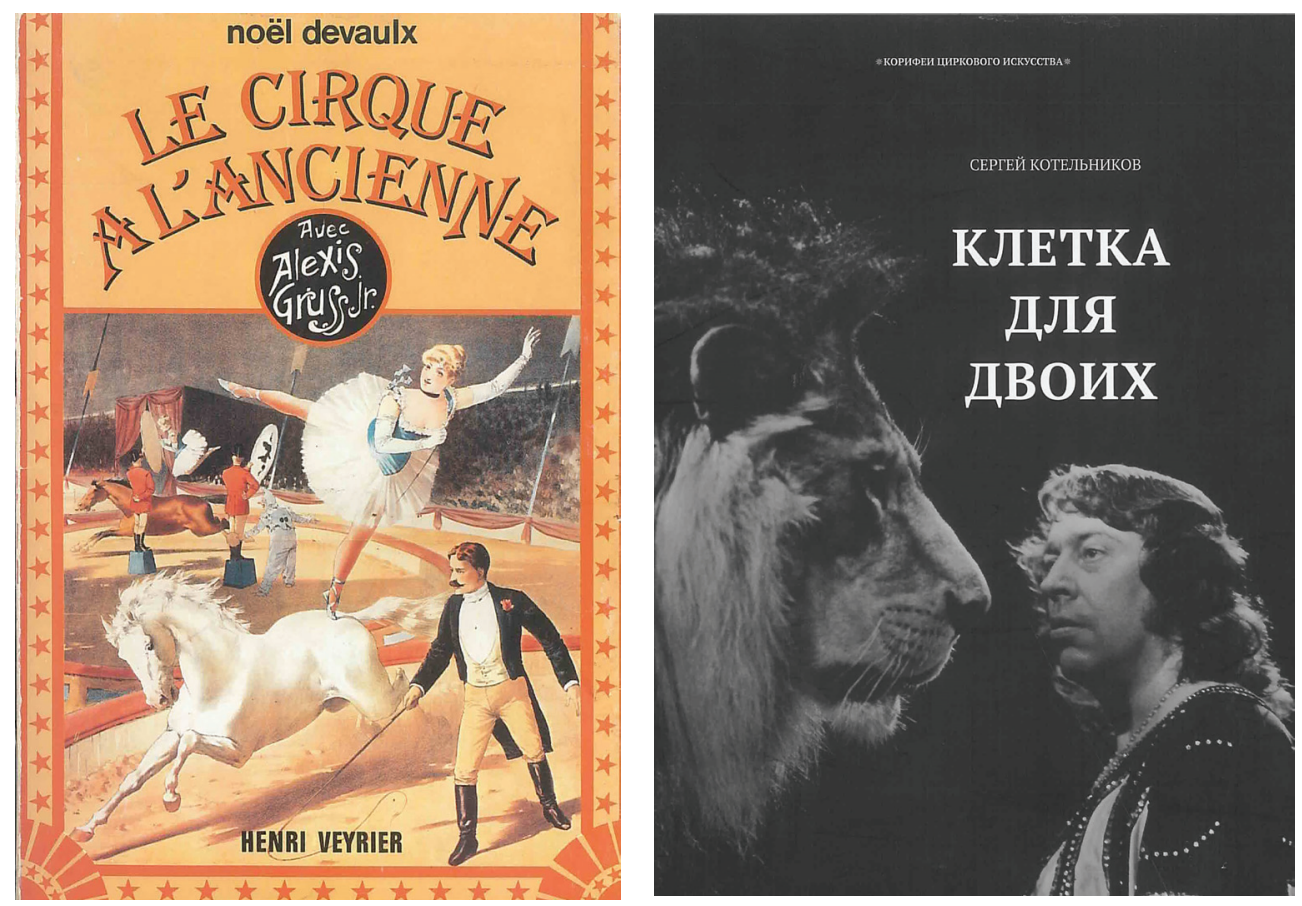

17. ábra: Idegennyelvü könyvek az NCK könyvtárának gyüjteményében

(Forrás: Nemzeti Cirkuszmüvészeti Központ Nonprofit Kft.)

A főgyűjtőkörben megjelölt dokumentumok folyamatos retrospektív gyarapítása javasolt, mivel azokat teljességre törekedve gyüjti a könyvtár. A mellék- és kiegészítő gyűjtőkörhöz tartozó dokumentumok az együttmüködő partnerintézmények állományának ismeretében válogatva, húsz évre visszamenően gyüjtendők.

Tudományos és szakmai folyóiratok: a folyóirat előfizetésének évétől gyüjtendők. Az NCK könyvtárának szakkönyvtári szerepe miatt retrospektív gyarapítás részeként korábbi számok gyüjtése is indokolt, ettől azonban el lehet tekinteni, amennyiben hosszú távon biztosított az (online) hozzáférés a kérdéses dokumentumokhoz.

\section{Példányszám}

A beszerzendő dokumentumok példányszámának meghatározásakor figyelembe kell venni az adott dokumentum iránti várható igényt, a dokumentum árát, beszerezhetőségét, az együttmüködési lehetőségeket. 
A gyüjtőköri szabályzat véglegesítése előtt fontos a könyvtár és a múzeum közötti egyeztetés, a feladatok összehangolása, az átfedések, párhuzamosságok elkerülése. Néhány dokumentumtípus esetében előfordulhat, hogy szigorúan véve egyikük állományába sem illeszkedik szervesen, de egy-egy példányt a másik tagintézmény is őrizhet. Hasonló gyűjtőköri egyeztetést és együttműködést kell kialakítani a BIAK-kal a határterületi tankönyvek és az oktatáshoz szükséges egyéb irodalom terén.

A könyvtári gyüjtemény értékét a tervszerü, felhasználói igényeken is alapuló állományalakítás határozza meg. A gyarapítás módjai és forrásai az alábbiak lehetnek:

- vétel: hazai és külföldi terjesztőktől valamennyi dokumentumtípusra kiterjedően (kurrens és retrospektív);

- csere: belföldi és külföldi kiadványcsere kapcsolatokra építve;

- NCK saját kiadványai;

- szakdolgozatok, disszertációk;

- ajándék: a könyvtár számára térítésmentesen felajánlott dokumentumok köre;

- hagyatékok.

A hagyatékok és ajándékok esetében tisztázni kell, hogy a könyvtár mely dokumentumokat fogadja el, illetve melyeket köteles visszautasítani a gyüjtőkörnek megfelelően, továbbá meg kell határozni az elfogadott dokumentumok használatára, szolgáltatására és esetleges továbbadására vonatkozó feltételeket. Például másodpéldány elfogadható, amennyiben fokozott igény mutatkozik az adott dokumentum iránt.

Minden könyvtárnak a vonatkozó jogszabályok figyelembevételével kell döntenie arról, hogy a rendelkezésére álló dokumentumok közül melyeket őriz meg tartósan, és melyek esetében, mikor történhet meg az állományból való kivonás. Az NCK által kiadott dokumentumokat (brosúra, szórólap, évkönyv, szabályzat stb.) nem érintheti az apasztás. Az NCK könyvtárának célszerü tartósan megőriznie:

- a főgyüjtőkörébe tartozó szakterületek információs forrásait;

- az NCK intézményeihez kapcsolódó képzésekben szerepet játszó dokumentumokat;

- a tudományos kutatáshoz szükséges szakirodalmat tartalmazó dokumentumokat; 
- az általános tájékozódás/tájékoztatás dokumentumait;

- a tudományos és szakfolyóiratokat.

A fenti szempontokat össze kell hangolni a digitalizálási célokkal, melyek szintén hatást gyakorolnak a beszerzendő és megőrzendő dokumentumok körére és példányszámára, ezért a következő fejezetben a digitalizálási lehetőségekről adunk rövid összefoglalót.

\section{A Nemzeti Cirkuszmüvészeti Központ Könyvtára és a digitalizálás}

Kötetünk készültekor az NCK könyvtára alakulófélben van, digitalizálási munkálatait tekintve a tervezésnél tart, digitalizálási tevékenységének alapvető célja a dokumentumok megőrzése és a könyvtári szolgáltatás kiterjesztése.

Ismételten hangsúlyozzuk, hogy a szolgáltatás megtervezésekor mind a szerzői jogi, mind az adatkezelési kérdésekben az érvényben lévő jogi szabályozásnak megfelelően kell eljárni.

A kötet Könyvtári digitalizálás célja (62-63. p.) fejezetével összhangban az NCK könyvtár digitalizálási tevékenységének céljai között a könyvtár dokumentumállományának védelme az elsődleges szempont.

A szerzői jogi szempontból nyilvánosságra hozható digitalizált tartalmak szolgáltatásba vonásával az NCK könyvtár jelentősen növelhetné távfelhasználóinak számát, illetve elősegítené új típusú szolgáltatások bevezetését, mint például a digitális könyvtár kialakítása, vagy a hasonló gyüjtőkörrel rendelkező nemzetközi intézményekkel való együttmüködés lehetőségének a növelése, akár kölcsönös állománygyarapítási céllal. A digitális gyüjtemény létrehozásával növekedne a kutatásba bevont anyagok száma, és az esetleg kevesek számára ismert gyűjteményrészek publikálási és felhasználási lehetőségeit is bővítenék. A digitális kulturális örökségi tartalmak közzététele az oktatás mellett a cirkuszművészet népszerüsítését és a közművelődést is szolgálná. A könyvtár napi szinten tudna a BIAK képzéseihez digitális oktatási segédanyagokat és irodalmat szolgáltatni. 
A digitalizálás stratégiai elvei tekintetében ${ }^{105}$ a társadalmi igény elve alapján az NCK könyvtárában olyan gyüjteményegységek digitalizálására kerül sor, amelyek egy intenzíven kutatott területről nyújtanak átfogó képet, nemzeti és nemzetközi érdeklődésre számot tartó kulturális örökségi tartalmak, továbbá meghatározó elemei a nemzeti és helyi identitásnak. A működéshez igen fontos „elégséges adat elve” viszonylag könnyen teljesíthető, mivel az analóg állomány is a feldolgozási szakaszban tart, ezért mind az analóg dokumentumok azonosításához szükséges adatok, mind pedig a digitális szolgáltatáshoz elengedhetetlen metaadatok könnyen biztosíthatók. Az „adatmentés elve” az NCK könyvtárának esetében egyrészt a rossz állapotú vagy igen ritka dokumentumok esetében érvényes, másrészt pedig a vékony és kevésbé jó minőségủ papírra nyomtatott plakátok, szórólapok sokszori mozgatásával együtt járó állagromlást tudják ezzel csökkenteni vagy teljes mértékben megakadályozni. Az „újrahasznosítás elve” alapján a közzététel elősegíti a kreatív felhasználást, továbbá a kereskedelmi felhasználáson keresztül hozzájárulhat a kulturális gazdaság fejlesztéséhez.

A digitalizálásra szánt dokumentumok kiválasztásánál az NCK esetében elsődleges szempont az állomány védelme. Az NCK Könyvtár magyar nyelvü anyagának más gyüjteményekben való online elérhetőségére a speciális gyüjtőkör miatt viszonylag kicsi az esély, de a külföldi cirkuszművészeti irodalom hozzáférhetőségének ellenőrzése az erőforrásoptimalizálás szempontjából mindenképpen ajánlott. Mivel a könyvtár szolgáltatáspolitikája is alakulófélben van, ezért a digitális dokumentumok szolgáltatására vonatkozó döntéseket ezzel összhangban kell meghozni.

A digitalizálási munkálatok megkezdése előtt a szükséges iránymutató dokumentumok elkészítése elengedhetetlen. Az NCK Könyvtár digitalizálási stratégiájának az állománydigitalizálás céljait és az intézmény szolgáltatáspolitikájának a digitalizálási munkafolyamatokkal összehangolt stratégiai céljait az itt felsorolt elméleti megközelítések figyelembevételével kell tartalmaznia.

Az NCK Könyvtár digitalizálási szabályzatának elméleti kérdéseit érdemes minél előbb végig gondolni, a hazai és nemzetközi jó gyakorlatokat tanulmányozni, megismerni az erre vonatkozó ajánlásokat. A digitalizálási munka megtervezéséhez összeállítandó digitalizálási tervnek a már meglévő és a későbbiekben beszerzendő állomány digitalizálási ütemtervét is

${ }^{105}$ Vö. A digitalizálás stratégiai elvei (63-65. p.) című fejezettel. 
tartalmaznia kell; a konkrét időpontokat a munkálatok reális elkezdése után lehet meghatározni. A könyvtár jelenleg nem rendelkezik az állományvédelmi szempontoknak megfelelő digitalizálás elvégzéséhez szükséges berendezésekkel, így ezek az adatok később kerülnek be a tervbe. A digitalizálás területén pillanatnyilag a szükséges erőforrások előteremtése az elsődleges feladat. Amikor a könyvtár már rendelkezik a digitális könyvtár fejlesztéséhez szükséges belső vagy külső informatikai kapacitással, akkor lehet a digitalizálási szabályzatban meghatározni a digitalizálás minőségi követelményeit (pl. fájlformátum, képfelbontás), módszertanát, illetve a megőrzés technikai és minőségi kérdéseit.

Az NCK Könyvtár esetében egy digitális könyvtár kialakításának és szolgáltatásainak megtervezését párhuzamosan végezhetjük az analóg gyüjtemény létrehozatalával, lehetővé téve egy nagyon átgondolt koncepcióval rendelkező, jól strukturált, a tartalomszolgáltatói funkcióját a felhasználók igényeire építő, az NCK arculatához (18. ábra) illeszkedő szolgáltatási felülettel támogatott könyvtár megszületését.
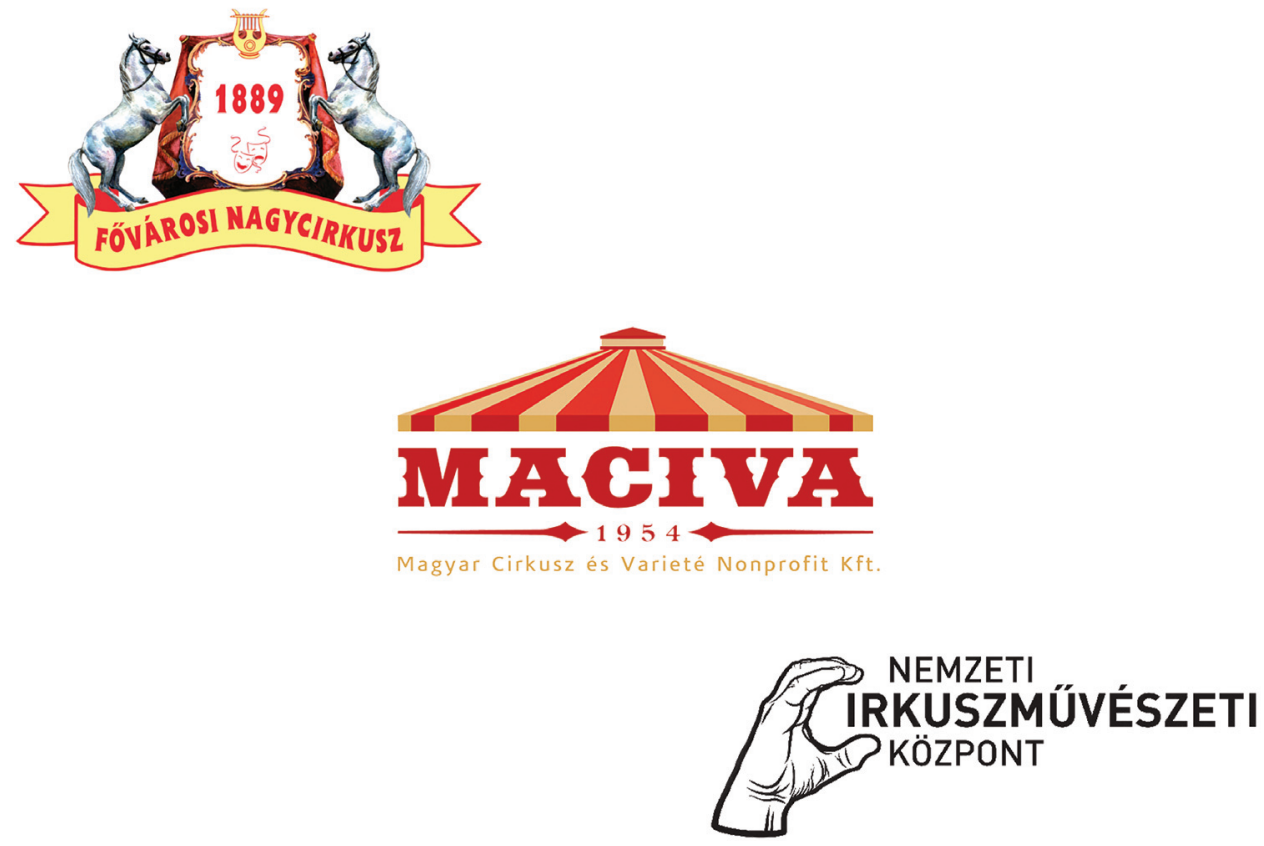

18. ábra: A Nemzeti Cirkuszmüvészeti Központ egykori és jelenlegi arculati elemei (Forrás: Nemzeti Cirkuszmüvészeti Központ Nonprofit Kft.) 


\section{ÚTMUTATÓ A SZAKMAI GYAKORLATOKHOZ}

\section{Útmutató a Nemzeti Cirkuszmüvészeti Központ Nonprofit Kft. által alapított Közép-Európai Cirkuszmüvészeti Kuta- tóközpont és Adattár Könyvtárában teljesítendő könyvtáros szakmai gyakorlatokhoz}

Az újonnan alakult intézmény összegyűjti, megőrzi és hozzáférhetővé teszi a hazai, valamint a közép-európai országok cirkuszművészetének írásos, képi és tárgyi emlékeit, valamint szakirodalmi forrásait, amelyhez a korszerü digitális technológiát is alkalmazza. Az elképzelések szerint a központ egyszerre látja el a cirkuszművészeti szakkönyvtári, az iskolai, valamint közművelődési könyvtár szerepét, ezáltal információs, egyben inspirációs forrást biztosít a művészi produkciók létrehozásához, és emellett közösségformáló szerepet is ellát. A Központ kapcsolatot tart fenn a hazai és külföldi cirkuszművészeti és társművészeti intézményekkel a tapasztalatszerzés, a forrásmegosztás, valamint a szolgáltatásbővítés céljából; rendelkezésre bocsátja a hazai és nemzetközi cirkuszművészeti és társművészeti alkotásokhoz és cirkusztörténeti kutatásokhoz szükséges nyomtatott és elektronikus dokumentumokat, valamint tárgyi emlékeket, mindezeken túl tartalomközvetítői és -előállítói szerepet egyaránt felvállal. Az intézmény kiveszi részét a cirkuszmüvészet népszerüsítéséből és folyamatosan lépést tart a felhasználói igényekkel. ${ }^{106}$

Az információs központ küldetésnyilatkozatából is látszik, hogy egy rendkívül speciális gyüjtőkörű, a megszokott közgyűjteményi tevékenységtől részben elétrő feladatokat ellátó intézmény kezdi bontogatni szárnyait, melynek megvalósulásáig még igen sok a tennivaló.

\footnotetext{
${ }^{106}$ Juhász Éva: Könyvtárgazda(g)ság: pénzügyi vonatkozású korszerű menedzsmenteljárások könyvtári alkalmazása. Témavezető: Kiszl Péter. Doktori disszertáció, 2019. Bp., ELTE BTK. 181-215. p. Forrás: https://doi.org/10.15476/ELTE.2018.193
} 
A cirkuszművészeti szakkönyvtár kialakításában hatékony segítséget nyújtanak/nyújthatnak - a gyakorló könyvtári szakemberek mellett - az ELTE Könyvtár- és Információtudományi Intézetének alap- és mesterképzésében tanuló informatikus könyvtáros hallgatói a kötelező szakmai gyakorlataik keretein belül. A hallgatók szemeszterenként előre meghatározott tematika alapján, a választott specializációtól függően teljesítik a gyakorlatok követelményeit. A követelményrendszer megfogalmazása lehetővé teszi, hogy az általánosan megfeleljen a különbözö könyvtártípusok jellemzőinek és adottságainak, az alább felsoroltakon belül azonban az egyes könyvtárak által biztosított gyakorlási lehetőségek/formák esetében mélységbeli, részletezettségbeli eltérések, speciális körülmények lehetnek. Az egymásra épülő szakmai gyakorlatok figyelembe veszik a hallgatók tanulmányi előmenetelét, aminek mentén végig követik az összes könyvtári tevékenységet, ezáltal nyújtva gyakorlati ismereteket a jövő könyvtáros szakembereinek. A formálódó cirkuszművészeti szakkönyvtárban megtalálhatóak mindazok a tevékenységek, melyeket a különböző képzési formában tanuló hallgatóknak - szakmai gyakorlataik keretein belül - teljesíteniük kell.

\section{A szakmai gyakorlatok menete}

A hallgató felveszi a kapcsolatot az intézmény vezetőjével és/vagy gyakorlatvezetőjével, majd tájékoztatja erről a szakmai gyakorlatot felügyelő oktatót a szorgalmi időszak kezdetétől számított 4. hét péntekéig. A gyakorlat részleteinek ismeretében a szakmai gyakorlatot felügyelő oktató felkérő levelet készít a fogadó intézmény számára, amely tartalmazza a gyakorlat körülményeit, követelményeit, valamint a gyakorlat tematikáját, óraszámát. A hallgató a gyakorlatot csak a felkérő levél megérkezése/átadása után kezdheti meg, ennek hiányában a gyakorlat érvénytelen.

A gyakornokot szakmai gyakorlata idején az intézmény által kijelölt gyakorlatvezető felügyeli, látja el feladatokkal és segíti a hatékony ismeretszerzésben. A gyakorlat végeztével a fogadó intézmény rövid összefoglaló értékelést készít a hallgató munkájáról, amellyel igazolja a gyakorlat teljesítését, megnevezi és értékeli a hallgató által elvégzett feladatokat, valamint javaslatot tesz a féléves gyakorlati érdemjegyre is. Az értékelés 5 fokozatú: elégtelen (1), elégséges (2), közepes (3), jó (4), jeles (5). A szöveges értékelésen kívül, az igazoláson fel kell tüntetni a hallgató nevét, a gyakorlat tantárgyi kódját, időtar- 
tamát (óraszám, időtartam). Az igazolást az intézményvezető és/vagy a gyakorlatvezető aláírása, valamint az intézmény bélyegzője hitelesíti. A gyakorlat teljesítéséről szóló igazolást a hallgatónak regisztrálás céljából a szakmai gyakorlat teljesítését követően, a szakmai gyakorlatok intézeti koordinátorának be kell mutatnia. A szakmai gyakorlat teljesítésének tényét és minősítését az egyetemi NEPTUN Egységes Tanulmányi Rendszerben rögzíteni kell.

A hallgató a gyakorlat befejezését követően, de legkésőbb a vizsgaidőszak utolsó előtti hetén péntekig leadja munkanaplóját, melyben a szakmai gyakorlat során szerzett tapasztalatait összegzi, részletesen beszámol a végzett tevékenységekről.

\section{A fogadó intézmény jogai és kötelezettségei a szakmai gyakorlatok lebonyolítása során}

Alapelvek:

- A fogadó intézmény az Egyetem hallgatóit az előzetesen egyeztetett időszakban fogadja szakmai gyakorlat céljából. A gyakorlatok a fogadó intézmény székhelyén vagy telephelyén zajlanak.

- A fogadó intézmény vállalja, hogy a hallgatókat tanulmányaiknak megfelelő, az Egyetem által előre, írásban jelzett szakterületen foglalkoztatja; biztosítja a gyakorlat lebonyolításához szükséges helyet, eszközöket, valamint a szükséges szakmai felügyeletet, irányítást.

- A fogadó intézmény köteles a hallgatók részére foglalkoztatásuk megkezdése előtt munkavédelmi oktatást tartani.

- A hallgatók napi foglalkoztatásának időtartama a nyolc (8) órát nem haladhatja meg.

- A szakmai gyakorlat teljesítését a fogadó intézmény az „Igazolás a gyakorlat teljesítéséről" nyomtatvány kitöltésével, aláírásával, továbbá a hallgató által a szakmai gyakorlatról készített írásos beszámoló szignálásával, és a „Munkahelyi vezetői értékelés” nyomtatvány kitöltésével és aláírásával igazolja. Az igazolást és a szignált beszámolót a hallgatónak kell átadni, míg az írásbeli értékelésből a hallgatónak és az Egyetemnek is át kell adni (meg kell küldeni) egy-egy példányt.

- Amennyiben a szakmai gyakorlat ideje alatt a foglalkoztatás valamely okból megszakad, úgy a fogadó intézmény a hallgató által teljesített 
időt igazolja és a szakmai gyakorlat megszakításának okát írásban, mind az Egyetemmel, mind a hallgatóval közli.

\section{A szakmai gyakorlatok részletei a különböző képzési formákban}

Az alapképzésben négy szakmai gyakorlatot kell teljesíteniük a hallgatóknak. Az első a gyüjteményszervezés, állományfejlesztés témakörét öleli fel, ami a kialakulóban lévő cirkuszművészeti szakkönyvtár esetében egy olyan terület, ahol hathatós segítséget nyújthatnak a gyakornokok.

A második gyakorlat témája a formai és tartalmi feltárás. A müfaji sajátosság miatt nagy a valószínűsége annak, hogy az NCK könyvtára által szerzeményezett dokumentumok jelentős része nem szerepel más hazai és külföldi könyvtárak katalógusaiban, ezért a formai és tartalmi feltárás helyben történik; erre a munkafolyamatra kiválóan alkalmazhatók a hallgatók.

A harmadik gyakorlat a könyvtári menedzsment, szolgáltatások szervezése feladatkörét járja körül. A korszerủ menedzsmentismeretekkel rendelkező hallgatók sokat segíthetnek a szárnyait bontogató intézmény arculatának kialakításában és az új, közösségi média alapú szolgáltatásainak bevezetésében.

A negyedik gyakorlat specializációspecifikus, hiszen míg Könyvtörténet specializáción az állományvédelem és digitalizáció a téma, addig az Információ- és tudásmenedzsment szakirányon a marketing és PR ismeretek gyakorlati elmélyítése a cél. Mindkettő olyan terület, amely egyaránt fontos napi feladata lesz a cirkuszmủvészeti szakkönyvtárnak.

Mesterképzésben két szakmai gyakorlat van. Az első témája az általános és szaktájékoztatás, illetve az olvasószolgálat, míg a másodiké az információs szolgáltatások szervezése és a szaktájékoztatás. Mindkét gyakorlat az olvasókkal való kapcsolattartást célozza. Mesterképzésben a hallgatók már rendelkeznek azokkal a kompetenciákkal, melyek ezeken a területeken kamatoztathatók.

A zenei könyvtáros képzésben tanuló hallgatók a cirkuszhoz köthető számtalan zenei produkció és azoknak tárgyi megnyilvánulásai (pl. kották) révén szintén szerepet vállalhatnak két szakmai gyakorlatuk keretein belül a könyvtár tevékenységében. A gyüjteményszervezés, állományfejlesztés 
témájú gyakorlaton segíthetnek a speciális zenei dokumentumok beszerzésében, feltárásában. Az általános és szaktájékoztatás, olvasószolgálat terén pedig a zenével kapcsolatos igények, kérések kiszolgálásában nyújthatnak szakmai segítséget.

A továbbiakban olvashatóak az Eötvös Loránd Tudományegyetem Bölcsészettudományi Kar Könyvtár- és Információtudományi Intézetének különböző képzési formáiban a szakmai gyakorlatra vonatkozó útmutatói.

\section{Útmutató}

az informatikus könyvtáros alapképzésben (BA)

nappali tagozaton teljesítendö

szakmai gyakorlatokhoz

Az útmutató az Eötvös Loránd Tudományegyetem informatikus könyvtáros alapképzésben (BA) résztvevő, nappali tagozatos hallgatói számára készült. Tartalmazza a 6 féléves képzési idő alatt teljesítendő könyvtári szakmai gyakorlatok legfontosabb jellemzőit, a tanegységek kódjait, óra- és kreditszámait, valamint a gyakorlatok megkezdéséhez szükséges tantárgyi előfeltételeket. A hallgató által választott specializációtól függően tájékoztat a gyakorlatok tematikájáról és a gyakorlati helyek kiválasztásának szempontjairól és feltételeiről. A szakzáróvizsgára bocsátás feltétele a tanegységlistában előírt szakmai gyakorlatok sikeres teljesítése.

\section{Alapképzés (BA) nappali tagozat}

\subsection{A szakmai gyakorlatok óra- és kreditszáma}

\begin{tabular}{|l|c|c|c|c|l|}
\hline Időpont & Kód & Tantárgy & $\begin{array}{c}\text { Óra } \\
\text { félév }\end{array}$ & Kredit & Követelmény \\
\hline 3. félév & BBN-IKT19-291 & Szakmai gyakorlat 1. & 80 & 4 & gyakorlati jegy \\
\hline 4. félév & BBN-IKT19-292 & Szakmai gyakorlat 2. & 80 & 4 & gyakorlati jegy \\
\hline 5. félév & BBN-IKT19-293 & Szakmai gyakorlat 3. & 80 & 4 & gyakorlati jegy \\
\hline
\end{tabular}


ÚTMUTATÓ KÖNYVTÁRALAPÍTÁSHOZ

\begin{tabular}{|l|l|l|l|l|l|}
\hline 6. félév & BBN-IKT19-294 & Szakmai gyakorlat 4. & 60 & 3 & gyakorlati jegy \\
\hline Összesen: 300 óra
\end{tabular}

${ }^{1}$ A feltüntetett óraszámok 45 perces óraként értendők.

\subsection{A gyakorlatok vázlatos tematikája}

A hallgatók szemeszterenként előre meghatározott tematika alapján, a választott specializációtól függően teljesítik a gyakorlatok követelményeit. A követelményrendszer megfogalmazása lehetővé teszi, hogy az általánosan megfeleljen a különböző könyvtártípusok jellemzőinek és adottságainak, így a felsoroltakon belül az egyes könyvtárak által biztosított gyakorlási lehetőségek/formák esetében mélységbeli, részletezettségbeli eltérések, speciális körülmények lehetnek.

\begin{tabular}{|l|l|l|l|}
\hline Időpont & \multicolumn{1}{|c|}{ Kód } & \multicolumn{1}{|c|}{ Tantárgy } & \multicolumn{1}{|c|}{ Tematika } \\
\hline 3. félév & BBN-IKT19-291 & Szakmai gyakorlat 1. & $\begin{array}{l}\text { Gyüjteményszervezés, } \\
\text { álományfejlesztés }\end{array}$ \\
\hline 4. félév & BBN-IKT19-292 & Szakmai gyakorlat 2. & Formai és tartalmi feltárás \\
\hline 5. félév & BBN-IKT19-293 & Szakmai gyakorlat 3. & $\begin{array}{l}\text { Könyvtári menedzsment, } \\
\text { szolgáltatások szervezése }\end{array}$ \\
\hline 6. félév & BBN-IKT19-294 & Szakmai gyakorlat 4. & $\begin{array}{l}\text { Információ- és tudásmenedzsment } \\
\text { specializáció: Marketing és PR } \\
\text { Könyvtörténeti specializáció: } \\
\text { Állományvédelem és digitalizáció }\end{array}$ \\
\hline
\end{tabular}




\subsection{A szakmai gyakorlatok tantárgyi előfeltételei}

Az alapképzésben a szakmai gyakorlatok időben egymásra épülnek, tantárgyi előfeltételei egymásnak, továbbá az elméleti képzés tematikájához igazodó tantárgyi előfeltételek is előfordulhatnak. Szakmai gyakorlatra az a hallgató bocsátható, aki a tantervben az adott szakmai gyakorlathoz rendelt előfeltétel(eke)t maradéktalanul teljesítette.

\begin{tabular}{|c|c|c|c|}
\hline Időpont & Kód & Tantárgy & $\begin{array}{c}\text { Elöfeltételként teljesítendő } \\
\text { tárgy(ak) }\end{array}$ \\
\hline 3. félév & BBN-IKT19-291 & Szakmai gyakorlat 1. & BBN-IKT-224 Könyvtártan \\
\hline \multirow{2}{*}{ 4. félév } & \multirow{2}{*}{ BBN-IKT19-292 } & \multirow{2}{*}{ Szakmai gyakorlat 2.} & $\begin{array}{l}\text { BBN-IKT19-203 Formai feltárás, } \\
\text { dokumentum-leírás } 3 .\end{array}$ \\
\hline & & & $\begin{array}{l}\text { BBN-IKT19-291 Szakmai gyakorlat } \\
1 .\end{array}$ \\
\hline \multirow{2}{*}{ 5. félév } & \multirow{2}{*}{ BBN-IKT19-293 } & \multirow{2}{*}{ Szakmai gyakorlat 3.} & $\begin{array}{l}\text { BBN-IKT19-226 Menedzsment } \\
\text { ismeretek }\end{array}$ \\
\hline & & & $\begin{array}{l}\text { BBN-IKT19-292 Szakmai gyakorlat } \\
2 .\end{array}$ \\
\hline \multirow{2}{*}{ 6. félév } & \multirow{2}{*}{ BBN-IKT19-294 } & \multirow{2}{*}{ Szakmai gyakorlat 4.} & $\begin{array}{l}\text { BBN-IKT19-SZD Egyéni } \\
\text { szakdolgozati felkészülés }\end{array}$ \\
\hline & & & $\begin{array}{l}\text { BBN-IKT19-293 Szakmai gyakorlat } \\
3 .\end{array}$ \\
\hline
\end{tabular}

\section{Útmutató}

az informatikus könyvtáros alapképzésben (BA)

levelező tagozaton teljesítendő szakmai gyakorlatokhoz

Az útmutató az Eötvös Loránd Tudományegyetem informatikus könyvtáros alapképzésben (BA) résztvevő, levelező tagozatos hallgatói számára készült. Tartalmazza a 6 féléves képzési idő alatt teljesítendő könyvtári szakmai gyakorlatok legfontosabb jellemzőit, a tanegységek kódjait, óra- és 


\section{ÚTMUTATÓ KÖNYVTÁRALAPÍTÁSHOZ}

kreditszámait, valamint a gyakorlatok megkezdéséhez szükséges tantárgyi előfeltételeket. A hallgató által választott specializációtól függően tájékoztat a gyakorlatok tematikájáról és a gyakorlati helyek kiválasztásának szempontjairól és feltételeiről. A szakzáróvizsgára bocsátás feltétele a tanegységlistában előírt szakmai gyakorlatok sikeres teljesítése.

\section{Alapképzés (BA) levelező tagozat}

\subsection{A szakmai gyakorlatok óra- és kreditszáma}

\begin{tabular}{|l|c|c|c|c|l|}
\hline Időpont & Kód & Tantárgy & $\begin{array}{c}\text { Óra }{ }^{1} / \\
\text { félév }\end{array}$ & Kredit & Követelmény \\
\hline 3. félév & BBN-IKT19-L-291 & Szakmai gyakorlat 1. & 45 & 4 & gyakorlati jegy \\
\hline 4. félév & BBN-IKT19-L-292 & Szakmai gyakorlat 2. & 45 & 4 & gyakorlati jegy \\
\hline 5. félév & BBN-IKT19-L-293 & Szakmai gyakorlat 3. & 45 & 4 & gyakorlati jegy \\
\hline 6. félév & BBN-IKT19-L-294 & Szakmai gyakorlat 4. & 45 & 3 & gyakorlati jegy \\
\hline Összesen: $\mathbf{1 8 0}$ óra & \multicolumn{2}{|l}{} \\
\hline
\end{tabular}

${ }^{1}$ A feltüntetett óraszámok 45 perces óraként értendők.

\subsection{A gyakorlatok vázlatos tematikája}

A hallgatók szemeszterenként előre meghatározott tematika alapján, a választott specializációtól függően teljesítik a gyakorlatok követelményeit. A követelményrendszer megfogalmazása lehetővé teszi, hogy az általánosan megfeleljen a különböző könyvtártípusok jellemzőinek és adottságainak, így a felsoroltakon belül az egyes könyvtárak által biztosított gyakorlási lehetőségek/formák esetében mélységbeli, részletezettségbeli eltérések, speciális körülmények lehetnek. 


\begin{tabular}{|l|c|l|l|}
\hline Időpont & \multicolumn{1}{|c|}{ Kód } & \multicolumn{1}{c|}{ Tantárgy } & \multicolumn{1}{c|}{ Tematika } \\
\hline 3. félév & IKT19-L-291 & Szakmai gyakorlat 1. & $\begin{array}{l}\text { Gyüjteményszervezés, } \\
\text { állományfejlesztés }\end{array}$ \\
\hline 4. félév & IKT19-L-292 & Szakmai gyakorlat 2. & Formai és tartalmi feltárás \\
\hline 5. félév & IKT19-L-293 & Szakmai gyakorlat 3. & $\begin{array}{l}\text { Könyvtári menedzsment, } \\
\text { szolgáltatások szervezése }\end{array}$ \\
\hline 6. félév & IKT19-L-294 & Szakmai gyakorlat 4. & $\begin{array}{l}\text { Információ- és tudásmenedzsment } \\
\text { specializáció: Marketing és PR } \\
\text { Könyvtörténeti specializáció: } \\
\text { Állományvédelem és digitalizáció }\end{array}$ \\
\hline
\end{tabular}

\subsection{A szakmai gyakorlatok tantárgyi előfeltételei}

Az alapképzésben a szakmai gyakorlatok időben egymásra épülnek, tantárgyi előfeltételei egymásnak, továbbá az elméleti képzés tematikájához igazodó tantárgyi előfeltételek is előfordulhatnak. Szakmai gyakorlatra az a hallgató bocsátható, aki a tantervben az adott szakmai gyakorlathoz rendelt előfeltétel(eke)t maradéktalanul teljesítette.

\begin{tabular}{|l|l|l|l|}
\hline Időpont & Kód & \multicolumn{1}{|c|}{ Tantárgy } & Előfeltételként teljesítendő tárgy(ak) \\
\hline 3. félév & IKT19-L-291 & Szakmai gyakorlat 1. & IKT19-L-224 Könyvtártan \\
\hline 4. félév & IKT19-L-292 & Szakmai gyakorlat 2. & $\begin{array}{l}\text { IKT19-L-203 Formai feltárás, } \\
\text { dokumentum-leírás 3. }\end{array}$ \\
\cline { 3 - 5 } & & IKT19-L-291Szakmai gyakorlat 1. \\
\hline
\end{tabular}




\begin{tabular}{|l|l|l|l|}
\hline 5. félév & IKT19-L-293 & Szakmai gyakorlat 3. & IKT19-L-226 Menedzsment ismeretek \\
\cline { 4 - 5 } & & & IKT19-L-292 Szakmai gyakorlat 2. \\
\hline 6. félév & IKT19-L-294 & Szakmai gyakorlat 4. & IKT19-L-293 Szakmai gyakorlat 3. \\
\hline
\end{tabular}

\section{Útmutató}

\section{a könyvtártudomány mesterképzésben (MA) nappali tagozaton teljesítendő szakmai gyakorlatokhoz}

Az útmutató az Eötvös Loránd Tudományegyetem könyvtártudomány mesterképzésben (MA) résztvevő, nappali tagozatos hallgatói számára készült. Tartalmazza a 4 féléves képzési idő alatt teljesítendő könyvtári szakmai gyakorlatok legfontosabb jellemzőit, a tanegységek kódjait, óra- és kreditszámait, valamint a gyakorlatok megkezdéséhez szükséges tantárgyi előfeltételeket. Tájékoztat továbbá a gyakorlatok tematikájáról és a gyakorlati helyek kiválasztásának szempontjairól és feltételeiről. A szakzáróvizsgára bocsátás feltétele a tanegységlistában előírt szakmai gyakorlatok sikeres teljesítése.

\section{Mesterképzés (MA) nappali tagozat}

\subsection{A szakmai gyakorlatok óra- és kreditszáma}

\begin{tabular}{|l|c|c|c|c|l|}
\hline Időpont & Kód & Tantárgy & $\begin{array}{c}\text { Óra }^{1} / \\
\text { félév }\end{array}$ & Kredit & Követelmény \\
\hline 2. félév & BMA-IKTD-201 & Szakmai gyakorlat 1. & 60 & 4 & gyakorlati jegy \\
\hline 3. félév & BMA-IKTD-202 & Szakmai gyakorlat 2. & 90 & 6 & gyakorlati jegy \\
\hline Összesen: 150 óra
\end{tabular}

${ }^{1}$ A feltüntetett óraszámok 45 perces óraként értendők. 


\subsection{A gyakorlatok vázlatos tematikája}

A hallgatók szemeszterenként előre meghatározott tematika alapján teljesítik a gyakorlatok követelményeit. A követelményrendszer megfogalmazása lehetővé teszi, hogy az általánosan megfeleljen a különböző könyvtártípusok jellemzőinek és adottságainak, így a felsoroltakon belül az egyes könyvtárak által biztosított gyakorlási lehetőségek/formák esetében mélységbeli, részletezettségbeli eltérések, speciális körülmények lehetnek.

\begin{tabular}{|l|c|c|l|}
\hline Időpont & Kód & \multicolumn{1}{|c|}{ Tantárgy } & \multicolumn{1}{c|}{ Tematika } \\
\hline 2. félév & BMA-IKTD-201 & Szakmai gyakorlat 1. & $\begin{array}{l}\text { Általános és szaktájékoztatás, } \\
\text { olvasószolgálat }\end{array}$ \\
\hline 3. félév & BMA-IKTD-202 & Szakmai gyakorlat 2. & $\begin{array}{l}\text { Információs szolgáltatások } \\
\text { szervezése, szaktájékoztatás }\end{array}$ \\
\hline
\end{tabular}

\subsection{A szakmai gyakorlatok tantárgyi előfeltételei}

A mesterképzésben a szakmai gyakorlatok időben egymásra épülnek, tantárgyi előfeltételei egymásnak. Szakmai gyakorlatra az a hallgató bocsátható, aki a tantervben az adott szakmai gyakorlathoz rendelt előfeltételt maradéktalanul teljesítette.

\begin{tabular}{|l|c|c|c|}
\hline Időpont & Kód & Tantárgy & $\begin{array}{c}\text { Előfeltételként teljesítendő } \\
\text { tárgy(ak) }\end{array}$ \\
\hline 2. félév & BMA-IKTD-201 & Szakmai gyakorlat 1. & - \\
\hline 3. félév & BMA-IKTD-202 & Szakmai gyakorlat 2. & $\begin{array}{l}\text { BMA-IKTD-201 Szakmai } \\
\text { gyakorlat 1. }\end{array}$ \\
\hline
\end{tabular}




\section{Útmutató}

a könyvtártudomány mesterképzésben (MA)

levelező tagozaton teljesítendő

szakmai gyakorlatokhoz

Az útmutató az Eötvös Loránd Tudományegyetem könyvtártudomány mesterképzésben (MA) résztvevő, levelező tagozatos hallgatói számára készült. Tartalmazza a 4 féléves képzési idő alatt teljesítendő könyvtári szakmai gyakorlatok legfontosabb jellemzőit, a tanegységek kódjait, óraés kreditszámait, valamint a gyakorlatok megkezdéséhez szükséges tantárgyi előfeltételeket. Tájékoztat továbbá a gyakorlatok tematikájáról és a gyakorlati helyek kiválasztásának szempontjairól és feltételeiről. A szakzáróvizsgára bocsátás feltétele a tanegységlistában előírt szakmai gyakorlatok sikeres teljesítése.

\section{Mesterképzés (MA) levelező tagozat}

\subsection{A szakmai gyakorlatok óra- és kreditszáma}

\begin{tabular}{|l|c|c|c|c|c|}
\hline Időpont & Kód & Tantárgy & $\begin{array}{c}\text { Óra }{ }^{1} / \\
\text { félév }\end{array}$ & Kredit & Követelmény \\
\hline 2. félév & BMA-IKTD19-L-201 & Szakmai gyakorlat 1. & 45 & 4 & gyakorlati jegy \\
\hline 3. félév & BMA-IKTD19-L-202 & Szakmai gyakorlat 2. & 45 & 6 & gyakorlati jegy \\
\hline Összesen: 90 óra
\end{tabular}

${ }^{1}$ A feltüntetett óraszámok 45 perces óraként értendők.

\subsection{A gyakorlatok vázlatos tematikája}

A hallgatók szemeszterenként előre meghatározott tematika alapján teljesítik a gyakorlatok követelményeit. A követelményrendszer megfogalmazása lehetővé teszi, hogy az általánosan megfeleljen a különböző könyvtártípusok jellemzőinek és adottságainak, így a felsoroltakon belül az egyes 
könyvtárak által biztosított gyakorlási lehetőségek/formák esetében mélységbeli, részletezettségbeli eltérések, speciális körülmények lehetnek.

\begin{tabular}{|l|c|l|l|}
\hline Időpont & \multicolumn{1}{|c|}{ Kód } & \multicolumn{1}{|c|}{ Tantárgy } & \multicolumn{1}{c|}{ Tematika } \\
\hline 2. félév & BMA-IKTD19-L-201 & Szakmai gyakorlat 1. & $\begin{array}{l}\text { Általános és szaktájékoztatás, } \\
\text { olvasószolgálat }\end{array}$ \\
\hline 3. félév & BMA-IKTD19-L-202 & Szakmai gyakorlat 2. & $\begin{array}{l}\text { Információs szolgáltatások } \\
\text { szervezése, szaktájékoztatás }\end{array}$ \\
\hline
\end{tabular}

\subsection{A szakmai gyakorlatok tantárgyi előfeltételei}

A mesterképzésben a szakmai gyakorlatok időben egymásra épülnek, tantárgyi előfeltételei egymásnak. Szakmai gyakorlatra az a hallgató bocsátható, aki a tantervben az adott szakmai gyakorlathoz rendelt elöfeltételt maradéktalanul teljesítette.

\begin{tabular}{|l|c|c|c|}
\hline Időpont & \multicolumn{1}{|c|}{ Kód } & \multicolumn{1}{|c|}{ Tantárgy } & $\begin{array}{c}\text { Előfeltételként teljesítendő } \\
\text { tárgy(ak) }\end{array}$ \\
\hline 2. félév & BMA-IKTD19-L-201 & Szakmai gyakorlat 1. & \\
\hline 3. félév & BMA-IKTD19-L-202 & Szakmai gyakorlat 2. & $\begin{array}{l}\text { BMA-IKTD-201 Szakmai } \\
\text { gyakorlat 1. }\end{array}$ \\
\hline
\end{tabular}

\section{Útmutató}

a zenekultúra alapszak - zenei könyvtáros specializáció képzésben (BA) nappali tagozaton teljesítendő szakmai gyakorlatokhoz

Az útmutató az Eötvös Loránd Tudományegyetem zenekultúra alapszak zenei könyvtáros specializáció képzésben (BA) résztvevő, nappali tagozatos hallgatói számára készült. Tartalmazza a 6 féléves képzési idő alatt teljesítendő könyvtári szakmai gyakorlatok legfontosabb jellemzőit, a tanegységek 


\section{ÚTMUTATÓ KÖNYVTÁRALAPÍTÁSHOZ}

kódjait, óra- és kreditszámait, valamint a gyakorlatok megkezdéséhez szükséges tantárgyi előfeltételeket. A hallgató által választott specializációtól függően tájékoztat a gyakorlatok tematikájáról és a gyakorlati helyek kiválasztásának szempontjairól és feltételeiről. A szakzáróvizsgára bocsátás feltétele a tanegységlistában elöírt szakmai gyakorlatok sikeres teljesítése.

\section{Alapképzés (BA) nappali tagozat}

\subsection{A szakmai gyakorlatok óra- és kreditszáma}

\begin{tabular}{|l|l|l|c|c|c|}
\hline Időpont & \multicolumn{1}{|c|}{ Kód } & Tantárgy & $\begin{array}{c}\text { Óra } / \\
\text { félév }\end{array}$ & Kredit & Követelmény \\
\hline 4. félév & BBN-ZKS-061 & $\begin{array}{l}\text { Zenei könyvtári } \\
\text { gyakorlat 1. }\end{array}$ & 40 & 2 & gyakorlati jegy \\
\hline 5. félév & BBN-ZKS-062 & $\begin{array}{l}\text { Zenei könyvtári } \\
\text { gyakorlat 2. }\end{array}$ & 40 & 2 & gyakorlati jegy \\
\hline Összesen: 80 óra
\end{tabular}

${ }^{1}$ A feltüntetett óraszámok 45 perces óraként értendők.

\subsection{A gyalkorlatok vázlatos tematikája}

A hallgatók szemeszterenként előre meghatározott tematika alapján, a választott specializációtól függően teljesítik a gyakorlatok követelményeit. A követelményrendszer megfogalmazása lehetővé teszi, hogy az általánosan megfeleljen a különböző könyvtártípusok jellemzőinek és adottságainak, így a felsoroltakon belül az egyes könyvtárak által biztosított gyakorlási lehetőségek/formák esetében mélységbeli, részletezettségbeli eltérések, speciális körülmények lehetnek. 


\begin{tabular}{|l|c|c|l|}
\hline Időpont & \multicolumn{1}{|c|}{ Kód } & \multicolumn{1}{|c|}{ Tantárgy } & \multicolumn{1}{|c|}{ Tematika } \\
\hline 4. félév & BBN-ZKS-061 & Zenei könyvtári gyakorlat 1. & $\begin{array}{l}\text { Gyújteményszervezés, } \\
\text { állományfejlesztés }\end{array}$ \\
\hline 5. félév & BBN-ZKS-062 & Zenei könyvtári gyakorlat 2. & $\begin{array}{l}\text { Általános és szaktájékoztatás, } \\
\text { olvasószolgálat }\end{array}$ \\
\hline
\end{tabular}

\subsection{A szakmai gyakorlatok tantárgyi elöfeltételei}

Az alapképzésben a szakmai gyakorlatok időben egymásra épülnek, tantárgyi előfeltételei egymásnak, továbbá az elméleti képzés tematikájához igazodó tantárgyi előfeltételek is előfordulhatnak. Szakmai gyakorlatra az a hallgató bocsátható, aki a tantervben az adott szakmai gyakorlathoz rendelt előfeltétel(eke)t maradéktalanul teljesítette.

\begin{tabular}{|l|c|c|c|}
\hline Időpont & Kód & Tantárgy & $\begin{array}{c}\text { Előfeltételként teljesítendö } \\
\text { tárgy(ak) }\end{array}$ \\
\hline 4. félév & BBN-ZKS-061 & Zenei könyvtári gyakorlat 1. & - \\
\hline 5. félév & BBN-ZKS-062 & Zenei könyvtári gyakorlat 2. & $\begin{array}{l}\text { BBN-ZKS-061 Zenei } \\
\text { könyvtári gyakorlat 1. }\end{array}$ \\
\hline
\end{tabular}

\section{Útmutató}

a zenekultúra alapszak - zenei könyvtáros specializáció képzésben (BA) levelező tagozaton teljesítendő szakmai gyakorlatokhoz

Az útmutató az Eötvös Loránd Tudományegyetem zenekultúra alapszak zenei könyvtáros specializáció képzésben (BA) résztvevő, levelező tagozatos hallgatói számára készült. Tartalmazza a 6 féléves képzési idő alatt teljesítendő könyvtári szakmai gyakorlatok legfontosabb jellemzőit, a tanegységek kódjait, óra- és kreditszámait, valamint a gyakorlatok megkezdéséhez szükséges tantárgyi előfeltételeket. A hallgató által választott specializációtól függően tájékoztat a gyakorlatok tematikájáról és a gyakorlati helyek kivá- 


\section{ÚTMUTATÓ KÖNYVTÁRALAPÍTÁSHOZ}

lasztásának szempontjairól és feltételeiről. A szakzáróvizsgára bocsátás feltétele a tanegységlistában előírt szakmai gyakorlatok sikeres teljesítése.

\section{Alapképzés (BA) levelező tagozat}

\subsection{A szakmai gyakorlatok óra- és kreditszáma}

\begin{tabular}{|l|l|l|c|c|c|}
\hline Időpont & \multicolumn{1}{|c|}{ Kód } & Tantárgy & $\begin{array}{c}\text { Óra }{ }^{1} / \\
\text { félév }\end{array}$ & Kredit & Követelmény \\
\hline 4. félév & BBN-ZKS-L-061 & $\begin{array}{l}\text { Zenei könyvtári } \\
\text { gyakorlat 1. }\end{array}$ & 40 & 2 & gyakorlati jegy \\
\hline 5. félév & BBN-ZKS-L-062 & $\begin{array}{l}\text { Zenei könyvtári } \\
\text { gyakorlat 2. }\end{array}$ & 40 & 2 & gyakorlati jegy \\
\hline
\end{tabular}

\section{Összesen: 80 óra}

${ }^{1} \mathrm{~A}$ feltüntetett óraszámok 45 perces óraként értendők.

\subsection{A gyakorlatok vázlatos tematikája}

A hallgatók szemeszterenként előre meghatározott tematika alapján, a választott specializációtól függően teljesítik a gyakorlatok követelményeit. A követelményrendszer megfogalmazása lehetővé teszi, hogy az általánosan megfeleljen a különböző könyvtártípusok jellemzőinek és adottságainak, így a felsoroltakon belül az egyes könyvtárak által biztosított gyakorlási lehetőségek/formák esetében mélységbeli, részletezettségbeli eltérések, speciális körülmények lehetnek.

\begin{tabular}{|l|l|l|l|}
\hline Időpont & Kód & Tantárgy & Tematika \\
\hline 4. félév & BBN-ZKS-L-061 & $\begin{array}{l}\text { Zenei könyvtári } \\
\text { gyakorlat 1. }\end{array}$ & $\begin{array}{l}\text { Gyüjteményszervezés, } \\
\text { állományfejlesztés }\end{array}$ \\
\hline 5. félév & BBN-ZKS-L-062 & $\begin{array}{l}\text { Zenei könyvtári } \\
\text { gyakorlat 2. }\end{array}$ & $\begin{array}{l}\text { Általános és szaktájékoztatás, } \\
\text { olvasószolgálat }\end{array}$ \\
\hline
\end{tabular}


SZAKMAI GYAKORLAT ÉRTÉKELŐLAP

\begin{tabular}{|c|c|c|c|c|c|}
\hline \multicolumn{2}{|l|}{ GYAKORLÓHELY NEVE: } & \multicolumn{4}{|c|}{$\begin{array}{l}\text { HALLGATÓ NEVE: } \\
\text { Szak/specializáció: }\end{array}$} \\
\hline \multicolumn{2}{|l|}{ Munkahelyi konzulens neve: } & \multicolumn{4}{|c|}{ Egyetemi konzulens neve: } \\
\hline \multicolumn{6}{|c|}{ A hallgató által elvégzett feladat(ok) rövid leírása: } \\
\hline \multirow{2}{*}{$\begin{array}{l}\text { Az elvégzett munka értékelésének } \\
\text { szempontjai: }\end{array}$} & \multicolumn{5}{|c|}{ Kérjük, jelölje be (x) a megfelelö rovatot! } \\
\hline & kiváló & jó & közepes & megfelelö & $\begin{array}{c}\text { nem } \\
\text { megfelelö }\end{array}$ \\
\hline \multicolumn{6}{|l|}{ 1. A munka iránti érdeklődése } \\
\hline \multicolumn{6}{|l|}{ 2. Kezdeményezőkészség } \\
\hline \multicolumn{6}{|l|}{ 3. Felfogóképesség } \\
\hline \multicolumn{6}{|l|}{ 4. Pontosság } \\
\hline \multicolumn{6}{|l|}{ 5. A végzett munka minősége } \\
\hline \multicolumn{6}{|l|}{ 6. Önálló véleményalkotás } \\
\hline \multicolumn{6}{|l|}{ 7. Építő ötletek } \\
\hline $\begin{array}{l}\text { 8. Csoportszellem (munkahelyi } \\
\text { beilleszkedés) }\end{array}$ & & & & & \\
\hline
\end{tabular}




\section{ÚTMUTATÓ KÖNYVTÁRALAPÍTÁSHOZ}

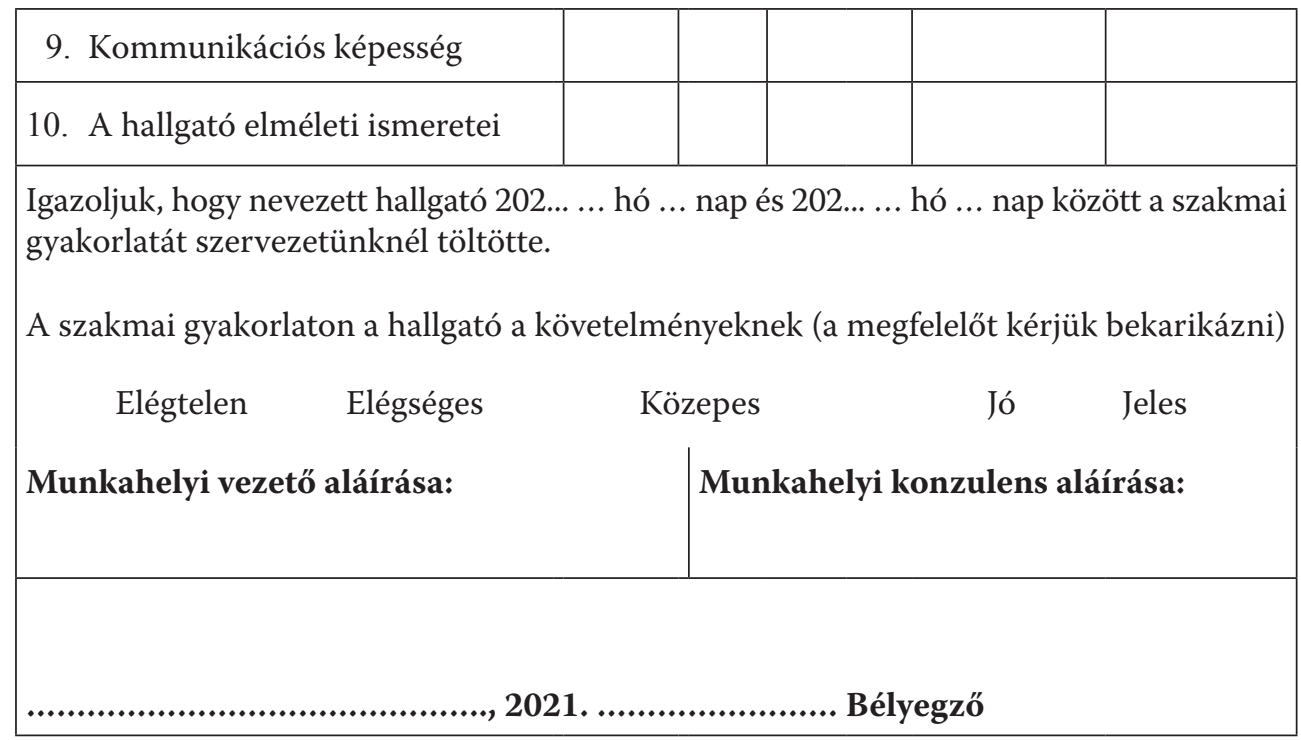

